U.S. DEPARTMENT OF ENERGY

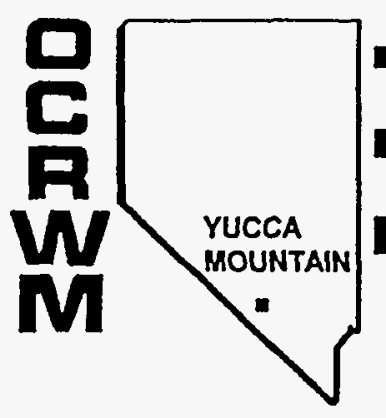

YUCCA MOUNTAIN

SITE CHARACTERIZATION

\title{
YUCCA MOUNTAIN \\ SITE CHARACTERIZATION PROJECT \\ TECHNICAL DATA \\ CATALOG \\ (QUARTERLY SUPPLEMENT)
}
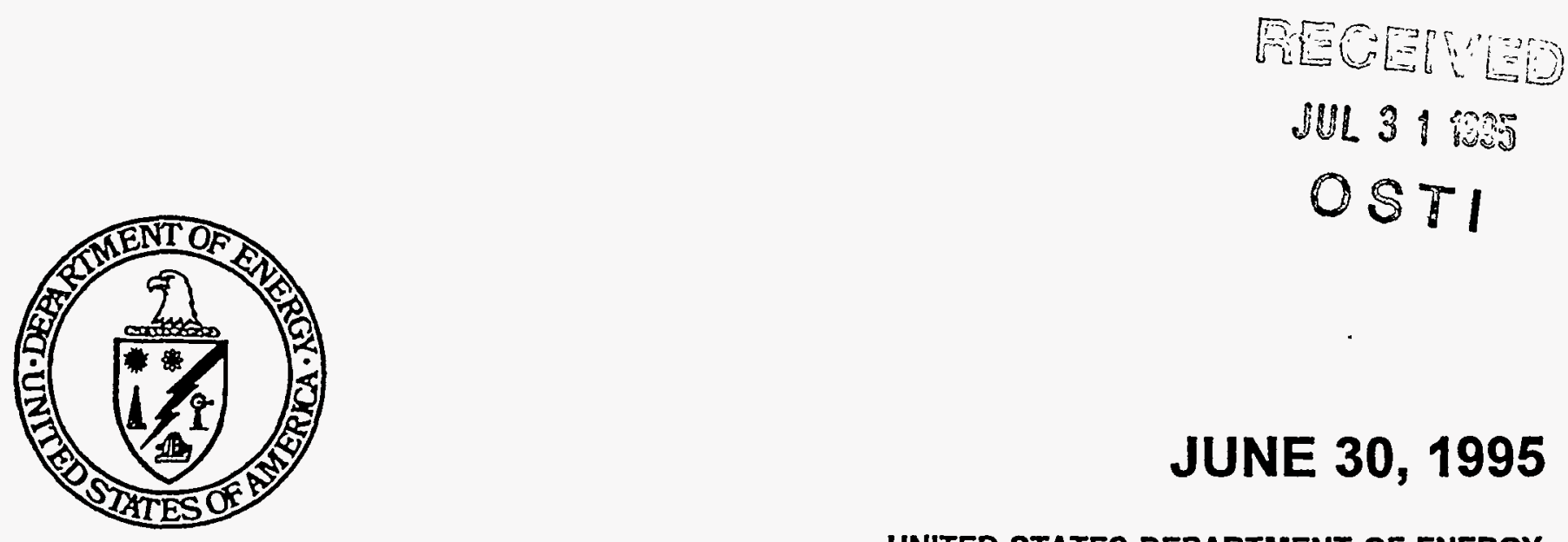

JUNE 30, 1995 


\title{
YUCCA MOUNTAIN \\ SITE CHARACTERIZATION PROJECT
}

\author{
TECHNICALDATA CATALOG \\ (QUARTERLY SUPPLEMENT)
}

\section{JUNE 30, 1995}

Available to DOE and DOE contractors from the:

Office of Scientific and Technical Information

P.O. Box 62

Oak Ridge, Tennessee 37831

Prices available from (615) 576-8401

Available to public from the:

National Technical Information Service

U.S. Department of Commerce

5285 Port Royal Rd.

Springfield, VA 22161

Distribution Category: UC-814

DISTRIBUTION OF THIS DOCUMENT IS UNLIMITED 
TABLE OF CONTENTS

\section{PAGE}

INTRODUCTION

ENVIRONMENTAL MONITORING AND MITIGATION PLAN . . . . . . . . 4

METEOROLOGICAL MONITORING PLAN • . . . . . . . . . . . . . . 5

PERFORMANCE ASSESSMENT MANAGEMENT PLAN • . • • • • . . . . . 6

RADIOLOGICAL MONITORING PLAN . . . . . . . . . . . . . . . . 7

SITE CHARACTERIZATION PROGRAM BASELINE • . . . . . . • . . . 17

SOCIOECONOMIC PLAN • . . . . . . . . . . . . . . . . . . . 138

REFERENCE INFORMATION BASE. • . . . . . . . . . . . . . . 139

APPENDIX A: SITE CHARACTERIZATION PROGRAM BASELINE

APPENDIX B: GEOGRAPHIC NODAL INFORMATION STUDY AND

EVALUATION SYSTEM (GENISES) ADDITIONS:

3RD QUARTER, FY 1995 . . . . . . . . . . . B-1

APPENDIX C: SUPERSEDING DATA ITEMS . . . . . . . . . . . . . C-1

DISTRIBUTION LIST

\section{DISCLAIMER}

This report was prepared as an account of work sponsored by an agency of the United States Government. Neither the United States Government nor any agency thereof, nor any of their employees, makes any warranty, express or implied, or assumes any legal liability or responsibility for the accuracy, completeness, or usefulness of any information, apparatus, product, or process disclosed, or represents that its use would not infringe privately owned rights. Reference herein to any specific commercial product, process, or service by trade name, trademark, manufacturer, or otherwise does not necessarily constitute or imply its endorsement, recommendation, or favoring by the United States Government or any agency thereof. The views and opinions of authors expressed herein do not necessarily state or reflect those of the United States Government or any agency thereof. 


\section{DISCLAIMER}

Portions of this document may be illegible in electronic image products. Images are produced from the best available original document. 


\section{INTRODUCTION}

The Department of Energy (DOE)/Nuclear Regulatory Commission (NRC) Site-Specific Procedural Agreement for Geologic Repository Site Investigation and Characterization Program requires the DOE to develop and maintain a catalog of data which will be updated and provided to the NRC at least quarterly. This catalog is to include a description of the data; the time (date), place, and method of acquisition; and where the data may be examined. The Yucca Mountain Site Characterization Project (YMP) Technical Data Catalog is published and distributed in accordance with the requirements of the Site-Specific Agreement.

The YMP Technical Data Catalog is a report based on reference information contained in the YMP Automated Technical Data Tracking system (ATDT). The reference information is provided by Participants for data acquired or developed in support of the YMP. The Technical Data Catalog is updated quarterly and distributed in the month following the end of each quarter. A complete revision to the catalog is published at the end of each fiscal year. Supplements to the end-of-year edition are published each quarter. These supplements provide information related to new data items not included in previous quarterly updates and data items affected by changes to previously published reference information. The Technical.Data Catalog, dated September 30, 1994, should be retained as the baseline document for the supplements until the end-of-year revision is published and distributed in October 1995.

Requests for data referenced in the Technical Data Catalog must be submitted in writing to the YMP Project Manager, Wesley $E$. Barnes, at the following address:

U.S. Department of Energy

Yucca Mountain Site Characterization Office P.O. Box 98608

Las Vegas, NV 89193-8608

Requests should reference the Data Tracking Number (DTN) used to identify each data item included in the Technical Data Catalog and should include the following information: the requester's name, organization, address, and telephone number; the scope of the data requested; a description of the intended use of the data; and any special format preferences. In response to specific requests, the YMP will provide the solicited technical data or information regarding where the data may be examined. 
The information contained in the Technical Data Catalog is organized by the governing plan under which the referenced technical data were acquired or developed. The applicable governing plans are identified in the table of contents. Site Characterization Program Baseline (SCPB) data items referenced in the catalog are further grouped by SCPB Activity Number. The catalog also includes a section that identifies data items available in the YMP Reference Information Base (RIB).

The Technical Data Catalog format includes the following information for each referenced data item:

(1) Data Tracking Number - Unique identifier for the referenced data item.

(2) Data Title/Descriotion - A brief description of the referenced data item.

(3) Acquisition/Development Period - The date or range of dates during which the referenced data item was acquired or developed.

(4) Acquisition/Development Iocation - The field or laboratory location where the referenced data item was acquired or developed.

(NOTE: Locations are identified by unique names/identifiers or coordinates. Locations identified by coordinates may be expressed in geographic, Nevada state plane, or Universal Transverse Mercator (UTM). Nevada state plane coordinates are indicated by an "(N)" at the end of each coordinate; UTM coordinates are indicated by a "(U)".)

(5) Acquisition/Development Method - A brief description of the method used and/or the procedure followed to acquire or develop the referenced data item.

(6) Data Trpe - An "A" for acquired data or a " $D$ " for developed data.

(7) Qualified - A " $Y$ " for Yes or an " $N$ " for No indicating whether or not the referenced data item was acquired or developed in accordance with an NRC accepted quality assurance program or qualified in accordance with appropriate YMP procedures.

(NOTE: Developed data items derived from other data sources are not classified as "Qualified" unless the identified data sources are also qualified.) 
(8) Data Location - A "P" indicates that the data reside in, and may be examined only at, a Participant Data Archive. A "C" indicates that the data are in, and may be examined at, the Central Records Facility (CRF). A "T" indicates that the data are in the YMP Technical Data Base Geographic Nodal Information Study and Evaluation System (GENISES). An "R" indicates that the data are in the RIB. Data items, which are indicated to be in the GENISES or RIB, may also be examined in the CRF.

New data items, which were not included in a previous quarterly edition of the Technical Data Catalog, are identified by an asterisk (*) preceding the DTN. Changes to reference information published in a previous edition of the catalog are identified by a double asterisk $(* *)$ preceding the DTN for each affected data item.

Appendix $A$ of this document lists the activity numbers and titles of all SCPB related data items referenced in the catalog. Appendix B identifies additions that were incorporated into the GENISES data base during the current quarter. Appendix $C$ identifies superseding data items. 
ENVIRONMENTAL MONITORING AND MITIGATION PLAN

DATA TRACKING NO.

*GS950600121347.001 DEPTH-TO-WATER DATA, DISCHARGE DATA AND BAROMETRIC PRESSURE DATA FROM WELL JF-3, $2 / 24 / 92-3 / 12 / 92$

ACQN/DEVL LOCATION : OE-25 JF3

*GS950600121347.002 DEPTH-TO-WATER DATA AND BAROMETRIC
PRESSORE DATA FROM
$12 / 17 / 91-5 / 12 / 92$.

ACQN/DEVL LOCATION : UE-25 J\#12

\section{PRESSORE DATA FROM WEIL OE-25 J\#12}

ACON/DEVL PERIOD

ACON/DEVL METHOD

02/24/92-03/12/92 HP-54,R0, "WATER-FLOW MEASUREMENTS USING 90-DEGREE V-NOTCH WEIRS, FLOMES AND BARRELS," HP-60,R1, "METHOD FOR MONITORING WATER LEVEL CHANGES OSING PRESSURE TRANSDOCERS," HP-99,R1, "INSTROCTION FOR THE OPERATION OF A WELL SOUNDER FOR MEASURING WATER LEVELS," AND HP-172, R0 "WATER LEVEI MEASUREMENT USING A TEN-TURN POTENTIOMETER."

HP-60,R1, "METHOD FOR MONITORING WATER LEVEI CHANGES USING PRESSURE TRANSDUCERS," AND HP-99, R1, "INSTROCTION FOR OPERATION OF A WELI SOONDER FOR MEASURING WATER LEVEIS." 
METEOROLOGICAI MONITORING PLAN

DATA TRACKING NO.

TITIE/DESCRIPTION

$\star \star T M 000000000001.059$ AMBIENT AIR MONITORING REPORT, JOLY SERTEMBER 1994

ACQN/DEVI LOCATION : YOCCA MOUNTAIN SITE AREA

**TM000000000001.062 ORIGINAL SOORCE HARDCOPY DATA FOR:

ATMOSPHERIC RRESSURE; PRECIPITATION

QDANTITY; RELATIVE HUMIDITY;

TEMPERATORE; WIND DIRECTION; AND WIND

SREED

ACQN/DEVI LOCATION : YUCCA MOUNTAIN SITE AREA

*TM000000000001.064 ORIGINAI SOURCE DATA FOR: ATMOSPHERIC PRESSURE, PRECIPITATION QUANTITY, RELATIVE HOMIDITY, TEMPERATORE, WIND SPEED, AND WIND DIRECTION

ACQN/DEVI LOCATION : YUCCA MOUNTAIN SITE AREA

*TM000000000001.065 VALIDATED METEOROLOGICAL DATA

ACQN/DEVL LOCATION : YUCCA MOUNTAIN SITE AREA
$01 / 01 / 95-03 / 31 / 95$

ACON/DEVT, PERIOD

ACQN/DEVL METHOD

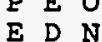

REFORMATTING OF DATA FROM ON-SITE DATALOGGERS

D Y C

$01 / 01 / 93-12 / 31 / 93$

DATA ACQOIRED FROM ON-SITE DATALOGGERS

01/01/95-03/31/95 DATA ACQUIRED FROM ON-SITE DATALOGGERS

A Y P

OBJECTIVE PROGRAM SCANNING, SUPPLEMENTED BY PROFESSIONAI JUDGEMENT 
PERFORMANCE ASSESSMENT MANAGEMENT PLAN

DATA TRACKING NO.

$\star \star$ SNL15041284001.001 HYDROLOGIC MECHANISMS GOVERNING FLUID
FLOW IN A PARTIAIIY SATURATED,
FRACTORED, POROOS MEDIUM.

ACQN/DEVL LOCATION : LAWRENCE BERKELEY LABORATORY
LOGBOOK FOR INVESTIGATION OF FRACTORE-MATRIX INTERACTION IN THE TOPOPAH SPRING TUFF.
ACQN/DEVI, PERIOD

$10 / 01 / 84-12 / 01 / 85$

SPRI ICAL RESULTS ARE FROM THE TOPOPAH SPRING MEMBER OF YOCCA MOUNTAIN, NEVADA BY TERISTICS, SPACINGS, AND

FROM MEASOREMENTS OF TUFF SAMPIES FROM THAT

LOCATION.

ACQN/DEVL LOCATION : SANDIA NATIONAL LABORATORIES, ALBUQUERQUE, NM

TEST X-RAY VISUALIZATION TECHNIQOES FOR FRACTURE FLOW AND IMBIBITION IN A ROCK MASS. 


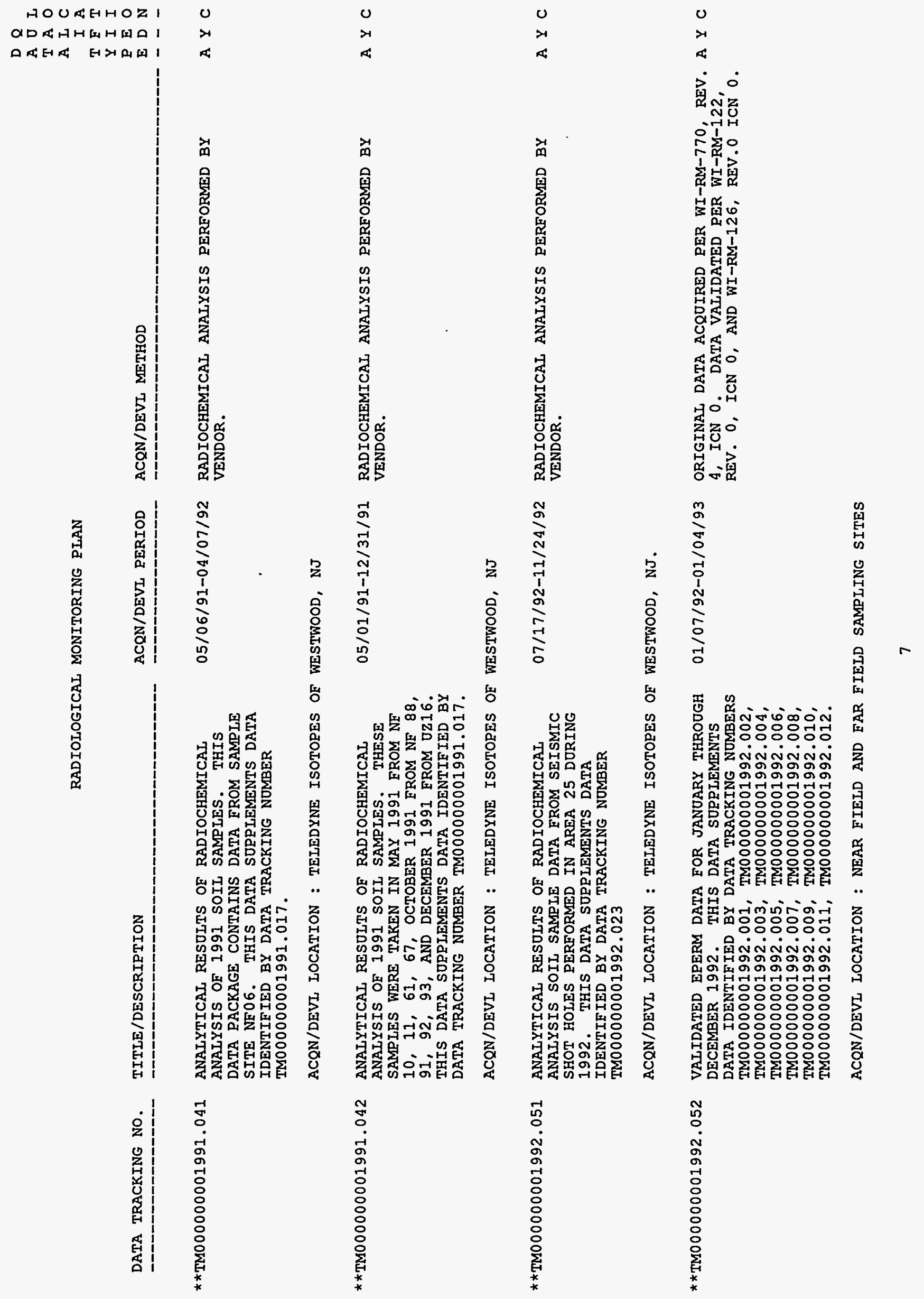


RADIOLOGICAL MONITORING PLAN

DATA TRACKING NO.

TITLE/DESCRIPTION

*TM000000001992.059 ANALYTICAL RESULTS OF RADIOCHEMICAI ANALYSIS OF 1991 \& 1992 SOIL SAMPLES. THESE SOIL SAMPLES WERE OBTAINED 0591 AT NF $67 ; 0292$ AT SS513; 1092 AT BORROW PIT R25B10; 1192 AT SS515 \& SS517; 1292 AT

NF 108; 0393 AT SS511. THIS DATA

SOPPLEMENTS DATA IDENTIFIED BY DATA

TRACKING NOMBER TMO000000001991.017.

ACQN/DEVL LOCATION : TELEDYNE ISOTOPES OF WESTWOOD, NJ.

**TM000000001993.004 EPERM DATA FOR APRIL 1993

04/07/93-05/07/93 DATA ACQUIRED PER WI-RM-770, REV. 4.

ACQN/DEVL LOCATION : ALI NEAR EIELD SITES AND FAR FIELD SITE 83

**TM000000001993.005 EPERM DATA FOR MAY 1993.

05/06/93-06/01/93 DATA ACQOIRED PER WI-RM-770, REV. 4

ACQN/DEVI LOCATION : ALL NEAR FIEID SITES AND FAR FIELD SITE 83

$\star \star T M 000000001993.006$ EPERM DATA FOR JUNE 1993.

06/01/93-07/01/93 DATA ACQUIRED PER WI-RM-770, REV. 4.

ACQN/DEVL LOCATION : ALL NEAR FIELD SITES AND FAR FIELD SITE 83

**TM000000001993.007 EPERM DATA FOR JULY 1993.

07/01/93-08/04/93 DATA ACQOIRED PER WI-RM-770, REV. 4.

ACQN/DEVL LOCATION : ALL NEAR FIELD SITES AND FAR FIELD SITE 83 
RADIOLOGICAI MONITORING PLAN

* *TM000000001993.008

**TM000000001993.008 EPERM DATA FOR AUGOST 1993.

08/04/93-09/07/93 DATA ACQUIRED PER WI-RM-770, REV. 4.

ACQN/DEVL LOCATION : ALL NEAR FIELD SITES AND FAR FIELD SITE 83

**TM000000001993.009 EPERM DATA FOR SEPTEMBER 1993.

09/07/93-10/05/93 DATA ACQUIRED PER WI-RM-770, REV. 4.

ACQN/DEVL LOCATION : ALI NEAR FIELD SITES AND FAR FIELD SITE 83

**TM000000001993.042 ENVIRONMENTAL RADON MEASUREMENTS WITH PYLON CONTINUOUS RADON MONITOR FOR JONE

$06 / 04 / 93-07 / 02 / 93$ 1993.

ACQN/DEVI LOCATION : RFPD NEAR FIELD SITES 06 AND 87

**TM000000001993.043 ENVIRONMENTAL RADON MEASUREMENTS WITH PYLON CONTINDOUS RADON MONITOR FOR JOLY 1993.

$07 / 02 / 93-08 / 03 / 93$ ACQN/DEVI LOCATION : RFPD NEAR FIELD SITES 06 AND 87

**TM000000001993.044 ENVIRONMENTAL RADON MEASOREMENTS WITH PYLON CONTINUOUS RADON MONITOR FOR
AUGUST 1993.

$08 / 03 / 93-09 / 02 / 93$

ACQN/DEVL LOCATION : RFPD NEAR FIELD SITES 06 AND 87

* TM000000001993.045 ENVIRONMENTAL RADON MEASUREMENTS WITH PYLON CONTINUOUS RADON MONITOR FOR SEPTEMBER 1993.

$09 / 02 / 93-10 / 01 / 93$

ACQN/DEVI LOCATION : RFPD NEAR FIELD SITES 06 AND 87
DATA ACQOIRED IN ACCORDANCE WITH TMSS WORK A Y C INSTRUCTION WI-RM-710, REVISION 0 , ICN 0 .

DATA ACQUIRED IN ACCORDANCE WITH TMSS WORK A Y C INSTROCTION WI-RM-710, REVISION 0 , ICN 0 .

DATA ACQOIRED IN ACCORDANCE WITH TMSS WORK A Y C INSTROCTION WI-RM-710, REVISION 0 , ICN 0 . 
RADIOLOGICAL MONITORING PLAN

DATA TRACKING NO.

$\star T M 000000001993.046$ PYLON CONTINDOUS RADON MONITOR FOR OCTOBER 1993.

ACQN/DEVL LOCATION : RFPD NEAR FIELD SITES 06 AND 87

* *TM000000001993.050

$\star *$ TM000000001993.050 ENVIRONMENTAL THERMOLUMINESCENT
DOSIMETER (TLD) DATA FOR SECOND QUARTER

ACQN/DEVI PERIOD

ACQN/DEVL METHOD

$\begin{array}{llll}D & Q & & -1 \\ A & U & I\end{array}$

T A O

A I C

I A

$\begin{array}{lll}T & F & T \\ Y & I & I\end{array}$

S I

E $D$ N

10/01/93-11/02/93 DATA ACQDIRED IN ACCORDANCE WITH TMSS WORK A Y C INSTRDCTION WI-RM-710, REVISION 0 , ICN 0 . $\begin{array}{ll}\star \text { TM000000001993.050 } & \text { ENVIRONMENTAL THERMOLOMINESCENT } \\ \text { DOSIMETER (TLD) DATA FOR SECOND QUARTER }\end{array}$

$04 / 01 / 93-06 / 30 / 93$ 1993.

ACQN/DEVL LOCATION : RFPD NEAR FIELD AND FAR FIELD MONITORING SITES

**TM000000001993.051 ENVIRONMENTAL THERMOLUMINESCENT DOSIMETER (TLD) DATA FOR THIRD QOARTER 1993.

$06 / 29 / 93-10 / 04 / 93$ EXCHANGE AND HANDIING PER T\&MSS WORK INSTROCTIONS WI-RM-901, REV. 3, 902, REV. 1, 903, REV.1, AND 905, REV. 1. TLD ANALYSIS PERFORMED BY TELEDYNE ISOTOPES OF WESTWOOD, NJ.

ACQN/DEVL LOCATION : RFPD NEAR FIELD AND FAR FIELD MONITORING SITES

ENVIRONMENTAL THERMOLUMINESCENT

DOSIMETER (TLD) DATA FOR FOORTH QUARTER

1993.
$09 / 23 / 93-01 / 23 / 94$

TID EXCHANGE AND HANDIING PER TMSS WORK

INSTROCTIONS WI-RM-901, REV. 3, 902

REV.1，903，REV.1，AND 905， REV. 1. TLD ANALYSIS PERFORMED BY TELEDYNE ISOTORES OF WESTWOOD, NJ.

ACQN/DEVI LOCATION : RFPD FAR FIELD AND NEAR FIELD MONITORING SITES 
DATA TRACKING NO.

TITLE/DESCRIPTION

ACON/DEVI PERTOD

07/01/93-07/31/93 RADIOCHEMICAL ANALYSIS PERFORMED BY VENDOR.

ANAIYSIS OF 1993 VEGETATION SAMPIES.

SAMPLES FROM NEAR FIELD SITES 32, 32C,

$33,38,42,45,71,73,80,82,83$, AND

84.

ACQN/DEVI LOCATION : TELEDYNE ISOTORES OF WESTWOOD, NJ

**TM000000001994.008 CONTINOOUS AIR SAMPLER DATA FOR AUGUST 1994.

$07 / 31 / 94-08 / 31 / 94$

DATA ACOUIRED IN ACCORDANCE WITH T\&MSS WORK INSTRUCTIONS WI-RM-702, REV. 5 AND WI-RM-703, REV. 2 .

ACON/DEVI LOCATION : NEAR FIELD AND FAR FIEID CAS SITES

**TM000000001994.009 CONTINUOOS AIR SAMPLER DATA FOR SEPTEMBER 1994 .

$08 / 29 / 94-10 / 05 / 94$

DATA ACQOIRED IN ACCORDANCE WITH T\&MSS WORK INSTRUCTIONS WI-RM-702, REV. 5, AND WI-RM-703, REV. 2

ACQN/DEVL LOCATION : NEAR FIELD AND FAR FIEID CAS SITES

*TM000000001994.012 CONTINDOOS AIR SAMPLER DATA FOR DECEMBER 1994.

$11 / 28 / 94-12 / 27 / 94$

DATA ACOOIRED IN ACCORDANCE WITH T\&MSS WORK INSTROCTIONS WI-RM-702, REV. 5 AND WI-RM-703, REV. 2 .

ACQN/DEVL LOCATION : NEAR FIELD AND FAR FIELD CAS SAMPLE LOCATIONS

**TM000000001994.020 ENVIRONMENTAL RADON MEASUREMENTS FOR AUGOST 1994. THIS DATA IS SUPPLEMENTE BY DATA IDENTIEIED BY DATA TRACKING NOMBER TM000000001994.024.

07/31/94-09/06/94 DATA ACQOIRED IN ACCORDANCE WITH T\&MSS A Y C WORK INSTRUCTION WI-RM-770, REV. 4, ICN 0

ACQN/DEVL LOCATION : RFPD FAR FIELD AND NEAR FIEID SAMPLE SITES 
RADIOLOGICAL MONITORING PLAN

DATA TRACKING NO.

TITLE/DESCRIPTION

EPERM DATA FOR SEPTEMBER 1994. THIS DATA IS SOPPLEMENTED BY DATA IDENTIFIED BY DATA TRACKING NOMBER TMO00000001994.024.

ACQN/DEVL LOCATION : AIL NEAR FIELD SITES AND FAR FIEID SITE 83

*TM000000001994.024 ENVIRONMENTAL RADON MEASOREMENTS FOR DECEMBER 1994. THIS DATA SOPPIEMENTS DATA IDENTIFIED BY DATA TRACKING NUMBERS TM000000001994.013, TM000000001994.014 TM000000001994.015, TM000000001994.016, TM000000001994.017, TM000000001994.018, TM000000001994.019, TM000000001994.020, TM000000001994.021, TM000000001994.022, TM000000001994.023.

ACQN/DEVL LOCATION : RFPD NEAR FIELD AND FAR EIELD SAMPLE LOCATIONS

**TM000000001994.041 ENVIRONMENTAL RADON MEASUREMENTS WITH PYLON CONTINUOOS RADON MONITOR FOR MAY 1994. THIS DATA IS SUPPLEMENTED BY DATA IDENTIFIED BY DATA TRACKING NUMBER TM000000001994.048.

ACQN/DEVL LOCATION : RFPD NEAR FIELD SITES 06 AND 87

$\star \star T M 000000001994.042$
ENVIRONMENTAL RADON MEASUREMENTS WITH PYLON CONTINUOOS RADON MONITOR FOR JUNE 1994. THIS DATA IS SUPPLEMENTED BY DATA IDENTIFIED BY DATA TRACKING NUMBER TM000000001994.048.

ACQN/DEVL LOCATION : RFPD NEAR FIELD SITES 06 AND 87
06/02/94-06/30/94 DATA ACQUIRED IN ACCORDANCE WITH T\&MSS WORK INSTROCTION WI-RM-710, REVISION 1 ICN 0 . WORK INSTROCTION WI-RM-710, REVISION 1 ICN 0 .

05/03/94-05/27/94 DATA ACQUIRED IN ACCORDANCE WITH T\&MSS 
DATA TRACKING NO.

ACQN/DEVI LOCATION : RFPD NEAR FIELD SITES 06 AND 87

**TM000000001994.044 ENVIRONMENTAI RADON MEASUREMENTS WITH PYION CONTINOOUS RADON MONITOR FOR AOGOST 1994. THIS DATA IS SUPPIEMENTED BY DATA IDENTIFIED BY DATA TRACKING BY DATA IDENTIFIED BY DATA
NOMBER TMO00000001994.048.

ACQN/DEVL LOCATION : RFPD NEAR FIELD SITES 06 AND 87

**TM000000001994.045 ENVIRONMENTAL RADON MEASOREMENTS WITH PYION CONTINUOUS RADON MONITOR FOR SEPTEMBER 1994. THIS DATA IS SOPPLEMENTED BY DATA IDENTIFIED BY DATA TRACKING NOMBER TM000000001994.048.

$09 / 02 / 94-10 / 07 / 94$ DATA ACQOIRED IN ACCORDANCE WITH T\&MSS WORK INSTRUCTIONS WI-RM-710, REVISION 1 .
DATA ACQOIRED IN ACCORDANCE WITH TEMSS WORK INSTRDCTION WI-RM-710, REVISION 1 ICN 0 .

ACQN/DEVI LOCATION : RFPD NEAR FIELD MONITORING SITES 06 AND 87

*TM000000001994.048 ENVIRONMENTAL RADON MEASUREMENTS WITH PYION CONTINOOUS RADON MONITOR FOR DECEMBER 1994. THIS DATA SOPPIEMENTS DATA IDENTIFIED BY DATA TRACKING NOMBER TM000000001994.039, TM000000001994.040, TM000000001994.041, TM000000001994.042, TM000000001994.043, TM000000001994.044, TM000000001994.045, TM000000001994.046, TM000000001994.047.

ACQN/DEVL LOCATION : RFPD NEAR FIELD SAMPLE LOCATIONS 06 AND 87
$12 / 02 / 94-01 / 05 / 95$

DATA ACQOIRED IN ACCORDANCE WITH T\&MSS WORK INSTROCTIONS WI-RM-710, REVISION 1 . 
RADIOLOGICAL MONITORING PLAN

DATA TRACKING NO.

TITLE/DESCRIPTION

**TM000000001994.049 ENVIRONMENTAL THERMOLOMINESCENT DOSIMETER (TLD) DATA FOR FIRST QDARTER 1994 .

ACON/DEVL LOCATION : RFPD NEAR FIELD AND FAR FIELD MONITORING SITES

**TM000000001994.050 ENVIRONMENTAI THERMOLOMINESCENT DOSIMETER (TLD) DATA FOR SECOND QUARTER 1994.

ACQN/DEVL PERIOD

ACQN/DEVL METHOD

$12 / 30 / 93-04 / 03 / 94$

TLD EXCHANGE AND HANDLING PER T\&MSS WORK INSTROCTIONS WI-RM-901, REV. 3, 902, REV. 1, 903, REV. 1, AND 905, REV. 1. TLD ANALYSIS PERFORMED BY TELEDYNE ISOTORES OF WESTWOOD, NJ
ACQN/DEVL LOCATION : RFPD NEAR FIELD AND FAR FIELD MONITORING SITES

*TMO00000001994.051 ENVIRONMENTAI THERMOLUMINESCENT DOSIMETER (TLD) DATA FOR THIRD QOARTER 1994.

$06 / 23 / 94-10 / 24 / 94$ TLD EXCHANGE AND HANDLING IN ACCORDANCE WITH T\&MSS WORK INSTROCTIONS WI-RM-901, REV. 3，902， REV.1，903，REV.1，AND 905, REV 1 TID ANAIYSIS PERFORMED BY TELEDYNE ISOTOPES OF WESTWOOD, NJ .

ACQN/DEVL LOCATION : RFPD NEAR FIELD AND FAR FIELD SAMPLE LOCATIONS

*TM000000001994.052 ENVIRONMENTAL THERMOLOMINESCENT DOSIMETER (TLD) DATA FOR FOORTH QUARTER

$10 / 04 / 94-01 / 24 / 95$

TLD EXCHANGE AND HANDLING IN ACCORDANCE WITH T\&MSS WORK INSTRUCTIONS WI-RM-901, REV. 3， 902， REV.1，903，REV.1，AND 905, REV. 1. TLD ANALYSIS PERFORMED BY TELEDYNE ISOTORES OF WESTWOOD, NJ.

ACQN/DEVL LOCATION : RFPD NEAR FIELD AND FAR FIEID SAMPLE LOCATIONS 
**TM00012562T1BA. 001

SUMMARY OF SOCIOECONOMIC DATA ANALYSES CONDUCTED IN SUPPORT OF THE RADIOLOGICA MONITORING PROGRAM DORING FY 1989 (NOVEMBER 1989).

$10 / 01 / 88-09 / 30 / 89$

\section{COLLECTION OF SECONDARY DATA WHICH} DESCRIBES THE DEVELOPMENT OF CHARACTERISTICS OF SOOTHERN NYE COUNTY. THESE DATA WERE OBTAINED FROM VALLEY ELECTRIC ASSOCIATION IN PAHROMP. DATA WAS VERIFIED BY FIEID OBSERVATIONS.

ACQN/DEVI IOCATION : $84 \mathrm{KM}$ RADIOS OF N765621.5(N), E570434.6(N)

$\star \star T M 00012562 T 1 B A .003$ YUCCA MOUNTIAN SITE CHARACTERIZATION PROJECT SUMMARY OF SOCIOECONOMIC DATA PROJECT SUMMARY OF SOCIOECONOMIC DATA RADIOLOGICAI MONITORING PROGRAM DORING FY 1990 (DECEMBER 1990).

$10 / 01 / 89-09 / 30 / 90$

COLLECTION OF SECONDARY DATA WHICH DESCRIBES THE DEVEIOPMENT CHARACTERISTICS OF SOUTHERN NYE COONTY. THESE DATA WERE OBTAINED FROM LOCAI EXPERTS IN EACH COMMONITY AND VERIEIED BY FIEID OBSERVATIONS.

ACQN/DEVL LOCATION : $84 \mathrm{KM}$ RADIUS OF N765621.5(N), E570434.6(N)

**TMO0012562T1BA.004 YOCCA MOUNTAIN SITE CHARACTERIZATION PROJECT SUMMARY OF SOCIOECONOMIC DATA ANAIYSES CONDUCTED IN SOPPORT OF THE RADIOLOGICAL MONITORING PROGRAM DORING CALENDAR YEAR 1990 (APRIL 1991).

COLLECTION OF SECONDARY DATA WHICH DESCRIBES THE DEVELORMENT CHARACTERISTICS OF SOOTHERN NYE COONTY DORING CALENDAR YEAR 1990. THESE DATA WERE OBTAINED FROM LOCAI EXPERTS IN EACH COMMONITY AND VERIFIED BY FIEID OBSERVATIONS.

ACQN/DEVL LOCATION : $84 \mathrm{KM}$ RADIUS OF N765621.5(N), E570434.6(N)

**TM00012562T1BA.006 YOCCA MOONTAIN SITE CHARACTERIZATION PROJECT SOMMARY OF SOCIOECONOMIC DATA ANALYSES CONDUCTED IN SOPPORT OF THE RADIOLOGICAI MONITORING PROGRAM DORING CALENDAR YEAR 1991 (APRII 1992)
$01 / 01 / 91-12 / 31 / 91$

\section{DES} DESCRIBES THE DEVELOPMENT CHARACTERISTICS OF SOUTHERN NYE COUNTY AND PORTIONS OF CIARK COUNTY. THESE DATA WERE OBTAINED VERIFIED BY FIEID OBSERVATIONS.

ACQN/DEVL LOCATION : $84 \mathrm{KM}$ RADIUS OF $1162535.1 \mathrm{~W} \quad 3651 \quad 05.46 \mathrm{~N}$ 
RADIOLOGICAL MONITORING PLAN

DATA TRACKING NO.

TITLE/DESCRIPTION

YOCCA MOUNTAIN SITE CHARACTERIZATION ANALYSES CONDOCTED IN SOPPORT OF THE RADIOLOGICAL MONITORING PROGRAM DURING CALENDAR YEAR 1992 (MAY 1993)

ACON/DEVI PERIOD

$01 / 01 / 92-12 / 31 / 92$

\section{COTI}

DEVELOPMENTAI CHARACTERISTICS OF SOOTHERN NYE COONTY, PORTIONS OF CLARK COONTY, AND PORTIONS OF DEATH VALLEY NATIONAL MONOMENT, CAIIFORNIA. THESE DATA WERE OBTAINED FROM IOCAI EXPERTS WITHIN THE COMMONITIES, FROM FIELD OBSERVATIONS, AND FROM SECONDARY SOURCES.

ACQN/DEVL IOCATION : $84 \mathrm{KM}$ RADIUS OF N765621.5(N), E570434.6(N)

**TM00121362T1EA.001 YUCCA MODNTAIN SITE CHARACTERIZATION PROJECT SUMMARY OF SOCIOECONOMIC DATA ANALYSES CONDOCIED IN SUPPORI OF THE RADIOLOGICAL MONITORING PROGRAM DURING CALENDAR YEAR 1993 (JONE 1994)

$01 / 01 / 93-12 / 31 / 93$ COLLECTION OF DATA THAT DESCRIBES THE DEVELOPMENTAL CHARACTERISTICS OF SOOTHERN NYE COUNTY AND PORTIONS OF CLAARK COONTY, NEVADA, AS WELL AS PORTIONS OF DEATH VALLEY NATIONAL MONOMENT, CALIFORNIA. THESE DATA WERE OBTAINED FROM LOCAL EXPERTS WITHIN THE COMMONITIES, FROM FIELD OBSERVATIONS, AND FROM SECONDARY SOURCES. 
DATA TRACKING NO.

TITLE/DESCRIPTION

ACQN/DEVL PERIOD

ACON/DEVL METHOD

04/15/93-05/06/94 SAMPLE COLLECTING AND PROCESSING ACTIVITIES WERE CONDOCTED IN ACCORDANCE WITH BTP-SMF-008 REV. 3, ICN 3, YIP-SII.2Q.SMF $0 / 0,1 / 0,2 / 0$. DRIIIING SOMMARIES (QA) $\left(0.0^{\prime}-2223.6^{\prime}\right)$ IITHOLOGIC LOGS (QA) $\left(1280.0^{\prime}-2223.6^{\prime}\right)$ \& STROCTORAL LOGS (QA) $\left(1282.0^{\circ}-2223.6^{\prime}\right)$

ACQN/DEVL LOCATION : N771,309.8(N) E560,141.6(N) ELEVATION 4425.4'

*TM000000000214.002 OSW OZ-14 STROCTORAL IOGS (NOA) $\left(0.0-1282.0^{\prime}\right) \&$ IITHOLOGIC LOGS (NQA)

04/15/93-05/06/94 SAMPIE COLLECTING AND PROCESSING ACTIVITIES WERE CONDUCTED IN ACCORDANCE $\left(0.0^{\prime}-1280.0^{\prime}\right)$ WITH BTP-SMF-008 REV. 3 , ICN 3.

ACQN/DEVL LOCATION : N771,309.8(N) E560,141.6(N) ELEVATION 4425.4'

*TM000000000216.001 OE-25 UZ\#16 PREIIMINARY COMPOSITE BOREHOLE LOG, STROCTORAI IOGS, LITHOLOGIC IOGS, SHIFT DRILIING SUMMARIES FROM $0.0^{\prime}-1686.2^{\prime}$.

05/27/92-03/11/93 SAMPLE COLIECTING AND PROCESSING ACTIVITIES WERE CONDUCTED IN ACCORDANCE WITH BTP-SMF-008 REV. $2 /$ ICN $1,3 / 0,3 / 1$, $3 / 2, \& 3 / 3$.

ACQN/DEVL LOCATION : N:760,535.2(N) E:564,857.5'(N) ELEVATION 4000.6

**TM0000000SD9RS.001 TSW SD-9 SHIFT DRIIIING SUMMARIES

$\left(7.4^{\prime}-1489.2^{\prime}\right)$, STROCTORAL IOGS

$\left(5 \dot{3}^{\prime} 6^{\prime}-1488.0^{\prime}\right)$, STRUCTURAL LOGS

SAMPLE COLLECTING AND PROCESSING ACTIVITIES ARE PERFORMED BY THE DRIILING ACTIVITIES ARE PERFORMED BY THE DRILLING IN ACCORDANCE WITH YLP-SII.2Q-SME, FIEID LOGGING, HANDIING, AND DOCUMENTING BOREHOLE SAMPLES.

$\left(0.0-1450.0^{\prime}\right)$

ACQN/DEVL LOCATION : N767,974(N) $4270 ;$ (EST) E561,805(N) (EST) GROOND ELEV. 
SITE CHARACTERIZATION PLAN BASELINE

DATA TRACKING NO.

TITLE/DESCRIPTION

ACQN/DEVI PERIOD

$08 / 22 / 94-09 / 02 / 94$

OSW SD-9 SHIFT DRILLING SUMMARIES,

STROCTURAI LOGS, AND IITHOLOGIC LOGS FROM APPROX. 1450.0' TO 1690.6 .

ACQN/DEVL LOCATION : N767,974(N) (EST) E561,805(N) (EST) GROUND ELEV.

$4270^{\prime}$ (EST)

**TM0000000SD9RS.003 USW SD-9 SHIFT DRILIING SUMMARIES,

USW SD-9 SHIFT DRILLING SUMMARIES,
STROCTURAI LOGS, AND LITHOLOGIC LOGS STROCTURAL LOGS, AND LITHOLOGI
FROM APPROX. $1665^{\prime}$ TO $2030.6^{\prime}$.

09/06/94-09/21/94 SAMPIE COLLECTING AND PROCESSING ACTIVITIES ARE PERFORMED BY THE DRILLING ACTIVITIES ARE PERFORMED BY THE DRILLING
SOPPORT AND SAMPIE MANAGEMENT DEPARTMENT IN ACCORDANCE WITH PROCEDORE "FIELD IN ACCORDANGS, HANDLING, AND DOCUMENTING BOREHOLE SAMPIES".

ACQN/DEVL LOCATION : N767,974(N) (EST) E561,805(N) (EST) GROOND ELEV.
01/28/94-03/31/94 SAMPIE COLLECTING AND PROCESSING ACTIVITIES ARE PERFORMED BY DS\&SM IN

\section{ACCORDANCE WITH YLP-SII. 2Q-SMF, FIELD
LOGGING, HANDLING, AND DOCUMENTING \\ ACTIVITIES ARE PERFORMED BY DS\&SM I
ACCORDANCE WITH YLP-SII.2Q-SMF, FIE
LOGGING, HANDLING, AND DOCUMENTING
BOREHOLE SAMPLES.}

**TM000000SD12RS.006 DSW SD-12 SHIFT DRILIING SUMMARIES $\left(0.0^{\prime}-300.8^{\prime}\right)$; STRUCTURAL LOGS $\left(53.0^{\prime}-295.8^{\prime} j\right.$, AND IITHOLOGIC LOGS $\left(0.0^{\prime}-278.3^{\prime}\right)$.

ACQN/DEVL LOCATION : N761,956.59(N) (EST) ELEV.: $4342.99^{\prime}$ (EST) 
**TM000000SD12RS.008 USW SD-12 SHIFT DRILIING SUMMARIES, LITHOLOGIC LOGS, AND STROCTORAI LOGS.

$08 / 01 / 94-08 / 19 / 94$

SAMPIE COITECTING AND PROCESSING

ACTIVITIES ARE PERFORMED BY THE DRILIING SOPPORT AND SAMPIE MANAGEMENT DEPARTMENT IN ACCORDANCE WITH YLP-SII.2Q-SMF, FIELD IOGGING, HANDIING, AND DOCOMENTING BOREHOLE SAMPIES.

ACQN/DEVL LOCATION : N761956.60(N) E561605.70(N) GROUND ELEV. 4343.0'

*TMO000SD9SUPER.001 USW SD-9 CHANGES TO IITHOIOGIC IOG SUBMITTED UNDER DTN: TMO000000SD9RS.003. THIS DATA SUPERSEDES ITTHOLOGIC IOG DATA (P. 71)

\section{ACQN/DEVL LOCATION : N767,974(N) E561,805(N) ELEVATION 4270.0'}

Activity - 8.3.1.2.1.1.1

**GS920708312111.005 PRECIPITATION DEPTH, IN INCHES, COLLECTED OSING A NETWORK O NON-AOTOMATED, COLIECTOR-TYPE PLASTIC GAOGES. MEASOREMENTS WERE TAKEN AFTER EACH MAJOR PRECIPITATION EVENT AND TOTALIED FOR EACH MONTH

01/01/90-09/30/91 PRECIPITATION AMOUNTS WERE READ DIRECTLY FROM A SCALE IMPRINTED ON THE SIDE OF THE GAUGES. MEASUREMENTS WERE MADE IN INCHES OF RAINEALI. 
SITE CHARACTERIZATION PLAN BASELINE

$\begin{array}{ll}O E-25 & \text { OZN\#21 } \\ \text { OE-25 } & \text { OZN\#22 }\end{array}$

UE -25 UZN\#23

OE-25 OZN\#28

$\mathrm{OE}-25$ OZN\#29

$\mathrm{OE}-25$ OZN\#3

OE-25 OZN\#30

UE-25 OZN\#4

$0 \mathrm{E}-25$

$\mathrm{OE}-25$

$\mathrm{OE}-25$ OZNस7

$\mathrm{OE}-25$ UZN\#8

UE-25 OZN\#85

UE -25 UZN\# 9

OE-25 UZN\#92

OE -25 OZN\#97

OE-29 UZN\#91

USW G-2

USW G-3

DSW GA-1

USW $\mathrm{H}-3$

USW $\mathrm{H}-5$

dSW $0 z-13$

USW UZ-N24

OSW OZ-N25

OSW OZ-N26

OSW OZ-N40

OSW OZ $-\mathrm{N} 41$

OSW UZ-N42

USW OZ-N43

DSW

DSW

DSW

OSW OZ-N50

OSW OZ-N51

OSW OZ-N52 
OSW OZ-N65

DSW OZ-N67

USW OZ-N67

USW OZ-N68

गSW $02-169$

USW OZ-N70

OSW OZ-N71

OSW OZ-N72

OSW OZ-N73

OSW OZ $-\mathrm{N} 74$

OSW OZ-N75

סSW OZ-N76

OSW OZ-N77

OSW OZ-N78

USW OZ-N79

OSW OZ-N80

OSW OZ-N81

DSW $0 Z-N 82$

OSW UZ-N83

OSW $0 Z-N 86$

USW UZ-N86

OSW OZ-N87

OSW OZ-N88

OSW OZ-N89

OSW OZ-N9O

OSW UZ-N93

OSW UZ-N94

OSW OZ-N95

USW OZ-N96

OSW OZ-N98

WREN WASH

WX STATION 1

WX STATION 4 (NEW)

WX STATION 4 (OLD)

WX STATION 5 
SITE CHARACTERIZATION PLAN BASELINE

DATA TRACKING NO.

TITLE/DESCRIPTION

ACQN/DEVL PERIOD

Activity - 8.3.1.2.1.2.1

*GS921108312121.001 SURFACE WATER DISCHARGE DATA INCLUDING CORIES OF RECORDER CHARTS AND PRECIPITATION DATA COLLECIED DURING THE 1992 WATER YEAR FOR YOCCA MOONTAIN AND VICINITY, NYE COUNTY, NV, AND INYO COUNTY CA.

ACON/DEVI LOCATION - $3730^{\prime} 00^{\prime \prime N} 11613^{\prime} 45^{\prime \prime W}$ $3450^{\prime} 55^{\prime \prime N} 117$ 00, $00^{\prime \prime} \mathrm{W}$

**GS930908312121.003 SURFACE-WATER DISCHARGE DATA, INCLUDING COPIES OF RECORDER CHARTS, DISCHARGE MEASUREMENT NOTES AND PRECIPITATION DATA, COLLECTED DORING WATER YEARS 1986-1990 FOR YOCCA MOUNTATN AND VICINITY, NYE COUNTY, NEVADA: PART A, ENDING 5/2/89
$10 / 01 / 91-09 / 30 / 92$

THESE DATA WERE COLLECTED ONDER HP\#'S HP-43,R1\&R2, INSTALL., OPER., \& INSPECT OF TWO TYPES OF NON-RECORDING RAIN GAGES, HP-54, RO\&R1, WATER-FIOW MEAS USING 90 DEG V-NOTCH WEIRS, FLUMES, \& BARRELS, HP-91, R3, COLLECT \& FIELD ANAIY OF SURFACE-WATER SAMPLES, HP-100,R0, R1， STREAM DISCHARGE MEAS OSING A TYPE-AA PRICE CORRENT METER, HP-114, RO\&R1, EST OF STREAMFLOW DISCHARGE HP-115,R1, DETER OF PEAK STREAMFIOW DISCHARGE USING CULVERTS, HP-116, R0\&R1 DISCHARGE USING CULVERTS, HP-116, RO\&R1, REC-STREAMFLOW GAGE THAT USES A STILL-WELI REC-STREAMFLOW GAGE THAT USES A STILLSYSTEM (WITH A CONT GRAPHIC RECORDER), HP-117, R0\&R1, INSTALL, INSPECT \& MAINT O SCOUR CHAINS AT STREAMFLOW GAGING SITES, HP-166, RO\&R1, STREAM DISCHARGE MEAS OSING A PYGMY CURRENT METER, HP

SLOPE-AREA METHOD, \& HP-219,R0, METHOD TO INSTALI, OPER \& EXAM A RECORDING STREAMFLOW GAGE USING THE FLUID DATA G-II MANOMETER SYSTEM.
$10 / 01 / 85-05 / 02 / 89$ METHODS DESC. IN USGS TWRI'S: BK. 3: CH.A1, A N C $\mathrm{A} 2, \mathrm{~A} 3 \& \mathrm{~A} 8$; $\mathrm{BK} 5: \mathrm{CH} . \mathrm{A} 1 ; \mathrm{BK} 8: \mathrm{CH} . \mathrm{A} 2 \& \mathrm{~B} 2 ; \&$ OSGS-WSP 2175. ALSO HP-40,R1, DETERM. PEAK DISCHARGE BY SLOPE-CONVEYANCE; HP-43, R1, INSTAL., OPER.\& INSPECT. 2 TYPES

NON-RECORDING RAIN GAGES; HP-44,R1, INSTAL., OPER.\& INSPECT. CREST-STAGE STRMFLOW GAGES, HP-45,Ri, INSTAL., OPER \& STM BXBBLE-GAGE STACOM MANOMETER; HP-91, ROER1, COLLECT.\& FIELD ANALY. SURF. WATER SAMPIES, HP-100, RO, SIREAM DISCHARGE MEAS . USING TYPE-AA PRICE CURRENT METER; HP-114, 
SITE CHARACTERIZATION PLAN BASEIINE

\section{DATA TRACKING NO.}

RO EST. STRMFLOW DISCHARGE; HP-115, RO\&RI, DETER. PEAK STRMFIOW DISCHARGE OSING COLVERTS; HP-116,R0, INSTAI., OPER, \& EXAM REC. -STRMFLOW GAGE THAT OSES STILIING WEII SYSTEM/ CONT. GRAPHIC RECORDER; HP-117, RO, INSTAI. INSPECT.\& MAINT. SCOOR CHAINS AT STRMFLOW GAGING SITES; HP-166,R0, STRM. DISCHARGE MEAS OSING PYGMY CURRENT METER; HP-169, RO, DETER. PEAK STRM. DISCHARGE BY SLOPE-AREA.

ACON/DEVI LOCATION : $3634^{\prime} 00^{\prime \prime N} 11548^{\prime} 40 " \mathrm{~W}$ $3626^{\prime} 09^{\prime \prime N} 116 \quad 04^{\prime} 28$ " W $36 \quad 48,27 " \mathrm{~N} 116$ 05, 41 "W $3633^{\prime} 40 " \mathrm{~N} 11606^{\prime} 00^{\prime \prime} \mathrm{W}$ $36 \quad 37^{\prime} 35^{\prime \prime N} 116 \quad 08^{\prime} 31$ " $\mathrm{W}$ 36 41'08"N 116 08'52"W 37 09,51"N 116 12,11"W 35 50,55"N $116 \quad 13^{\prime} 45^{\prime \prime} \mathrm{W}$ 36 44'17"N 116 13'58"W 37 10'57"N $116 \quad 15^{\prime} 59$ "W 36 46,06"N 116 19'23"W $3611{ }^{\prime} 48 " \mathrm{~N} 116222^{\prime} 06^{\prime \prime} \mathrm{W}$ 36 53'13"N 116 22,50" 36 51,58"N 116 23.38" 36 49.13"N $116230^{3} 5{ }^{\circ}$ 36 48. $11623{ }^{\prime \prime}$ $3647,35 " N$ N $116244^{\prime} 29^{\prime \prime W}$ 3651,06 "N 11625,29 W $36510^{\prime \prime N ~} 1162544$ 3640 ' 18 "N $11626^{\prime} 03^{\prime \prime}$ 3651 '16"N $11627.07 " \mathrm{~W}$ 36 56, 37"N 116 43,09" 36 52,06"N 116 45'34"W 
SITE CHARACTERIZATION PLAN BASELINE

DATA TRACKING NO.

TITLE/DESCRIPTION

$\star \star G S 930908312121.004$ SURFACE-WATER DISCHARGE DATA, INCLUDING COPIES OF RECORDER CHARTS, DISCHARGE MEASOREMENTS NOTES, AND PRECIPITATION DATA COLLECTED DORING WATER YEARS 1986-1990 FOR YOCCA MOUNTAIN AND VICINITY, NYE COUNTY, NEVADA: PART B, BEGINNING $5 / 3 / 89$

ACON/DEVL TOCATION : $3634^{\prime} 00^{\prime \prime N} 11548^{\prime} 40 " \mathrm{~W}$ $366^{\prime} 06^{\prime \prime N}$ I16 $04^{\prime} 28^{\prime \prime} \mathrm{W}$ $3648^{\prime 27} \mathrm{~N} 11605^{\prime} 41^{\prime \prime W}$ $363^{\prime} 40^{\prime \prime N} 11606^{\circ} 00^{\prime \prime} \mathrm{W}$ $3637.35^{\prime \prime N} 11608$ ' 31 "W $3641^{\prime} 08^{\prime \prime N} 11608^{\prime} 52$ "W $3709,51 " \mathrm{~N} 116 \quad 12,11 " \mathrm{~W}$ $3550^{\prime} 55^{\prime \prime N} 11613^{\prime} 45^{\prime \prime} \mathrm{W}$ $3644^{\prime} 17^{\prime \prime N} 11613^{\prime} 58 " \mathrm{~W}$ $3710^{\prime} 57^{\prime \prime N} 116 \quad 15^{\prime} 59^{\prime \prime} \mathrm{W}$ $3646^{\prime} 06^{\prime \prime N} 11619^{\prime} 23^{\prime \prime W}$ $3611^{\prime} 48^{\prime \prime N} 11622^{\prime} 06^{\prime \prime W}$ $3653^{\prime} 13^{\prime \prime} 11622^{\prime} 50^{\prime \prime}$

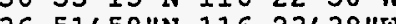
$3651,58^{\prime N} 11623^{\prime} 38^{\prime \prime N}$ 36 49.13"N $11623 \cdot 52 " \mathrm{~W}$ $3648^{\prime} 27^{\prime \prime N} 11624^{\circ} 01^{\prime \prime W}$ $3647 \cdot 35^{\prime \prime N} 11624.29 " \mathrm{~W}$ $3640^{\prime} 18^{\prime \prime N} 11626^{\prime} \mathrm{O} 3^{\prime \prime} \mathrm{W}$
ACON/DEVL PERIOD

ACON/DEVL METHOD

$\begin{array}{lll}D & Q \\ A & 0 & 1\end{array}$

$\begin{array}{lll}\text { A } & \text { O } & \text { I } \\ \text { T } & \text { A } & 0 \\ \text { A } & \text { I } & \text { C }\end{array}$

$\begin{array}{lll}T & A & O \\ A & I & C\end{array}$

I A

$05 / 03 / 89-09 / 30 / 90$

METHODS DESCRIBED IN OSGS TWRI'S: $\mathrm{CH} A 1, \mathrm{~A} 2, \mathrm{~A} 3 \& \mathrm{~A} 8$; $\mathrm{BK} 5: \mathrm{CH}$. $\mathrm{A1} ; \mathrm{BK} 8$ : CH.A2\&B2; \& OSGS-WSP 2175, ALSO HP-40,R1, DETER PEAK DISCHARGE BY SLOPE-CONVEYANCE; HP-43, R1, INSTAL., OPER. \& INSPECT. 2 TYPES OF NON-RECORD. RAIN GAGES; HP-44,R1 INSTAI. OPER.\& INSPECT. CREST-STAGE STRMFLOW GAGES, HP-45, INSTAL, OPER \& EXAM RECORDING STRMFIOW GAGE OSING BUBBLE-GAGE STACOM MANOMETER; HP- 91 RO\&R1, COLLECT \& FIELD ANALY, SURF, -WATER ROAR1, COLLECT $\&$ IELD ANALY SURE -WATER SAMPIES, HP 100, RO, STREAM DISCHARGE MEAS USING IYPE-AA PRICE CURRENT MELER; HP-114; R0, EST. STRMFLOW DISCHARGE, HP-115, R0\&R1 DETERM. PEAK STRMFLOW DISCHARGE USING COLVERIS; HP -116, R0, METHOD TO INSIALL, OPER, \& EXAM. REC.-STRMFLOW GAGE THAT OSES A STILL-WELI SYSTEM/ CONT. GRAPHIC RECORDER); HP-117,RO, INSTAL. INSPECT.\& MAINT. OF SCOUR CHAINS AT STRMFIOW GAGING SITES, HP-166,RO, STRMFIOW DISCHARGE BY SLORE-AREA METHOD. 
SITE CHARACTERIZATION PLAN BASELINE

DATA TRACKING NO.

TITLE/DESCRIPTION

ACQN/DEVL PERIOD

ACON/DEVL METHOD
$3651 \cdot 16^{\prime \prime N} 11627^{\prime} 07^{\prime \prime}$

$3656^{\prime} 37^{\prime \prime N} 11643^{\prime} 09^{\prime \prime}$

36 52, 06 "N 116 45, 34"

**GS931108312121.006 SURFACE-WATER DISCHARGE DATA INCLUDING COPIES OF RECORDER CHARTS, DISCHARGE MEASUREMENT NOTES, LEVEL NOTES, PRECIPITATION AND WATER SAMPLE ANALYSIS FOR THE YOCCA MTN. AREA, SOUTHERN NEVADA AND SODTHEASTERN CAITFORNIA, 1993 WATER YEAR.

ACON/DEVI LOCATION : $363^{\prime} 4^{\prime} 00^{\prime \prime N} 11548^{\prime} 40^{\prime \prime} \mathrm{W}$ $36.36^{\prime} 09^{\prime \prime N} 11548^{\prime} 40^{\prime \prime} \mathrm{H}$ 36 (3) $27^{\prime \prime N} 11605^{\circ} 41^{\prime \prime}$ $363^{\circ} 27^{\prime N} 11605^{\prime} 41^{\prime \prime} \mathrm{W}$ $363^{\prime} 40^{\prime \prime N} 11606^{\circ} 00^{\prime \prime} \mathrm{W}$ $36 \quad 27 \cdot 36^{\prime \prime N} 116 \quad 06^{\prime} 28^{\prime \prime} \mathrm{W}$ $3637^{\prime} 35^{\prime \prime N} 11608^{\prime} 31 " \mathrm{~W}$ $36 \quad 41^{\prime} 08^{\prime \prime N} 116 \quad 08^{\prime} 52^{\prime \prime} \mathrm{W}$ 37 09'51"N $116 \quad 12^{\prime} 11 " \mathrm{~W}$ $3550^{\prime} 55^{\prime \prime N} 116 \quad 13^{\prime} 45^{\prime \prime} \mathrm{W}$ $3644^{\prime} 17 " \mathrm{~N} 11613^{\prime} 58^{\prime \prime} \mathrm{W}$ $3710^{\prime} 57^{\prime \prime} \mathrm{N} 116 \quad 15^{\prime} 19^{\prime \prime} \mathrm{W}$ 36 46,06"N $116 \quad 19^{\prime} 23^{\prime \prime W}$ $3704^{\prime} 12$ "N $116 \quad 20^{\prime} 231 \mathrm{~W}$ $3704,19 " \mathrm{~N} 11620,50 " \mathrm{~W}$
10/01/92-09/30/93 USGS TWRI'S: BOOK 3: CH.A1, A2, A3, A4, A5, A8; A Y P BOOK 5: CH.A1; BOOK 8: CH.A2; AND OSGS-WSP 2175. ALSO HP-40,R2, EST. PEAK-STREAMFLOW DISCHARGE BY SLORE-CONVEYANCE; HP-43,R2, INSTAL. , OPER. \& INSPECT. 2 TYPES

NON-RECORDING RAIN GAGES; HP-44,R3.

INSTAI . OPER \&EXAM CREST-STAGE STRMFIOW GAGES: HP-45,R3 INSTAI OPER SEXAM. RECORDING STRMFLOW GAGE OSING BUBBLE-GAGE RTACOM MANOMETER SYSTEM, HUP $91, R 3$,

COICOM MANOMETER SYSTEM, HP- $1, R 3$, SAMPLES: HPC100,R1, SIREAM DISCHG. MEAS . USING TYPE-AA RRICE CORRENI METER; HP-114, R1, EST. STRMFLOW DISCHG.; HP-115, RI, DETER. PEAR SIRMF LOW DISCHG. USINC CULVERTS; HP-116, R1\&R2, INSTAL. OPER. \&EXAM. RECORDING STRMFIOW GAGE THAT USES STILLING-WELI SYSTEM WITH CONT. GRAPHIC RECORDER; HP-117, R2, INSTAI. INSPECT. \&MAINT. SCOUR CHAINS AT STRMFLOW GAGING SITES: HP-166, R1, STREAM DTSCHG. MEAS DSTNG PYGMY CORRENT METER; HR-169, R2, DETER. PEAK STRMFIOW DISCHG. BY SIOPE-AREA. 
SITE CHARACTERIZATION PLAN BASELINE

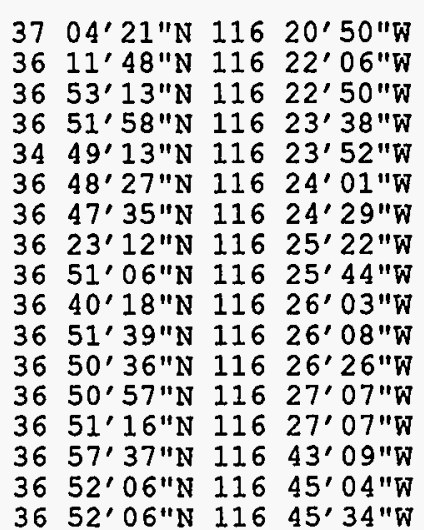

*GS941208312121.001 SURFACE-WATER DISCHARGE DATA INCLUDING COPIES OF RECORDER CHARTS, DISCHARGE MEASUREMENT NOTES, LEVEL NOTES, AND PRECIRITATION DATA FOR THE YOCCA MOONTAIN AREA, SOOTHERN NEVADA AND SOUTHERN CALIFORNIA, 1994 WATER YEAR
10/01/93-09/30/94 USGS TWRI'S: BOOK 3: CH. A3, A6, A7, A8; A Y P BOOK 5: $\mathrm{CH} \mathrm{A1;} \mathrm{BOOK} \mathrm{8:} \mathrm{CH} \mathrm{A2;} \mathrm{AND}$ USGS-WSP 2175 VOL. I AND II. ALSO HP-40, R2, EST. PEAK-STREAMFLOW DISCHARGE BY SLOPE-CONVEYANCE; HP-43, R2, INSTAI. OPER. \& INSPECT. 2 TYPES NON-RECORDING RAIN GAGES; HP-44, R3, INSTAI., ORER. \& RAIN GAGES; HP-44, R3, INSTAJ ¿̈́ OPER.

EXAM. CREST-STAGE STREAMF LOW GAGES; STREAMFIOW GAGE OSING BUBBLE-GAGE STACOM MANOMETER SYSTEM; HP-115, R2, DETERM. PEAK STREAMFLOW DISCHARGE USING CULVERTS: HP-116,R2, METHOD TO INSTALL, OPER, \& EXAM. A RECORDING STREAMFLOW GAGE THAT OSES A STILIING-WEIL SYSTEM WITH

CONTINDOUS GRAPHIC RECORDER: HP-117, R2, INSTAL. EXAM. \& MAINT. OF SCOUR CHAINS AT STREAMFLOW GAGING SITES; HP-287, RO, MTTHOD TO INSTAIL OPER; RECORDING STREAMFLOW GAGE USING OSING PRESSORE TRANSDUCER SYSTEM; HP-166, RI, STREAM DISCHARGE MEASUREMENTS USING A STREAM DISCHARGE MEA
PYGMY CURRENT METER. 
SITE CHARACTERIZATION PLAN BASELINE

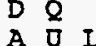

T A

A I C

$I \frac{A}{T}$

$\begin{array}{lll}T & F & T \\ Y & I & I\end{array}$

\begin{tabular}{rll}
$P$ & $I$ & $I$ \\
\hline & $E$ & 0
\end{tabular}

P E

ACQN/DEVL LOCATION : $363^{\prime} 04^{\prime \prime N} 11548^{\prime} 40^{\prime \prime} \mathrm{W}$ $3626^{\prime} 09^{\prime \prime} \mathrm{N} 1160^{\prime} 04^{\prime} 28^{\prime \prime} \mathrm{W}$ $364^{\prime} 28^{\prime} 2 \mathrm{~N} 116$ 05' 41 "W $36 \quad 33^{\prime} 40^{\prime \prime} \mathrm{N} 11606^{\prime} 00^{\prime \prime} \mathrm{N}$ $36 \quad 27 \cdot 36^{\prime \prime N} 116 \quad 06^{\prime} 28^{\prime \prime} \mathrm{W}$ 3637.35 "N 116 08'31" 3641,08 "N 116 08,52"W $3700,51 " \mathrm{~N} 11612,11 \mathrm{~N}$ 3550,55 "N 116 13. 11 " 36 $44,17 " \mathrm{~N} 116$ 13, $130^{\circ}$ 3710.57 N 116 15, $190 \mathrm{~W}$ 36 10,06 $1161519 \mathrm{~N}$ $3646^{\prime} 06^{\prime \prime N} 11619^{\prime} 23^{\prime \prime} \mathrm{W}$ 3704.12 N $11620^{\circ} 23^{\prime \prime} \mathrm{W}$

$3704^{\prime} 19^{\prime \prime N} 116 \quad 20^{\prime} 50 " \mathrm{~W}$

$3704^{\prime} 21 " \mathrm{~N} 116 \quad 20^{\prime} 50$ "W $3611^{\prime} 48^{\prime \prime N} 11622^{\prime} 06^{\prime \prime} \mathrm{W}$ $365^{\prime} 13^{\prime \prime N} 116 \quad 22^{\prime} 50 " \mathrm{~W}$ $3651^{\prime} 58^{\prime \prime N} 116 \quad 23^{\prime} 38^{\prime \prime} \mathrm{W}$ $344^{\prime} 49^{\prime} 13^{\prime \prime} \mathrm{N} 116 \quad 23^{\prime} 52^{\prime \prime} \mathrm{W}$ $\begin{array}{llll}36 & 48^{\prime} 27 " \mathrm{~N} & 116 & 24^{\prime} 01 " \mathrm{~W}\end{array}$ $3647^{\prime} 35^{\prime \prime N} 116 \quad 24^{\prime} 29^{\prime \prime} \mathrm{W}$ $3623^{\prime} 12^{\prime \prime N} 11625^{\prime} 22^{\prime \prime}$ 3651 , $06^{\prime \prime N} 11625,44 " \mathrm{~W}$ 36 40,18"N $11626^{\prime} 031 \mathrm{~W}$ $3651,391 \mathrm{~N} 11626108 \mathrm{H}$ $650,36 " N$ N 116 26, 36 52, $28^{\prime \prime N} 11626.26 \mathrm{~W}$ $3652,28 \mathrm{~N} 1162704$ "W $3650.57 \mathrm{~N} 11627.07 \mathrm{WH}$ 3651 16"N 116 27'07"W 36 51'34"N 116 27'15" 36 51'57"N $116 \quad 27 \cdot 25$ " 36 57'37"N $116 \quad 43^{\prime} 09^{\prime \prime} \mathrm{W}$ $\begin{array}{llll}36 & 52^{\prime}, 06 " N & 116 & 45^{\prime}, 04^{\prime \prime W} \\ 36 & 52,06 " N & 116 & 45^{\prime} 34^{\prime \prime W}\end{array}$ 
SITE CHARACTERIZATION RLAN BASELINE

DATA TRACKING NO

TITLE/DESCRIPTION

ACQN/DEVI PERTOD

Activity - 8.3.1.2.1.2.2

**GS910908312122.002 PARTICLE-SIZE DISTRIBOTION ANALYSES, OPHIR CREEK NEAR CARSON CITY, NV ( 39 $\left.17^{\prime} 25^{\prime \prime N} 11949^{\prime} 25^{\prime \prime W}\right)$, NOV. 16, 1990

$06 / 12 / 91-06 / 12 / 91$

ACQN/DEVL LOCATION : USGS SEDIMENT LAB, VANCOUVER, WA

**GS910908312122.003 PARTICLE-SIZE DISTRIBOTION ANALYSES, ORHIR CREEK NEAR CARSON CITY, NV 139 $\left.17^{\prime} 25^{\prime \prime N} 11949^{\prime} 25^{\prime \prime}\right)$, MAY 22, 1991.

$06 / 12 / 91-06 / 12 / 91$

ACQN/DEVL LOCATION : OSGS SEDIMENT LAAB, VANCOUVER, WA

**GS910908312122.004 PARTICLE-SIZE DISTRIBUTION ANALYSES,

OLANCHA FAN CREEK, NEAR INDEPENDENCE, CA

$06 / 12 / 91-06 / 12 / 91$ OLANCHA FAN CREEK, NEAR INDEPENDENCE, CA
$\left(3614^{\prime} 36^{\prime \prime} \mathrm{N} 11803^{\prime} 25^{\prime \prime} \mathrm{W}\right)$, NOV. $8,1990$. 14'36"N 118 03'25"W), NOV. $8,1990$.

ACQN/DEVL LOCATION : USGS SEDIMENT LAB, VANCOUVER, WA

**GS910908312122.005 RARTICLE-SIZE DISTRIBUTION ANALYSES, OLANCHA FAN CREEK NEAR INDEPENDENCE, CA

$06 / 13 / 91-06 / 13 / 91$ (36 14'36"N $\left.11803^{\prime} 25^{\prime \prime} \mathrm{W}\right)$, NOV. 9, 1990

ACQN/DEVL LOCATION : USGS SEDIMENT LAB, VANCOUVER, WA DONE BY THE OSGS SEDIMENT LAB. CASCADE VOLCANO OBSERVATORY, IN VANCOUVER, WA. ANALYSES INCLUDE STANDARD SIEVE ANALYSIS, PIPET ANAIYSIS, AND SILT-CLAY ANALYSIS.

PARTICLE-SIZE DISTRIBOTION ANAIYSES WERE DONE BY THE OSGS SEDIMENT LAB. CASCADE VOLCANO OBSERVATORY, IN VANCOUVER, WA. ANALYSES INCLUDE STANDARD SIEVE ANALYSIS
PIPET ANAIYSIS, AND SILT-CIAY ANAIYSIS.

PARTICLE-SIZE DISTRIBUTION ANALYSES WERE DONE BY THE OSGS SEDIMENT IAAB. CASCADE VOICANO OBSERVATORY, IN VANCOUVER, WA. ANALYSES INCLODE STANDARD SIEVE ANALYSIS, PIRET ANALYSIS, AND SILT-CLAY ANALYSIS.

PARTICLE-SIZE DISTRIBUTION ANALYSES WERE DONE BY THE USGS SEDIMENT LAB. CASCADE VOLCANO OBSERVATORY, IN VANCOUVER, WA. ANALYSES INCLODE STANDARD SIEVE ANALYSIS, PIPET ANALYSIS, AND SILT-CIAY ANALYSIS. 
DATA TRACKING NO.

Activity - 8.3.1.2.1.3.2

**GS920908312132.005 VERTICAI HYDRADLIC GRADIENT DATA AND INTERPRETATION FROM WELLS GS-15, -16 AND -17 . POBLISHED IN "A HINT OF

RECHARGE AT FRANKLIN LAKE PLAYA, INYO COONTY, CALIFORNIA, USA" AND "DOES IOCALIZED RECHARGE OCCDR AT A DISCHARGE AREA WITHIN THE GROUND-WATER FLOW SYSTEM OF YUCCA MOUNTAIN, NEVADA?" BY JOHN B. CZARNECKI, DANIEI RONEN, MORDECKAI MARGARITZ, AND LEVY KROITORO.

ACQN/DEVI LOCATION : USGS, DENVER, CO

**GS941108312132.003 HEAT-PUISE FLOWMETER SURVEY DATA FROM WELI OSW G-2.

ACQN/DEVL LOCATION : USW G-2

*GS950483115221.001 TEMPERATURE LOG DATA OBTAINED IN WELI USW G-2, FEBROARY, 1995 .

ACQN/DEVL LOCATION : OSW G-2
06/13/92-06/30/92 VERTICAL HYDRAOLIC GRADIENT CALCOLATED BY D N C OBTAINING THE SIOPE OF THE IINE OF BEST FIT THROOGH THE WATER-IEVEL ALTITODES OF THE THREE WELLS, GS-15, -16 , AND -17 . INTERPRETATION BASED ON EXAMINATION AND COMPARISON OF SOURCE DATA.
$11 / 21 / 94-11 / 22 / 94$ G-2."
GRP-20, R3-M1 
SITE CHARACTERIZATION PLAN BASELINE

DATA TRACKING NO.

Activity - 8.3.1.2.1.3.3

**GS941108312133.005 DEPTH-TO-WATER MEASOREMENTS IN FORTYMILE WASH WELIS, $10 / 1 / 84-5 / 2 / 89$.

ACQN/DEVL LOCATION : OE-29 A\#1

OE-29 OZN\#91

**GS941108312133.006 DEPTH-TO-WATER MEASUREMENTS IN FORTYMILE WASH WELLS, 1994 WATER YEAR.

ACQN/DEVL LOCATION : OE-25 J\#12

$$
\begin{array}{ll}
\mathrm{OE}-29 & \text { A\#1 } \\
\mathrm{OE}-29 & \mathrm{~A} \# 2
\end{array}
$$

OE-29 OZN\# 91

OSW VH-1

**GS941108312133.007 DEPTH-TO-WATER MEASOREMENTS TAKEN IN

FORTYMILE WASH WELLS, $5 / 3 / 89-9 / 30 / 91$
ACQN/DEVL LOCATION : UE-29 A\#1 OE-29 A\#2

UE -29 OZN\#9]
ACON/DEVL PERIOD

ACQN/DEVL METHOD

$10 / 01 / 84-05 / 02 / 89$

THE MEASOREMENTS WERE TAKEN WITH HAND-HELD A $\mathrm{N} C$ STEEL TAPES OR 2600 FT MOTOR DRIVEN STEEL TAPE.

$10 / 01 / 93-09 / 30 / 94$ HP-61, R0, "USE OF HAND-HELD STEEL TAPES (IN VERTICAL BOREHOLES)", AND HP-99, R1, "INSTRUCTION FOR ORERATION OF A WELI

$05 / 03 / 89-09 / 30 / 91$ HP-61, R0, "USE OF HAND-HEID STEEL TAPES (IN VERTICAI BOREHOLES)," AND HP-75, R0 AND R1, "METHODS FOR MEASURING WELLS USING REELED (2600 FT AND 2800 FT) STEEL TAPES." 
SITE CHARACTERIZATION PLAN BASELINE

DATA TRACKING NO.

01/01/84-01/25/85 AGE OF GROOND WATER SAMPLES WERE DETERMINED BY 14C LEVELS, METHOD DESCRIBED IN REPORT, CONDENSATION TEMPERATORES WERE DETERMINED ON THE BASIS OF ISOTOPE RATIOS (VAN DER STRAATEN, C.M., AND MOOK, W.G., 1983, STABLE ISOTOPIC COMPOSITION AND PRECIPITATION AND CIIMATIC VARIABILITY) COMPIETE BIBIIOGRAPHIC CITATIONS ARE IN RERORT.

ACQN/DEVL IOCATION : USGS, DENVER, CO

*GS950508312134.001 GEOHYDROLOGY AND EVAPOTRANSPIRATION AT FRANKLIN LAKE PLAYA, INYO COUNTY, CALIFORNIA, BY JOHN B. CZARNECKI. THESE DATA SUPERSEDE DATA PREVIOOSLY IDENTIFIED BY GS910408312141.001.

ACON/DEVL IOCATION : USGS, DENVER, CO
01/01/86-04/20/90 COMPIIATION OF DIRECT FIETD MEASTREMENTS AND DATA COMPOTER POTENTIOMETRIC DATA TRANSMISSIVITY AND HYDRAOIIC CONDUCTIVITY DATA,

EVAPOTRANSPIRATIONAL DATA, MOISTORE CONTENT IN ONSATURATED ZONE AND MODEL SENSITIVITY DATA.

\section{N C}


DATA TRACKING NO

TITLE/DESCRIPTION

ACQN/DEVL PERIOD

ACON/DEVL METHOD
Activity - 8.3.1.2.1.4.4

*GS950608312144.003 EFFECTS OF FAULTING ON GROUND-WATER MOVEMENT IN THE DEATH NEVADA AND CALIFORNIA, BY C.C. FAUNT

ACON/DEVL LOCATION : OSGS, DENVER, CO

Activity - 8.3.1.2.2.1.1

* GS941008312211.008 PHYSICAL PROPERTIES OF ONCONSOLIDATED SURFICIAL MATERIALS IN THE VICINITY OF YUCCA MOUNTAIN PROJECT, MARCH - SEPT. 1994

ACQN/DEVL LOCATION : N232200(N) E174100(N) $\begin{array}{ll}N 761026(\mathrm{~N}) & E 558406(\mathrm{~N}) \\ N 757000(\mathrm{~N}) & E 558500(\mathrm{~N}) \\ N 771570(\mathrm{~N}) & E 558872(\mathrm{~N}) \\ N 765728(\mathrm{~N}) & E 559436(\mathrm{~N}) \\ N 772262(\mathrm{~N}) & E 559748(\mathrm{~N}) \\ N 771968(\mathrm{~N}) & E 559784(\mathrm{~N}) \\ N 778091(\mathrm{~N}) & E 559852(\mathrm{~N}) \\ N 778224(\mathrm{~N}) & E 559995(\mathrm{~N}) \\ N 770159(\mathrm{~N}) & E 561251(\mathrm{~N}) \\ N 762264(\mathrm{~N}) & E 562310(\mathrm{~N}) \\ N 766220(\mathrm{~N}) & E 562780(\mathrm{~N}) \\ N 773900(\mathrm{~N}) & E 563583(\mathrm{~N}) \\ N 753634(\mathrm{~N}) & E 563799(\mathrm{~N}) \\ N 753962(\mathrm{~N}) & E 564006(\mathrm{~N})\end{array}$
06/01/92-09/09/94 FAOLTS AND STRAIGHT STRETCHES OF DRAINAGES D N P LONGER THAN 10KM WERE DIGITIZED AND ANAIYZED, AND THE FAOLTS WERE CLASSIFIED AS REIATIVELY TENSIONAL OR COMPRESSIONAL. INFORMATION ON SPRING LOCATIONS AND WATER IEVELS AISO ANALYZED TO SEE HOW DISCHARGE AREAS RELATE TO STROCTURAI FEATORES.

03/01/94-09/30/94 HP-263,R0, PARTICLE-SIZE ANALYSIS; HP-243, A Y C RO, METHOD FOR MEASURING THE PARTICLE VOLUME AND/OR RARTICLE DENSITY OF ROCK OR SOIL SAMPIES USING MICROMERITICS ACCOPYC 1330 PYCNOMETER; HP-259, RO, DETERMINATION OF BULK DENSITY OSING AN IRREGOLAR HOLE BULK DENSITY SAMPLER (FIELD BOLK DENSITY MEASORED AT COLLECTION SITE); HP-229,R3, DETERMINATION OF WATER CONTENT AND PHYSICAI PRORERTIES FOR ILABORATORY ROCK SAMPLES; HP-258, RO, METHOD FOR DETERMINING THE PH OF A SAMPIE; HP-265, RO, CALCIUM CARBONATE EQOIVALENT ANAIYSIS. 


\section{N760272(N) E564262(N) \\ N754461 (N) E564402(N) \\ N767890 (N) E564770 (N) \\ N768706(N) $E 566137(N)$ \\ N768724(N) E566141(N) \\ N767967 (N) E568233(N) \\ OSGS HRF, NTS, NV}

**GS950308312211.001 PRELIMINARY FAOLT/FRACTORE PROPERTIES FOR FAST-PATHWAYS MODEL
$12 / 09 / 94-03 / 06 / 95$
DATA WERE COLIECTED PER: GP-01,R2, GEOLOGIC MAPPING; GP-12, R2, MAPPING GEOLOIC MAPPING; GP-12, R2, MAPPING AIONG TRAVERSES; GP -17, R1, DESCRIBING AND ( TRENCH WALL AND NATORAL OOTCROP SAMPLINE FOR COORDINATED STUDIES; HP-229, R3, DETERMINATION OF WATER CONTENT AND PHYSICAI PRORERTIES FOR LABORATORY ROCK SAMPIES; HP-243, RO, METHOD FOR MEASOR DENSITY OF ROCK OR SOII SAMPLES USING THE MICROMETRICS ACCUPYC 1330 PYCNOMETER; HP-258, R0, METHOD TO DETERMINE THE PH OF A SAMPLE; AND HP-265,RO, CALCIOM CARBONATE EQUIVALENT ANAIYSIS.

\begin{tabular}{|c|c|c|c|}
\hline ACQN/DEVI LOCATION : & 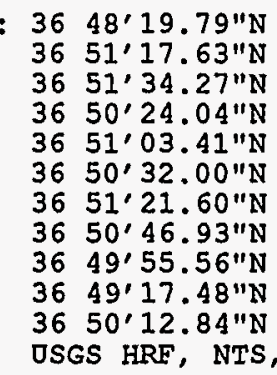 & $\begin{array}{l}116 \\
116 \\
116 \\
116 \\
116 \\
116 \\
116 \\
116 \\
116 \\
116 \\
116\end{array}$ & 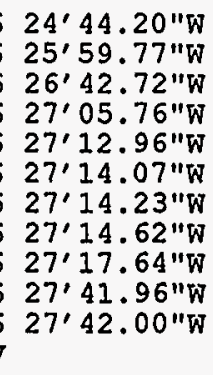 \\
\hline
\end{tabular}


Activity - 8.3.1.2.2.1.2

**GS910808312212.001 GEOHYDROLOGIC DATA COLLECTED FROM SHAILOW NEOTRON-ACCESS BOREHOLES AND RESOLTANT PREIIMINARY GEOHYDROLOGIC EVAIOATIONS, YUCCA MOUNTAIN AREA, NYE COONTY, NEVADA, BY DANIEL O BLOOT, DALE P HAMERMEISTER CAROIT I LOSKOT AND MICHAEL $P$ CHORNACK.

ACON/DEVL LOCATION : OSGS, DENVER, CO OSGS, HRF, NTS, NV

**GS940708312212.010 VOLUMETRIC WATER CONTENT FROM NEUTRON MOISTURE METER COONTS FOR 74 BOREHOLES FROM THE TIME THEY WERE DRILLED ONTIL $5 / 2 / 89$

$02 / 01 / 86-11 / 04 / 91$

THIS REPORT PRESENTS A COMPILATION OF GEOLOGIC AND HYDROLOGIC DATA FROM 74 COMPLETED NEUTRON-ACCESS BOREHOLES.

$10 / 15 / 93-06 / 30 / 94$

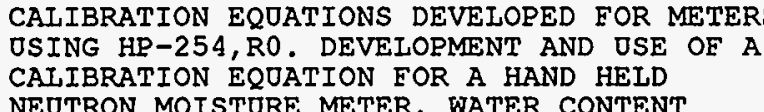
CAIIBRATION EQDATION FOR A HAND HELD NEOTRON MOISTURE METER, WATER CONTENT

ACQN/DEVL LOCATION : OSGS HYDROLOGIC RESEARCH FACILITY, NTS, NV MOISTORE METER COONTS FOR 99 BOREHOLES MOISTORE METER COUNTS FOR 99 BOREHOLES FROM 5/3/89 OR FROM THE TIME THEY WERE DRILLED ONTIL $12731 / 93$. THESE DATA SUPERSEDE DATA PREVIOOSIY DTN : GS930108312212.004 GS940108312212.006.

ACQN/DEVL LOCATION : HYDROLOGIC RESEARCH FACILITY, NTS, NV
10/15/93-06/30/94 CAIIBRATION EOUATIONS DEVELOPED EOR METERS D Y T OSING HP-254,RO, DEVELOPMENT AND DSE OF A CAING HP-254, RO, DEVELOPMENT AND HEN EOUATION FOR A HAND HELD NEUTRON MOISTORE METER, WATER CONTENT PREDICTED OSING NEOTRON MOISTORE METER COONTS 
SITE CHARACTERIZATION PLAN BASELINE

DATA TRACKING NO.

TITLE/DESCRIPTION

**GS941008312212.013 NEOTRON COONTS FOR 97 BOREHOLES AT YOCCA MOUNTAIN FROM JANOARY 1, 1994, TO OCTOBER 1, 1994

ACQN/DEVL LOCATION : UE-25 OZN\#I $O E-25$ OZN\#10 OE-25 OZN\#12 $0 \mathrm{E}-25$ O2NH13

$\mathrm{OE}-25$ UZN\#14

$0 E-25$ OLN\#18

OE-25 OZN\#19

OE-25 OZN\#2

OE-25 UZN\#20

OE-25 UZN\#21

OE-25 UZN\#22

DE-25 UZN\#23

UE-25 OZN\#28

UE-25 UZN*29

OE-25 OZNH3

$\mathrm{OE}-25$ DZN*30

(

OE-25 OZN\#39

OE-25 U2NH4

DE-25 2 ZNH 56

OE-25 OZN\#56

UE -25 OZN\# 6

UE -25 OZN\# 60

OE -25 OZN\#63

OE -25 OZN 7

OE-25 OZN\#8

OE-25 OZN\#9

OE-25 OZN\#97

DE -29 JZN\#91

DE-29 OZNH 92

OSW OZ-7

OSW OZ-N11

0SW 0Z-N15

OSW OZ-N16

OSW OZ-N17

OSW OZ-N24

OSW OZ-N25

OSW OZ-N26
ACQN/DEVL PERIOD

ACQN/DEVL METHOD

$D 2$

$T$ A

A $C$

A I C

T $F T$

$Y$ I I

E D N

01/01/94-10/01/94 MOISTURE METER COONTS WERE COILECTED AT BOREHOLES IN ACCORDANCE WITH HP-62, R6 AND

A Y T R6-M1, METHOD FOR MEASURING SUB-SORFACE MOISTURE CONTENT OSING NEOTRON MOISTORE METER 


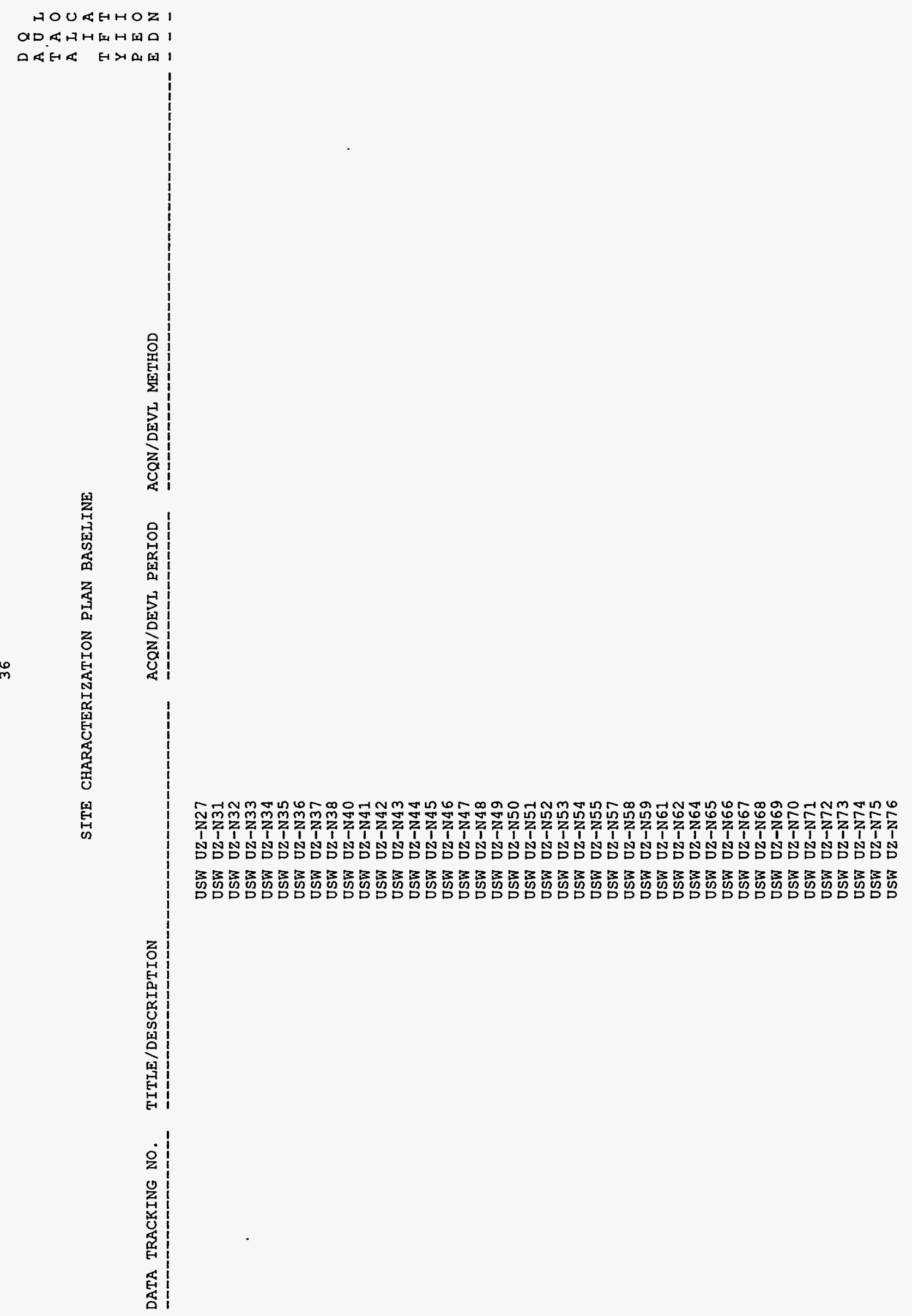


SITE CHARACTERIZATION PIAN BASELINE

DATA TRACKING NO.

TITLE/DESCRIPTION

ACQN/DEVL PERIOD

ACON/DEVL METHOD

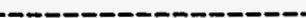

**GS941108312212.016 PHYSICAI PROPERTIES OF CORE SAMPLES FROM BOREHOLES OE-25 OZN"10, OSW OZ-N24, OSW OZ-N46, OSW OZ-N47, AND OSW OZ-N98.

$02 / 01 / 86-05 / 22 / 86$ DATA ACQUIRED ACCORDING TO THE FOLLOWING PROCEDORES: BOLK SPECIFIC GRAVITY AND MOISTORE CONTENT, ASTM D1188-71; GRAIN DENSITY, ASTM D854; BULK DENSITY, ASTM D1 1188, AND ASTM D 1188. POROSITY

CALCOLATED USING BOLK AND GRAIN DENSITY VALUES.

ACQN/DEVI LOCATION : HOLMES \& NARVER MATERIAIS TESTING IAB; MERCURY, NV

**GS941208312212.017 SUBSURFACE WATER CONTENT AT YUCCA MOUNTAIN NEVADA - NEOTRON LOGGING DATA MODNTAIN NEVADA -- NEOT
FOR $1 / 1 / 94$ THRO FY94

ACQN/DEVL LOCATION : USGS HRE, NTS, NV
$01 / 01 / 94-09 / 30 / 94$

VOLUMETRIC WATER CONTENTS WERE DETERMINED BY APRIYING CAIIBRATION EQUATIONS AND

IAB-TO-F IELD TRANSFER EQUATIONS DEVELORED IN ACCORDANCE WITH HP-254, R0, DEVELOPMENT AND USE OF A CALIBRATION EQUATION FOR A HAND HELD NEUTRON MOISTURE METER, TO THE NEOTRON COONTS OBTAINED AT THE BOREHOIES. 
SITE CHARACTERIZATION PLAN BASELINE

DATA TRACKING NO.

TITLE/DESCRIPTION

* GS950308312211.001 PRELIMINARY FAULT/FRACTURE PROPERTIES

$*$ GS 950308312211.001
FOR FAST-PATHWAYS MODEL
ACON/DEVI PERIOD

$12 / 09 / 94-03 / 06 / 95$

ACQN/DEVL METHOD

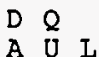

$\begin{array}{lll}A & U & I \\ T & A & O\end{array}$

$\begin{array}{lll}T & A & O \\ A & L & C\end{array}$

A L C

DATA WERE COLLECTED PER: GP-01,R2,

GEOLOGIC MAPPING; GP-12,R2, MAPPING FRACTORES ON PAVEMENTS, OUTCROPS, AND ALONG TRAVERSES; GP -17, R1, DESCRIBING AND SAMPLING SOILS IN THE FIELD; GP-27, R2, TRENCH WALL AND NATURAL OUTCROP SAMPIING FOR COORDINATED STODIES; HP-229, R3,

DETERMINATION OF WATER CONTENT AND

PHYSICAL PROPERTIES FOR LABORATORY ROCK SAMPIES; HP-243, RO, METHOD FOR MEASURING THE PARTICLE VOLOME AND/OR PARTICIE DENSITY OF ROCK OR SOII SAMPLES OSING THE MICROMETRICS ACCUPYC 1330 PYCNOMETER;

HP-258,RO, METHOD TO DETERMINE THE PH OF HP-258, RO, METHOD TO DETERMINE THE PH OF
SAMPLE; AND HP-265, RO, CAICIUM CARBONATE EQUIVALENT ANALYSIS.

ACQN/DEVL LOCATION : $3648^{\prime} 19.79^{\prime \prime N} 11624^{\prime} 44.20^{\prime \prime} \mathrm{W}$ $3651^{\prime} 17.63^{\prime \prime N} 116 \quad 25^{\prime} 59.77 " \mathrm{~W}$ 3651 34.27"N $11626^{\prime} 42.72$ "W $3650,24.04 " \mathrm{~N} 11627^{\prime} 05.76 " \mathrm{~W}$ $3651,03.41 " \mathrm{~N} 11627{ }^{\prime} 12.96 " \mathrm{~W}$ $3650,32.00 " \mathrm{~N} 11627,14.07 " \mathrm{~W}$ 36 51,21.60"N $1162719.23{ }^{\prime \prime}$ 36 50.46.93"N $1162714.231 \mathrm{~W}$ $3650.46 .93 \mathrm{~N} 11627 \cdot 14.62 \mathrm{~W}$ $3649.55 .56 " \mathrm{~N} 1162717.64 \mathrm{~N}$ $364917.48 " \mathrm{~N} 11627.41 .96 " \mathrm{~W}$ 3650 12.84"N $116 \quad 27^{\prime} 42.00 " \mathrm{~W}$ USGS HRF, NTS, NV 
SITE CHARACTERIZATION PLAN BASELINE

DATA TRACKING NO.

TITLE/DESCRIPTION

Activity - 8.3.1.2.2.1.3

**GS941008312213.013 CALCULATED VOLOMES OF WATER THAT ENTERED THE CONEINING RING SURROUNDING BOREHOLE OE-25 OZN\#7 IN PONDING EXPERIMENT

ACQN/DEVL LOCATION : OSGS HRF, NTS, NV

**GS941108312213.014 NEUTRON COONTS FOR 5 BOREHOLES USED IN THE OE-25 OZN\#7 PONDING EXPERIMENT

ACQN/DEVI IOCATION : OE-25 OZN\#4

$$
\begin{array}{ll}
O E-25 & \text { OZN\#5 } \\
O E-25 & \text { OZN\#6 } \\
O E-25 & \text { UZN\#7 }
\end{array}
$$

OE-25 UZN\#8

* GS941208312213.015 SUBSURFACE WATER CONTENT AT 5 BOREHOLES OSED IN THE UE-25 UZN\#7 PONDING EXPERIMENT

ACQN/DEVL IOCATION : USGS HRF, NTS, NV

\section{ACON/DEVI PERIOD}

ACQN/DEVL METHOD

09/30/94-10/05/94 HP-273,R0, METHOD FOR MEASURING SURFACE INFIITRATION RATES USING A CONSTANT-HEAD RING INEILTROMETER. VOLUME OF WATER ENTERING THE CONF INING RING SURROONDING BOREHOLE OE-25 OZN\#7 WAS CALCOLATED OSING THE RECORDED COMOLATIVE POLSES AND THE TORBINE PULSE FLOW METER CONVERSION OF 75.7 POLSES/GAI.

09/19/94-09/30/94 NEOTRON COONTS OBTATNED AT THE BOREHOLES IN ACCORDANCE WITH HP-62, R6 \& R6-M1, METHOD FOR MEASORTNG SUB-SURFACE MOISTOR CONTENT OSING A NEOTRON MOISTORE METER

09/19/94-09/30/94 VOLOMETRIC WATER CONTENTS WERE DETERMINED

BY APPIYING CAITIBRATION EODATIONS AND

LAB-TO-F IELD TRANSFER EOUATIONS DEVELOPED

IN ACCORDANCE WITH HP-254,RO, DEVELOPMENT

AND OSE OF A CAIIBRATION EOUATION FOR A

HAND HEID NEOTRON MOISTORE METER, TO THE

NEOTRON COUNTS OBTAINED AT THE BOREHOLES. 
DATA TRACKING NO.

TITLE/DESCRIPTION

ACON/DEVI PERTOD

$01 / 27 / 95-02 / 07 / 95$

$\star_{G S 950308312213.003}$ SELECTED SURF ICIAL MATERIAI SAMPLES.

ACQN/DEVL LOCATION : USGS HRF, AREA 25, NTS, NV

*GS950308312213.004 CUMUTATIVE INEIITRATION AND SURFACE FLDX RATES CONDUCTED IN FORTYMILE WASH AND RATES CONDUCTED IN FORTYMILE WASH AND NEAR OE-25 UZN\#7, CAI
MILLIVOLT READINGS.

$01 / 18 / 95-03 / 01 / 95$

ACQN/DEVL LOCATION : USGS HRF, NTS, NV

Activity - 8.3.1.2.2.3.1

**GS930708312272.006 PERMEABILITY AND FLUID CHEMISTRY STUDIES OF THE TOPOPAH SPRING MEMBER OF THE PAINTBROSH TUFE, NEVADA TEST SITE: PART II, BY D.E. MOORE, C.A. MORROW, AND J.D. BYERLEE.

$01 / 01 / 83-01 / 01 / 84$

THREE EXPERIMENTS WERE PERFORMED TO TEST THE EFFECT OF PORE PRESSURE, SAMPLE ORIENTATION, AND FLOW DIRECTION ON PERMEABILITY AND RORE-FLUID CHEMISTRY. VARIATIONS IN PERMEABILITY WITH TIME DETERMINED FROM MEASURED CHANGES IN MASS DIOW RATE WHTIE PORE PRESSORE GRADIENT DOW RATE WRITE HELD CONSTAN DESCRIBED IN MORROW, EI.AL. (1984) AND MOORE, EI.AL. (1984) . SAMPLE FLUIDS COLLECTED DURING TESTING WERE ANALYZED OSING TECHNIQUES DESCRIBED IN MOORE (OR.CIT.) AND "SOLMNEQ" PROGRAM (KHARAKA AND BARNES, 1973). COMPLETE BIBLIOGRAPHIC CITATIONS IN REPORT. 
SITE CHARACTERIZATION PIAN BASEIINE

(1)

**GS950308312231.003 UE-25 OZ\#16 PYCNOMETER DATA, JANOARY 18 1994 - JULY 19, 1994

$01 / 18 / 94-07 / 19 / 94$

DATS "DETERMINATION OF WATER CONTENT AN PHYSICAL PROPERTIES FOR LABORATORY ROCK SAMPLES", AND HP-243, RO, "METHOD FOR MEASURING THE PARTICLE VOLUME AND/OR PARTICAI DENSITY OF ROCK OR SOIL SAMPIES OSING THE MICROMETRICS ACCDPYC 1330 PYCNOMETER". AII SAMPLES WERE OVEN-DRIED AT 05 I AT 1O5 DEGRES C ACCORDING TO HP $229, \mathrm{R} 3$

ACQN/DEVI LOCATION : USGS HRF, AREA 25, NTS, NV

*GS950408312231.004 PHYSICAL PROPERTIES AND WATER POTENTIALS OF CORE FROM BOREHOLE OSW SD-9

$07 / 01 / 94-12 / 30 / 94$ DATA WERE COILECTED PER HP-229, R2 AND R3
"DETERMINATION OF WATER CONTENT AND
PHYSICAL PROPERTIES FOR IAAORATORY ROCK
SAMPLES." AND HP-255, R0, "DETERMINATION WATER ACTIVITY SYSTEM."

ACQN/DEVL LOCATION : USGS HYDROIOGIC RESEARCH FACILITY, NTS, NV

*GS950408312231.005

PHYSICAI PROPERTIES AND WATER POTENTIAIS OF CORE FROM BOREHOLE OSW OZ-14.

$03 / 01 / 94-06 / 30 / 94$ DATA WERE COLLECTED PER HP-229, R2 AND R3,
"DETERMINATION OF WATER CONTENT AND
PHYSICAI PROPERTIES FOR LABORATORY ROCK
SAMPLES." AND HP-255, RO, "DETERMINATION OF
WATER POTENTIAL USING THE DECAGON CX-2 SAMPLES." AND HP-255, RO, "DETERMINATION
WATER POTENTIAL USING THE DECAGON CX-2 WATER ACTIVITY SYSTEM."
A Y P

ACQN/DEVI LOCATION : OSGS HYDROIOGIC RESEARCH FACILITY, NTS, NV 
*GS950608312231.007 PHYSICAI PROPERTIES, WATER CONTENT AND WATER POTENTIAL FROM BOREHOLE USW NRG-6, 19 MAR 94 TO 27 MAR 95

$03 / 19 / 95-03 / 27 / 95$

ACON/DEVI IOCATION : OSGS HR

*GS950608312231.008 MOISTURE RETENTION DATA AND CURVE FITS FROM BOREHOLES USW UZ-N27 AND OE-25 OZ\#16.

$01 / 01 / 95-05 / 17 / 95$

ACQN/DEVL LOCATION : USGS HRE, AREA 25, NTS, NV
HP-229, R2 AND R3, "DETERMINATION OF WATER A Y P CONTENT AND PHYSICAL PROPERTIES FOR LABORATORY ROCK SAMPLES," AND HP-255, RO, "DEVELOPMENT OF WATER POTENTIAL OSING THE DECAGON CX-2 WATER ACTIVITY SYSTEM.

HP-229,R3, "DETERMINATION OF WATER CONTENT A Y AND PHYSICAI PROPERTIES FOR LABORATORY ROCK SAMPLES", HP-255, R0, "DEVELOPMENT OF WATER POTENTIAI USING THE DECAGON CX-2 WATER ACTIVITY SYSTEM". VAN GENUCHTEN CURVES WERE TO FIT DATA USING RETC.

07/13/94-09/10/94 DATA WERE ACQOIRED DORING AIR INJECTION A Y T Activity - 8.3.1.2.2.3.2

**GS950108312232.001 PRESSORE, TEMPERATURE AND MASS FLOW MEASUREMENTS FROM NRG-7A BOREHOLE AIR INJECTION TESTING BETWEEN 7/13/94 AND TESTING IN NRG-7A, OSING SCIENTIFIC NOTEBOOK PLAN HP-241T (SN-0033), AIR PERMEABILITY TESTING, AS DOCOMENTED IN VOL. 3, PP. 6-98. DATA WERE REDUCED TO ENGINEERING ONITS OF PRESSURE, TEMPERATURE AND MASS FLOW USING QUATTRO PRO.

ACQN/DEVL LOCATION : USW NRG-7A 
SITE CHARACTERIZATION PLAN BASELINE

DATA TRACKING NO.

TITLE/DESCRIPTION

**GS950108312232.002

PRESSURE, TEMPERATURE AND MASS FLOW MEASUREMENTS FROM NRG-6 BOREHOIE ATR INJECTION TESTING BETWEEN 10/11/94 AND $11 / 04 / 94$.

ACQN/DEVL IOCATION : OSW NRG-6

*GS950208312232.003 DATA, INCLODING WATER POTENTIAI,

PRESSURE AND TEMPERATURE, COLLECTED FROM BOREHOLES OSW NRG-6 AND OSW NRG-7A FROM INSTROMENTATION THRODGH MARCH 31, 1995 , AND FROM BOREHOLES OE-25 HRFOZP\#I AND HREO2P\# 3 A FROM OCTOBER 1. 1994, THRODGH MARCH 31, 1995

ACQN/DEVL LOCATION : OE-25 HRFOZP \#1 OE-25 HRFOZP \# 3 A USW NRG-6

*GS950508312232.004 IN-SITU BOREHOIE MONITORING DATA FOR USW NRG-7A AND OSW NRG-6, |YOCCA MOUNTAIN, NYE COONTY, NEVADA, PREPARED AND COMPILED BY J.P. ROOSSEAU, C.L. LOSKOT, M. KORZMACK, B.N. DEHOAN, K. THOMAS, A.J. GREENGARD.

ACQN/DEVL LOCATION : USGS, DENVER, CO

\section{ACON/DEVI PERIOD}

ACQN/DEVL METHOD

10/11/94-11/04/94 DATA WERE ACQOIRED DURING AIR INUECTION

TESTING IN NRG-6 USING SCIENTIFIC NOTEBOO PIAN HP-241T (SN-0033), AIR PERMEABILITY TESTING, AS DOCUMENTED IN VOL. 3 , PP. 99-141. DATA WERE REDUCED TO ENGINEERING ONITS OF PRESSORE, TEMPERATURE AND MASS FLOW USING QUATTRO PRO.

$10 / 01 / 94-03 / 31 / 95$ $10 / 28 / 94-03 / 31 / 95$ $11 / 17 / 94-03 / 31 / 95$

DATA WERE COILECTED USING THE HDAS SOFTWARE PROGRAM AND EXTRACTED TO A BINARY STROCTORE FOR DISPIAY.

$04 / 01 / 95-05 / 20 / 95$ 
SITE CHARACTERIZATION PIAN BASEIINE

DATA TRACKING NO.

TITLE/DESCRIPTION

*M09506NYE-CNTY.001 PNEUMATIC PRESSURE RECORDING FOR NRG-4 AND ONC-1

ACQN/DEVI LOCATION : NRG-4

Activity $-8.3 \cdot 1 \cdot 2 \cdot 2 \cdot 4.2$

**GS941108312242.002 PROTOTYPE PERCOLATION TEST: BASIC DATA REPORT ON WELDED TOFF CORE EXPERIMENTS, BY MAREK CIESNIK, JENNIFER CORTIS, AIAN BY MAREK CIESNIK, JENNIFER CORTIS, AIA
FIINT, DAVID HAMPSON AND FALAH THAMIR

ACON/DEVI LOCATION : USGS-WRD LAB, DENVER, CO

Activity - 8.3.1.2.2.4.4

* GS950308312244.001 AIR-PERMEABILITY TESTING PROGRAM - ESF, ALCOVE 1; SINGLE HOLE INJECTION TESTING, DATA COLLECTED BETWEEN 08/09/94 AND $11 / 14 / 94$

ACQN/DEVL LOCATION : ALCOVE 1, ESF

\section{ACQN/DEVL RERIOD}

05/01/95-06/01/95

$10 / 01 / 89-09 / 30 / 94$ CORE IF COLLECTED FROM THE COLUMNAR UNIT OF THE WATER POTENTIAI USING RICHARDS (BRAND NAME) PSYCHROMETERS AND WATER ACITIVITY NAME) PSYCHROMETERS AND WATER ACITIVITY METER. DETERMINATION OF WATER SATURATION RETENTION CURVES. DRYING RATE DETERMINED FOR VARIOUS WATER SATORATIONS.

DATA WERE ACOOIRED DORING AIR INJECTION TESTING IN ESE ALCOVE 1 USING SCIENTIF IC NOTEBOOK SN-0063, AIR PERMEABILITY

TESTING, AND REDÚCED TO ENGINEERING ONITS OF PRESSURE, TEMPERATURE AND MASS FLOW USING QUATTRO PRO.

DATA WERE COLIECTED USING THE HDAS SOFTWARE PROGRAM AND EXTRACTED TO A BINARY STROCTURE FOR DISPLAY. 

CM.

ACQN/DEVL LOCATION : $\begin{aligned} \text { N759961 (N) E557908 (N) } \\ \text { N759871(N) E557918(N) }\end{aligned}$

**GS921208312261.002 C.S.I. 21X DATALOGGER PRINTOUT FOR WELL OSW OZ-6S

ACQN/DEVL LOCATION : OSW OZ-6S

$\star \star G S 931008312261.002$

CARBON DIOXIDE, METHANE, CARBON-14, RESOLTS FROM OSW UZ-6, OSW UZ-6S, OSW OZ-N71, OSW OZ-N72, OSW OZ-N73, OSW OZ-N74, OSW UZ-N75, OSW OZ-N76, OSW OZ-N93, USW OZ-N94, AND OSW OZ-N95 FOR MARCH 1993.

ACQN/DEVL LOCATION : KROEGER GEOCHRON LABS, CAMBRIDGE, MA SO. METHODIST ONIV., DALIAS, TX

USGS HRF, NTS, NV

OSGS MOBILE LAB, AREA 25, NTS, NV

USGS NORTHEAST REGION RESEARCH LAB, RESTON, VA

OSGS STABLE ISOTOPE LAB, RESTON, VA

USGS UZ HYDROCHEMISTRY LAB, DENVER, CO 
SITE CHARACTERIZATION RLAN BASELINE

DATA TRACKING NO.

$\star \star G S 940608312261.002$

TITLE/DESCRIPTION

C.S.I. $21 \mathrm{X}$ DATALOGGER PRINTOUT FOR WELT OZ-6S PRIOR TO $5 / 3 / 89$

ACQN/DEVL LOCATION : OSW OZ-6S

**GS940708312261.004 SHOT-IN PRESSURE TEST DATA FROM DECEMBER 1992 TO FEBROARY 1994 FROM SELECT WELIS 1992 TO FEBROARY 1994 FROM SELECT WELLS
AND BOREHOIES AT YOCCA MOONTAIN, NEVADA

ACQN/DEVL LOCATION : OE-25 A\#4

$$
\begin{aligned}
& \text { OE-25 OZ\#16 } \\
& \text { OSW NRG-6 } \\
& \text { OSW OZ-13 } \\
& \text { OSW UZ-6 } \\
& \text { OSW UZ-6S }
\end{aligned}
$$

$\star \star G S 940708312261.005$

CARBON DIOXIDE, METHANE, CARBON 13/12,

AND OXYGEN $18 / 16$ RESOLTS FROM OSW OZ-6, OSW UZ-6S, OSW OZ-N27, USW OZ-N62, USW

OZ-N64 USW OZ-N75, OSW OZ-N93, USW OZ-N94, USW OZ-N95, OE-25 NRG\#2B， OE-25 NRG\#4, DE-25 NRG\#5, AND OSW NRG-6. THESE DATA WERE COLLECTED IN JANUARY 1994 AND MARCH 1994.

$01 / 18 / 94-03 / 15 / 94$ ATA ACQUIRED OSING THE FOLLOWING HYDROLOGIC PROCEDORES: GCP-15, R2, OXYGEN ISOTOPE ANALYSIS OF OPALINE SILICA, CHALCEDONY, AND QUARTZ; GCP-16, R4, CARBONATE CARBON AND OXYGEN ISOTOPE ANAIYSES; HP-160,R2 AND R2-M1, METHODS FOR ANAIYSES; HP-160, R2 AND R2-M1, METHODS FOR GAS CHROMATOGRAPHY: HP-176, R2, PROCEDURE GAS CHROMATOGRAPHY; HP-176, R2, PROCEDURE TO COILECT GAS SAMPLES AT SELECT DEP INTERVALS IN OPEN ONSATURATED 2ONE BOREHOLES; AND HP-256, R0, METHOD FOR
COLLECTING AND STORING $\mathrm{CO} 2$ GAS SAMPIES FROM BOREHOLE ATMOSPHERE OR FROM FREE AIR BY ABSORPTION IN A KOH SOLOTION.

ACQN/DEVL LOCATION : USGS BRANCH OF ISOTOPE GEOLOGY, DENVER, CO OSGS HRF, NTS, NV

USGS MOBILE LAB, AREA 25, NTS, NV 
DATA TRACKING NO.

TITLE/DESCRIPTION

ACON/DEVL PERIOD

$05 / 04 / 94-09 / 08 / 94$

CARBON DIOXIDE, METHANE, CARBON 14, AND CARBON 13/12 DATA FROM USW NRG-6 AND OS NRG-7 FOR MAY AND JUNE 1994; AND CARBON 14 DATA FROM OSW WELLS NRG\#5, OZ-6S, OZ-N27， OZ-N62， OZ-N64， రZ-N93， ठZ-N94, AND OZ-N95 FROM MARCH 1994.

ACQN/DEVL LOCATION : KROEGER GEOCHRON LABS, CAMBRIDGE, MA OSGS MOBILE IAB, AREA 25, NTS, NV USGS, STABIE ISOTOPE LAB, DENVER, CO

**GS950208312261.001 SHOT-IN PRESSORE TEST DATA FROM MAY 1994

TO SEPTEMBER 1994 FROM BOREHOLE OE-25

NRG\#4

$05 / 28 / 94-09 / 06 / 94$

ACQN/DEVL LOCATION : UE-25 NRG\#4
ACON/DEVL METHOD

$Y$ I

S

$\mathrm{E} D \mathrm{~N}$

THESE DATA WERE ACQUIRED USING STANDARD KROEGER GEOCHRON IAB PROCEDURES FOR CARBON 14 ANAIYSIS; GEOCHEMICAI PROCEDORES GCP-16,R4, CARBONATE CARBON AND OXYGEN ISOTOPE ANALYSES, AND GCP-33, RO, EXTRACTION OF SOIL GAS CO2 FOR STABLE ISOTORE ANALYSIS, AND HYDROLOGIC PROCEDURE HP-160, R2 AND R2-M1, METHODS FOR ANALYSIS OF SAMPIES FOR GAS COMPOSITION BY GAS CHROMATOGRAPHY GAS SAMPLES WERE COILECTED DSING HP-56, R3 AND R3-M1, GAS AND WATER VAPOR SAMPIING FROM AND WATER VAPOR SAMPIING FROM ONSATORATED 20 ONE TIST HOIES AND HP-176 PROCEDORE TO COLIECT GAS SAMPLES AT OEIECTED DEPTH INTERVALS IN OPEN ONSATURATED ZONE BOREHOLES PROCEDURE HP-257, RO, METHOD TO MEASURE SHOT-IN PRESSORE IN UNSATURATED ZONE BOREHOLES 
SITE CHARACTERIZATION PLAN BASELINE

DATA TRACKING NO.

TITLE/DESCRIPTION

Act1vity - 8.3.1.2.2.7.1

* GS911208312271.011 ANALYSIS OF CO2 CONCENTRATION OF SYRINGE SAMPIES TAKEN DURING OSW OZ-1 BOREHOLE GAS SAMPIING, SEPTEMBER, 1988

ACQN/DEVL LOCATION : OSGS MOBILE LAB, NTS, NV

**GS930408312271.014 ANALYSIS OF CO2 CONCENTRATION OF SYRINGE SAMPLES TAKEN DURING OSW OZ-1 BOREHOIE GAS SAMPLING, MAY, 1989, THRO JAN., 1991 .

ACQN/DEVL LOCATION : OSGS MOBILE LAB, NTS, NV

Activity - 8.3.1.2.2.7.2

**GS930608312272.002 PERMEABILITY AND PORE-FLOID CHEMISTRY OF THE BOLLFROG TUFF IN A TEMPERATORE GRADIENT: SUMMARY OF RESULTS BY U. BYERLEE, C. MORROW, AND D. MOORE.

ACQN/DEVL LOCATION : OSGS, DENVER, CO
ACON/DEVI, PERIOD

ACQN/DEVL METHOD

$09 / 08 / 88-09 / 16 / 88$

OSGS-HP-160,RO, METHODS FOR COLLECTION AND A N $P$ ANALYSIS OF SAMPLES FOR GAS COMPOSITION BY GAS CHROMATOGRAPHY

05/22/89-01/31/91 HP-160,R0, METHODS FOR COLLECTION AND

ANALYSIS OF SAMPIES FOR GAS COMPOSITION BY

GAS CHROMATOGRAPHY, AND HP-160,R1, METHODS

FOR ANAIYSIS OF SAMPIES FOR GAS

COMPOSITION BY GAS CHROMATOGRAPHY.

SAMPIES ARE DESTROYED IN ANALYSIS

SEVERAI SAMPIES ARE TAKEN AT EACH DEPTH IN HOLE OZ-1. EACH SAMPIING TRIP IS AN AID IN DETERMINING PUMPING EFFICIENCY.

$01 / 01 / 82-01 / 01 / 83$

VARIATIONS IN PERMEABILITY WERE DETERMINED D N C FROM MEASURED CHANGES IN THE MASS FLOW RATE OVER A CONSTANT PORE-PRESSURE

DIFFERENIIAU. PORE-FLOID CHEMISTRY ANALYSES INCLUDE: SILICA BY STANDARD SPECTROPHOTOMETRIC METHODS, CATIONS BY ATOMIC ABSORPTION, TOTAL DISSOLVED

INORGANIC CARBON BY CARBON ANALYZER,

ANIONS BY ION CHROMATOGRAPHY, DISSOLVED SPECIES OSING SOLMNEQ PROGRAM (KHARAKA ET AI, 1973). COMPIETE BIBLIOGRAPHIC

CITATIONS IN REPORT. 
DATA TRACKING NO.

TITLE/DESCRIPTION

ACQN/DEVI PERIOD

ACQN/DEVL METHOD

$01 / 01 / 83-01 / 01 / 84$ OF THE TOPOPAH SPRING MEMBER OF THE

PAINTBROSH TOFF NEVADA TEST SITE: PART

II, BY D.E. MOORE, C.A. MORROW, AND J.D. BYERLEE.

ACQN/DEVI LOCATION : USGS, MENLO PARK, CA

Activity - 8.3.1.2.2.8.1

* GS950308312281.001 DATA TRANSFER TO THE EARTH VISION MODEL BY G.S. BODVARSSON AND M. BANDORRAGA.

$12 / 01 / 94-01 / 31 / 95$

HYDROGEOLOGICAL PARAMETERS AND GEOLOGIC DATA WERE INPOT TO A 2-D AND 3-D MODEI. SIMOLATIONS WERE PERFORMED OSING THE INTEGRAI FINITE-DIFFERENCE COMPOTER CODE TOUGH2 WITH OUTPOTS OF "BASE CASE" PERMEABILITY, POROSITY, AND VAN GENUCHTEN PARAMETER DISTRIBUTIONS. THE OUTPUT DATA FILES PROVIDE THE SIMULATED ELOIDS

POTENTIAI FIELDS, INCLODING CAPILLARY PRESSURES AND SATURATIONS.

ACQN/DEVL LOCATION : LAWRENCE BERKELEY LABORATORY, BERKELEY, CA 


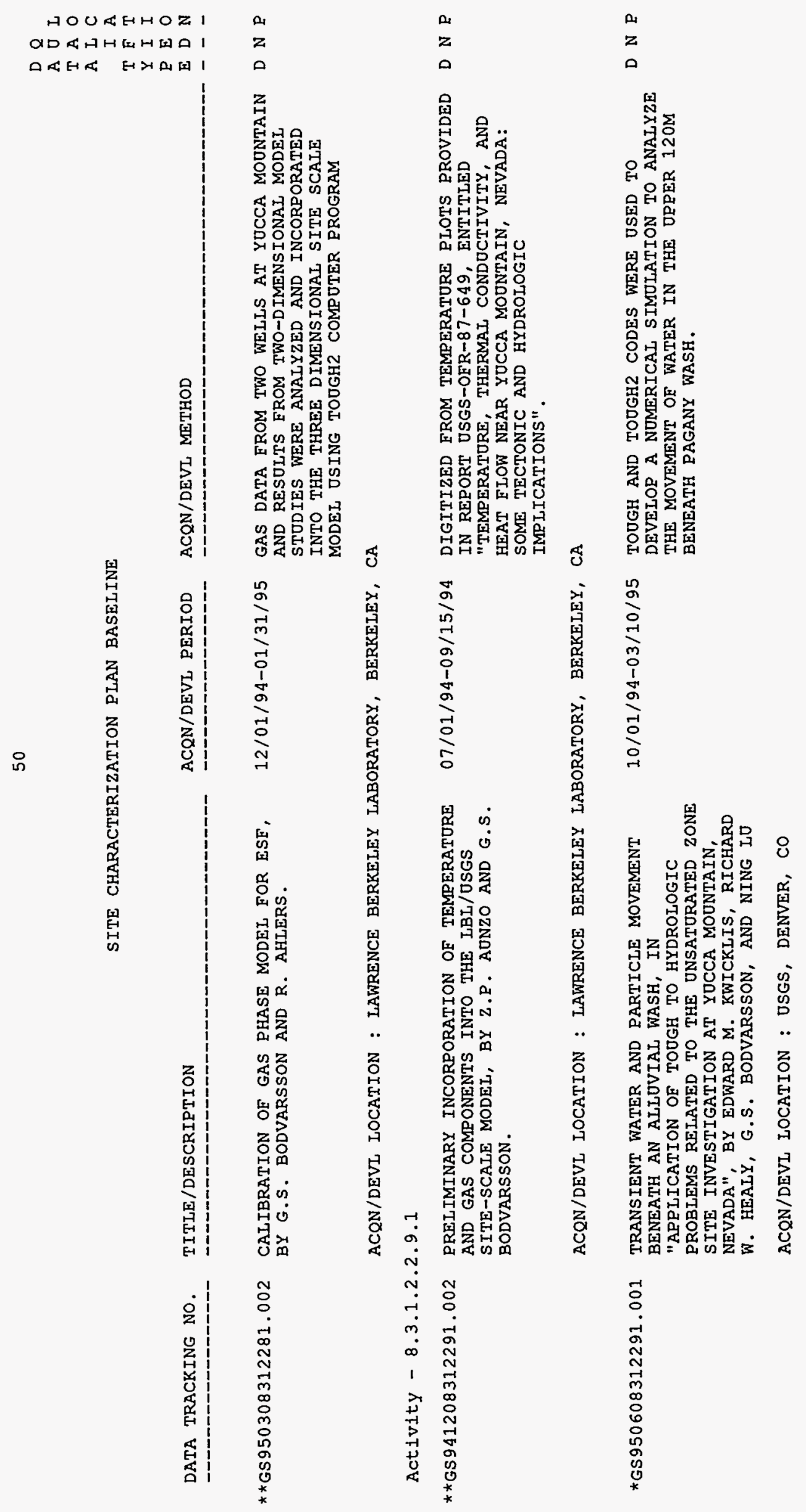


DATA TRACKING NO.

TITLE/DESCRIPTION

ACQN/DEVL PERIOD

ACON/DEVI METHOD

Activity - 8.3.1.2.2.9.3

**GS940908312293.002 THE DEVELOPMENT OF THE LBI/USGS THREE-DIMENSIONAL SITE-SCALE MODEL OF YUCCA MOUNTAIN, NEVADA, BY C. WITTWER, G. CHEN, G.S. BODVARSSON, M.P. CHORNACK

09/21/93-05/30/94 DATA DEVEIOPMENT BY USE OF TOOGH2 COMPOTER D N P CODE. THE VAN GENOCHTEN PARAMETERS WHICH ARE OSED IN FRACTORE HYDROLOGY ARE DERIVED FROM RELATIVE PERMEABIIITY AND WATER A.L. FLINT, L.E. FLINT, E.M. KWICKLIS, RETENTION.

AND R.W. SPENGIER

ACQN/DEVL LOCATION : LAWRENCE BERKELEY LABORATORY, BERKELEY, CA

Activity - 8.3.1.2.3.1.2

**GS921008312312.021 WATER IEVELS IN CONTINUODSLY MONITORED WELLS IN THE YOCCA MOONTAIN AREA, NEVADA, 1989 BY D.H. LOBMEYER, R.R. LUCKEY AND D.J. BORKHARDT

ACQN/DEVI LOCATION : USGS, DENVER, CO

**GS940208312312.002 WATER-IEVEL ALTITODE DATA FROM WELLS IN THE YOCCA MOONTAIN AREA, NEVADA, 1992.

ACQN/DEVI LOCATION : OSGS, DENVER, CO

**GS950108312312.001 WATER-LEVEL ALTITUDE DATA FROM THE PERIODIC NETWORK, FOURTH QOARTER 1994.

ACQN/DEVI LOCATION : TEST WELI B

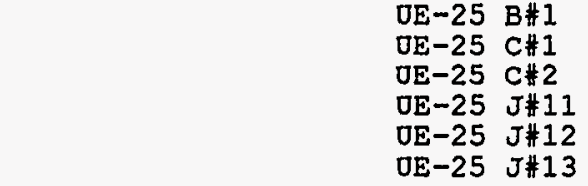

01/01/90-10/07/92 RAW TRANSDUCER OUTPUT DATA CONVERTED TO WATER-IEVEL ALTITUDE ABOVE SEA LEVEL USING STANDARD STATISTICAL METHODS DESCRIBED IN THE REPORT.

01/01/93-02/08/94 RAW TRANSDUCER DATA AND MANOAI

DEPTH-TO-WATER DATA CONVERTED TO ALTITUDE

OF THE WATER TABLE ABOVE SEA LEVEL DSING

STANDARD STATISTICAL TECHNIOUES.

10/01/94-12/31/94 HP-25,R2, "METHOD FOR MEASURING

DEPTH-TO-WATER WITH A CABLE ONIT", AND HP-75, R1 AND R2, "METHOD FOR MEASURING DEPTH-TO-WATER IN WELLS USING REELED STEEI TAPES LONGER THAN 1,000 FEET".

WATER-LEVEL ALTITODE CALCOLATED OSING STANDARD MATHEMATICAL TECHNIQOES. 
SITE CHARACTERIZATION PLAN BASELINE

(1)

OE-25
WT\#12
OE-25 WT\#13
UE-25 WT\#15
OE-25 WT\#16
OE-25 WT\#17
OE-25 WT\#18
OE-25 WT\#6
USW G-2
USW G-3
USW H-1
USW H-3
USW H-6
USW OZ-14
USW VH-1
USW WT-11
USW WT-2
USW WT-7

*GS950408312312.003 WATER-LEVEL ALTITUDE DATA FROM THE PERIODIC NETWORK, FIRST QUARTER 1995.

\begin{tabular}{|c|c|}
\hline ACQN/DEVI LOCATION : & 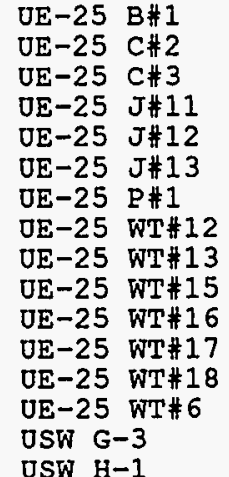 \\
\hline
\end{tabular}

01/01/95-03/31/95 HP-25, R2, "METHOD FOR MEASURING DEPTH-TO-WATER WITH A CABLE ONIT," AND

A N P HP - 75, R2, DEPTH-TO-WATER IN WELIS OSING REELED STEEL TAPES IONGER THAN 1,000 FEET." WATER-LEVEI ALTITODE CALCOIAATED OSING STANDARD MATHEMATICAL TECHNIOOES. 
SITE CHARACTERIZATION PLAN BASEIINE

DATA TRACKING NO. TITLE/DESCRIPTION ACON/DEVL PERIOD

USW $\mathrm{H}-4$

USW H-5

OSW SD-7

OSW OZ-14

OSW VH-1

OSW WT'-11

USW WT-2

*GS950508312312.004 WATER-LEVEL ALTITUDE DATA FROM THE CONTINUOUS NETWORK, 1994.

ACQN/DEVL LOCATION : OE-25 P\#1

OE-25 WT\#13

OE-25 WT\#14

OE-25 WT\#3

DE-25 WT\#4

OSGS, DENVER, CO

OSW G-2

USW G-2

OSW G-3

OSW $H-1$

USW $\mathrm{H}-3$

USW $\mathrm{H}-4$

OSW $\mathrm{H}-5$

OSW $\mathrm{H}-6$

OSW WT-1

סSW WT-10

USW WT-11

एSW WT-2
01/01/94-05/15/95 TRANSDOCER DATA COLLECTED ACCORDING TO HP-60, R3-M1, "METHOD FOR MONITORING WATER LEVEI CHANGES OSING PRESSORE TRANSDOCERS AND PRESSORE TRANSMITTERS." TRANSDOCER DATA CONVERTED TO ALTITUDE OF WATER TABLE ABOVE SEA LEVEL USING CALIBRATION

REGRESSION EOUATIONS AND DEPTH TO WATER

DATA COLIECTED EITHER WITH HP-60 R3 (M1)

DATA COLLECTED EITHER WITH HP-60 R3 (M1)
OR HP 75, R1 AND R2, "METHOD FOR MEASORING OR HP-75, R1 AND R2, "METHOD FOR MEASORING LONGER THAN 1,000 FEET. 
SITE CHARACTERIZATION PLAN BASELINE

DATA TRACKING NO. TITLE/DESCRIPTION

*GS950508312312.005 POTENTIOMETRIC-SURFACE MAP, 1993, YOCCA MOONTAIN AND VICINITY, NEVADA, BY PATRICK TUCCI AND D.J. BURKHARDT.

ACQN/DEVL LOCATION : USGS, DENVER, CO

Activity - 8.3.1.2.3.1.3

**GS911108312313.009 GEOHYDROLOGY OF ROCKS PENETRATED BY TEST WELL OSW H-6, YOCCA MOONTAIN, NYE COONTY, NEVADA, BY R.W. CRAIG AND R.L. REED.

ACQN/DEVL LOCATION : OSGS, DENVER, CO

**GS950108312313.003 BAROMETRIC PRESSORE DATA FROM OE-25 C\#3, NEVADA, $7 / 15 / 93$ THROUGH $8 / 17 / 93$.

$07 / 15 / 93-08 / 17 / 93$ ACQN/DEVL LOCATION : OE-25 C\#3
ACQN/DEVL PERIOD

ACQN/DEVL METHOD

$\begin{array}{llll}D & Q & & -1 \\ A & 0 & L\end{array}$

T A 0

A I C

I $A$

T

$Y$ I

\begin{tabular}{llll} 
E & D & N \\
\hline & -1 & -
\end{tabular}

$10 / 03 / 94-03 / 16 / 95$ POTENTIOMETRIC SORFACE CREATED USING MAINLY 1993 AVERAGE WATER LEVELS. WATER LEVELS WERE CONTOURED WITH A 20-METER CONTOOR INTERVAL, WITH ADDITIONAL 0.5-METER CONTOURS IN THE SMALL-GRADIENT AREA SOOTHEAST OF YOCCA MOUNTAIN.

$01 / 01 / 88-02 / 01 / 89$

TRANSMISSIVITY BY 1) THEIS METHOD 2)

STRAIGHT-IINE SOLUTION WITH DOAL-POROSITY MODEL. HORIZONTAL HYDRAULIC CONDUCTIVITY BY COMPOTATION OF TRANSMISSIVITY DIVIDED BY TEST-LENGTH INTERVAI. GRODND-WATER ANALYSIS USING OSGS STANDARD METHODS.

REIATIVE POROSITY DEDUCED FROM WEIL LOGS.

PERMEABIIITY DEDOCED BY INDIRECT EVIDENCE.

DATA COLLECTED OSING HP-121, RO,

"INSTALIING AND RETRIEVING INFORMATION 


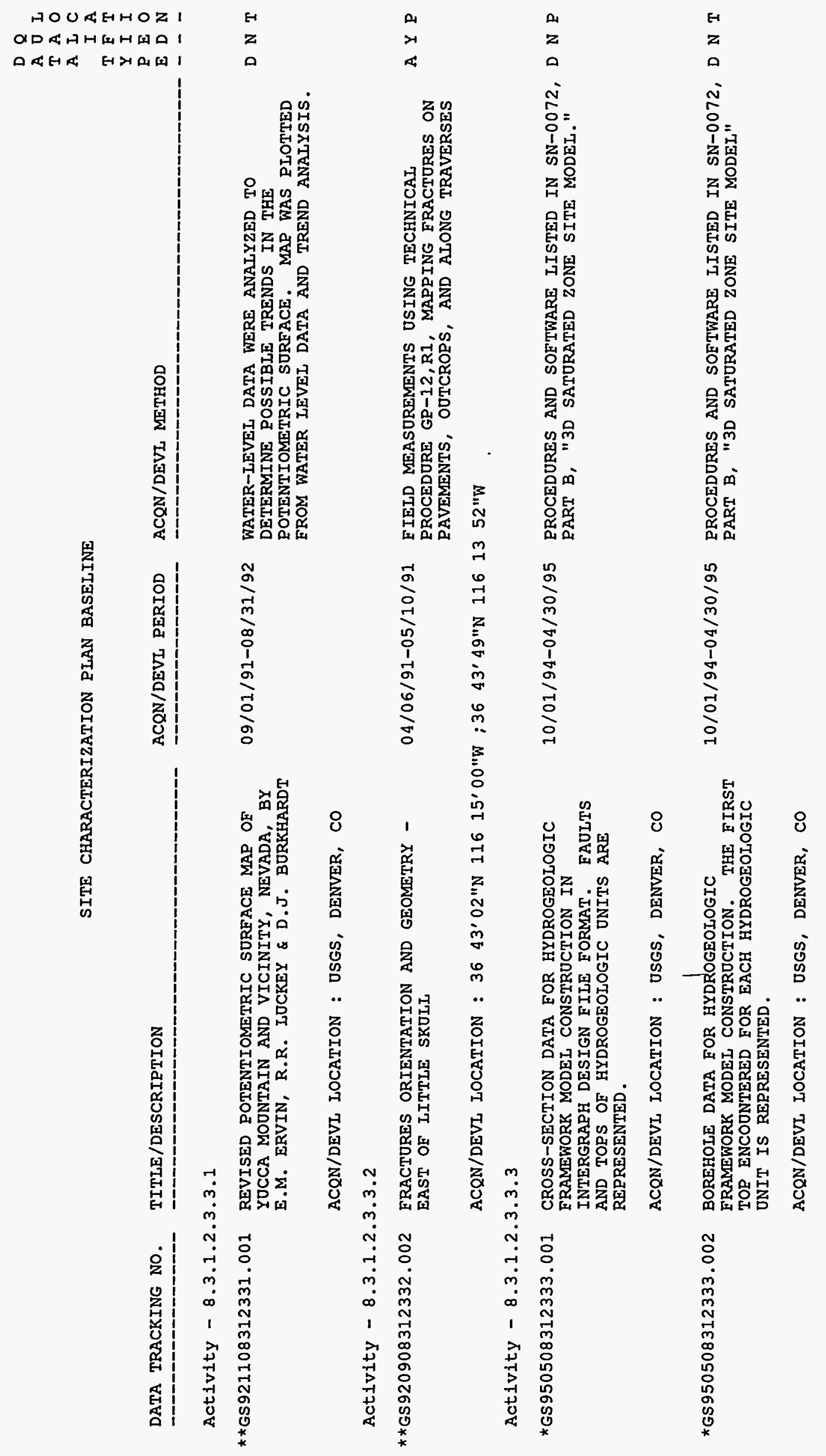


SITE CHARACTERIZATION PLAN BASELINE

DATA TRACKING NO.

TITLE/DESCRIPTION

Activity - 8.3.1.3.2.1.2

* LA000000000110.002 MINERALOGIC SUMMARY OF YUCCA MOUNTAIN, NEVADA

ACQN/DEVL LOCATION : LANI

$\star \star$ IAO000000000111.002 MINERALOGY OF DRILL HOLES J-13,

OE-25A\#1, AND OSW G-1 AT YOCCA MOUNTAIN NEVADA

ACQN/DEVL LOCATION : IAANL

$\star \star$ LA000000000112.002 DETAILED PETROGRAPHIC DESCRIPTIONS AND MICROPROBE DATA FOR DRILL HOLES OSW-G AND OE25B-1H, YUCCA MOUNTAIN, NEVADA

ACQN/DEVL LOCATION : ILANL

**LA000000000113.002 PETROGRAPHY AND PHENOCRYST CHEMISTRY OF VOLCANIC ONITS AT YOCCA MOUNTAIN: A VOLCANIC ONITS AT YUCCA MOUNTAIN: SAMPIES

ACQN/DEVL LOCATION : LANL

$\star \star$ IAO00000000114.002 DETAILED PETROGRAPHIC DESCRIPTIONS AND MICROPROBE DATA FOR TERTIARY SILICIC VOLCANIC ROCKS IN DRILL HOLE OSW G-1, YUCCA MOUNTAIN, NEVADA

ACON/DEVL LOCATION : LANL
ACON/DEVI PERIOD

ACQN/DEVL METHOD

D $Q$

T A

A $I C$

$I A$

$T$ F T

$\begin{array}{lll}Y & I & I \\ P & E & O\end{array}$ E D $N$ ACQT/DEVI PERIOD

06/30/85-06/30/86 X-RAY POWDER DIFFRACTION ANALYSIS 
DATA TRACKING NO. FROM THE OE25A-1 DRIII SITE, YOCCA MOUNTAIN, NEVADA

ACON/DEVI IOCATION : ILANI

**IA000000000116.002 VARIATIONS IN AOTHIGENIC MINERALOGY AND SORPTION ZEOLITE ABUNDANCE AT YOCCA MOUNTAIN NEVADA, BASED ON STUDIES OF MOUNTAIN NEVADA, BASED ON

ACQN/DEVL LOCATION : LANL

**LA000000000117.002 PETROGRAPHY AND MINERAL CHEMISTRY OF ONITS OE THE TOPOPAH SPRING, CALICO HILLS AND CRATER FIAT TOFES, AND OIDER VOICANIC ONITS, WITH EMPHASIS ON SAMPLES FROM DRILL OSW G-1, YOCCA MOONTAIN NEVADA TEST SITE

ACQN/DEVL LOCATION : IANL
04/30/83-04/30/84 OPTICAL PETROGRAPHY, EIECTRON MICROPROBE ANAIYSIS, SCANNING ELECTRON MICROSCOPY, ANALYSIS, SCANNING ELECTRON

04/30/82-04/30/84 OPTICAL PETROGRAPHY AND ELECTRON MICROPROBE ANAIYSIS 
SITE CHARACTERIZATION PLAN BASELINE

DATA TRACKING NO.

TITLE/DESCRIPTION

Activity - 8.3.1.3.2.1.3

* $*$ LA000000000002.001 ELECTRON MICRORROBE ANALYSES OF FRACTURE-LINING MANGANESE OXIDE MINERAIS IN THE CRATER FLAT TUFF OF DRIIL CORE OSW- G-4.

ACQN/DEVI LOCATION : LANI

Activity - 8.3.1.3.2.2.1

*IA000000000094.001 PETROGRAPHY, MINERAIOGY, AND CHEMISTRY OF CALCITE-SILICA DEPOSITS AT EXILE HILI, NEVADA, IN COMPARISON WITH LOCAL SPRING DEPOSITS

ACQN/DEVI LOCATION : LOS ALAMOS NATIONAI LABORATORY

* $*$ IA000000000095.001 MINERALOGY AND TEMPORAI RELATIONS OF COEXISTING AOTHIGENIC MINERALS IN ALTERED SILICIC TOFFS AND THEIR OTILITY AS POTENTIAL LOW-TEMPERATURE DATEABIE

MINERALS

ACQN/DEVL IOCATION : LANL

\section{ACQN/DEVI PERIOD}

01/01/86-12/31/89 ELECTRON MICRORROBE DATA.

D N T

OPTICAL PETROGRAPHY, X-RAY DIFFRACTION, ELECTRON MICROPROBE, SCANNING EIECTRON MICROSCOPY, X-RAY FIUORESCENCE, INSTROMENTAL NEOTRON ACTIVATION ANALYSIS, LOW-TEMPERATURE ASHING, AND ION CHROMATOGRAPHY

$02 / 01 / 92-02 / 01 / 93$

COEXISTING FINE-GRAINED AUTHIGENIC SIIICATE MINERALS SEPARATED FROM ALTERED TOFFS IN MIOCENE AND OUATERNARY IACOSTRINE DEPOSITS WERE CHARACTERIZED BY X-RAY POWDER DIFFRACTION AND DATED BY THE $\mathrm{K} / \mathrm{AR}$ POWDER DIFFRACTION AND DATED BY THE K/AR MINERAIS FOR DETERMINING THE TIME OF

DIAGENESIS IN LOW TEMPERATORE SETTINGS. 
DATA TRACKING NO. TITIE/DESCRIPTION

*LA000000000101.001 CHEMICAL-TEXTURAL STUDIES OF ELEMENT MOBIIITY DORING ZEOLIZATION

ACQN/DEVL LOCATION : ILANL

Activity - 8.3.1.3.2.2.2

*LA000000000123.002 THERMODYNAMICS OF HYDRATION OF NA-, K-, AND CA- CIINOPTIIOIITE

ACQN/DEVL LOCATION : LANL

Activity - 8.3.1.3.5.1.1

**LA000000000012.002 MEASURED SOLUBIIITIES AND SPECIATIONS OF NEPTUNIOM, PLOTONIOM, AND AMERICIOM IN A TYPICAL GROUNDWATER (J-13) FROM THE YOCCA MOUNTAIN REGION

ACQN/DEVL LOCATION : LBL

**LA000000000033.002 MEASURED SOLUBILITIES AND SPECIATIONS FROM OVERSATORATION EXPERIMENTS OF NEPTONIUM, PIUTONIUM AND AMERICIOM IN OE25P\#1 WELL WATER FROM THE YUCCA MOUNTAIN PROJECT

ACQN/DEVL LOCATION : LAWRENCE BERKEIEY IABORATORY

\section{ACQN/DEVL PERIOD}

$09 / 16 / 82-07 / 21 / 94$ ACQN/DEVL METHOD
EIECTRON MICRORROBE, SCANNING ELECTRON MICROSCOPE, PETROGRAPHIC TEXTURAI ANAIYSIS, AND GEOPETAL ORIENTATION MEASOREMENT

$05 / 03 / 94-01 / 31 / 95$ THERMODYNAMIC ANALYSIS OF EQDILIBR:TOM WATER CONTENT OF CLINOPTILOLITE AS MEASORED BY THERMOGRAVIMETRY

10/01/91-08/24/92 THERMODYNAMIC DATA DETERMINED BY SOLOBIIITY MEASUREMENT FROM OVERSATORATION SOLUBILITY MEASUREMENTS FROM 
DATA TRACKING NO.

TITLE/DESCRIPTION

Activity - 8.3.1.4.1.2

**TMBH-VARIOUS95.001

DIRECTIONAL/DEVIATION GYRO SORVEYS OF THE FOLLOWING BOREHOLES: UE-25 NRG-2 OE-25 NRG-2A, UE-25 NRG-2B, OE-25 NRG-2D, OE-25 NRG-3, OE-25 NRG-4, OE-25 NRG-5, USW NRG-6, OSW NRG-7/7A, OSW WT-2, UE-25 OZ-16, AND USW OZ-1. DATA CONSISTS OF 3.5" DISKETTES CONTAINING ASCII FORMAT DATA FILES.

ACON/DEVL LOCATION : N771276(N) E560221(N) $0^{\prime}$ TO 1180' N760661 (N) E561924(N) O' TO 2029' N768880 (N) E562984(N) O' TO 1409' $\mathrm{N} 766725(\mathrm{~N}) \mathrm{E} 564187(\mathrm{~N}) 0^{\prime}$ TO $1089^{\prime}$ $\mathrm{N} 767890(\mathrm{~N}) \mathrm{E} 564770(\mathrm{~N}) 0^{\prime}$ TO $1340^{\prime}$ N760535(N) E564858(N) O' TO 1643, N767080 (N) E566820 (N) $0^{\prime}$ TO 710' N766251 (N) E568318(N) 8, TO 315' N765700(N) E569001 (N) $0^{\prime}$ TO 255' N765700 (N) E569001(N) $0^{\prime}$, TO $255^{\prime}$ N765801(N) E569150(N) 11' TO 115' $\mathrm{N} 765764(\mathrm{~N})$ E569162(N) $0^{\prime}$ TO 283'
$\mathrm{N} 765765(\mathrm{~N})$ E569214(N) $0^{\prime}$ TO $310^{\prime}$

*TMOE25NRG40095.001 DOWNHOLE ORIENTED COLOR VIDEO OF .UE-25 NRG-4 RON BY BARBOUR WELL SURVEYING CORP. TWO TAPES. TAPE \#1: 0 TO 724.78 $10 / 06 / 93-10 / 06 / 93$ TT (DOTNHOLE RUN) TAPE \#2.724.78 TO 0 FT. (OPHOLE RUN) .

ACQN/DEVI LOCATION : $\begin{aligned} & \text { N767080.21(N) E566819.99(N) ELEVATION: } \\ & 4099.48 \mathrm{FT}\end{aligned}$

ACQN/DEVL LOCATION : $\begin{aligned} & \text { N767080.21(N) E566819.99(N) ELEVATION: } \\ 4099.48 \mathrm{FT} & \end{aligned}$
ACQN/DEVL PERIOD

ACQN/DEVL METHOD

03/15/93-05/25/94 GEOPHYSICAI IOGGING DATA COITECTED OSING PROCEDURES AP-S. III.1-O AND YAP-SIII. 40, "YOCCA MOUNTAIN SITE CHARACTERIZATION PROJECT FIELD VERIFICATION OF GEOPHYSICAI LOGGING OPERATIONS"
VIDEO TAPE DATA COLLECTED USING PROCEDURES AP S.III.1-Q \& YAP-SIII. 4Q "YOCCA MOUNTAIN SITE CHARACTERIZATION PROJECT FIELD VERIFICATION OF GEOPHYSICAL LOGGING OPERATIONS" 
DATA TRACKING NO.

TITIE/DESCRIPTION

ACON/DEVI PERIOD

ACQN/DEVL METHOD

$10 / 06 / 93-10 / 06 / 93$

DOWNHOLE ORIENTED COLOR VIDEO OF OE-2

NRG-5 RON BY BARBOOR WELL SURVEYING

CORP. TWO TAPES. TAPE \#1: 0 TO 880 FT.

(DOWNHOLE RON). TAPE \#2: 880 TO 1348 FT

(DOWNHOLE RON) AND 1348 TO 0 FT. (UPHOLE

RON) .

ACQN/DEVI LOCATION : N767889.61(N)

ELEVATION: 4106.66 FT

*TMUSWG20000095.001 GEOPHYSICAI LOGGING RECORD PACKAGE (SEGMENT \#1) FOR BOREHOLE USW G-2. (SEGLEN 1 ) TOR BOREHOLE USW G-2. M\&O/GEOPHYSICS JOB ID \# 94-G2-01. SCHLOMBERGER LOGS: PHASOR

INDUCTION-GAMMA RAY (DITE/GR),

ACCELERATOR NEUTRON POROSITY-GAMMA RAY

(APS/GR), DUAL ROROSITY NEUTRON-GAMMA

RAY (CNTG/GR), LITHODENSITY-GAMMA RAY

(LDTD/GR), SIDEWALI NEUTRON

POROSITY-GAMMA RAY (SNP/GR). DATA

CONSISTS OF FIEID PRINTS (PAPER) AND

FIELD FILMS (MYLAR). USGS LOG:

CONTINOOUS TEMPERATORE LOG. DATA

CONSISTS OF FIELD RRINT (RAPER) AND DATA

DISKETTE (3-1/2 INCH FLOPPY).

ACQN/DEVI LOCATION : DEPTH $=0^{\prime}$ TO $2640^{\circ}$

N778, 824.18(11)

$\mathrm{N} 778,82$
$5098.4^{\prime}$

$E 560,503.88(\mathrm{~N})$

$01 / 04 / 95-02 / 01 / 95$

GEOPHYSICAL LOGGING DATA COLLECTED USING

PROCEDORE YAP-SIII. 4Q "YOCCA MOONTAIN SITE CHARACTERIZATION PROJECT FIELD

IOGGING OPERATIONS"

AP S.III.1-Q \& YAP-SIII.4Q "YUCCA MOUNTAIN

VERIFICATION OF GEOPHYSICAI IOGGING OPERATIONS"

ELEVATION $=$ 
SITE CHARACTERIZATION PLAN BASELINE

DATA TRACKING NO.

TITLE/DESCRIPTION

ACON/DEVL PERIOD

ACQN/DEVL METHOD

03/18/93-03/18/93 VIDEO TAPE DATA COLLECTED BY RATHEON SERVICES NEVADA (RSN) USING APPROVED RSN QA PROCEDURES. NRG-6 RUN BY BARBOUR WELI SURVEYING CORP. THREE TAPES. TAPE \#1: 0 TO 953 FT. (DOWNHOLE RUN). TAPE \#2: 950 TO $1093 \mathrm{FT}$. (DOWNHOLE RUN) AND 1093 TO 910 FT. (OPHOLE RUN). TAPE \#3: 911 TO 0 FT. (UPHOLE RUN).

ACQN/DEVL LOCATION : $\begin{aligned} & \text { N766726.28(N) E564187.17(N) } \\ 4092.20 \mathrm{FT} & \text { ELEVATION: }\end{aligned}$

*TMOSWNRG7A0095.001 DOWNHOIE ORIENTED COLOR VIDEO OF USW NRG-7/7A RON BY BARBOUR WELL SURVEYING NRG-7/7A RON BY BARBOUR WELL SURVEYING
CORP. THREE TAPES. TAPE \#1: 0 TO 843 CORP. THREE TAPES. TAPE \#1: 032 TO FT. (DOWNHOLE RUN) D TAPE \#2: 832 TO
1404 FT. (DOWNHOLE RUN) AND 1404 TO 769 FT. (OPHOLE RON). TAPE \#3: 769 TO 0 FT. (OPHOLE RON).

ACQN/DEVL LOCATION : N768880.11(N) 4207.17 FT
06/01/94-06/01/94 VIDEO TAPE DATA COLLECTED USING PROCEDURES A Y $P$ AP S.III.1-Q \& YAP-SIII. $4 Q$ "YUCCA MOUNTAIN VERIFICATION OF GEOPHYSICAL LOGGING OPERATIONS" SITE CHARACTERIZATION PROJECT FIELD

ACQN/DEVI LOCATION : $\begin{aligned} & \text { N768880.11(N) E562983.99(N) ELEVATION: } \\ & 4207.17 \text { FT }\end{aligned}$


DATA TRACKING NO.

Activity - 8.3.1.4.2.1.1

**GS910708314211.011 SR AND ND ISOTOPIC DATA AND RB, SR, ND AND SM CONCENTRATIONS FROM DRILI CORE SPECIMENS FROM OE-25A \#1. THESE DATA ARE

$07 / 01 / 90-11 / 30 / 90$ GCP-12, RB-SR ISOTORE GEOCHEMISTRY AND GCP-21, SM-ND ISOTOPE GEOCHEMISTRY SUPERSEDED BY DATA IDENTIFIED BY DTN GS950308314211.015.

ACQN/DEVL LOCATION : DSGS, DENVER, CO

**GS940308314211.011 TABLE OF CONTACTS FOR THE TIVA CANYON TOFF IN BOREHOLE USW OZ-N38, VERSION (S) TOFF IN BOREHOLE OSW
1. (N), BY T. MOYER

$02 / 01 / 94-03 / 04 / 94$ THESE DATA WERE ACQUIRED FROM ANAJYSIS O CORE OSING SCIENTIFIC PLAN SN-0001 SIRATIGRAPHIC SIODIES FROM GEOLOGIC DESCRIPTION OE CORE, BIT COTTINGS, AND OOTCROP

ACQN/DEVI LOCATION : SAMPLE MANAGEMENT FACILITY

**GS940308314211.016 TABLE OF CONTACTS FOR THE TIVA CANYON TOFF IN BOREHOLE OSW OZ-N64, VERSION (S) 1. (N), BY T. MOYER AND J, GESIIN

ACON/DEVL LOCATION : SAMPIE MANAGEMENT FACILITY

**GS940308314211.017 TABLE OF CONTACTS FOR THE TIVA CANYON TUFF IN BOREHOLE OE-25 OZN\#63,

VERSION (S) 1. (N), BY T. MOYER AND J. GESLIN

ACON/DEVL LOCATION : SAMPLE MANAGEMENT FACIIITY
$03 / 01 / 94-03 / 25 / 94$

03/01/94-03/25/94 THESE DATA WERE ACOUIRED FROM ANALYSES O CORE USING SCIENTIFIC PLAN SN-0001, STRATIGRAPHIC STODIES FROM GEOIOGIC DESCRIPTION OE CORE, BIT CUTTINGS, AND ODTCROP

THESE DATA WERE ACQOIRED FROM ANALYSES OF CORE USING SCIENTIFIC PLAN SN-0001

STRATIGRAPHIC STODIES FROM GEOLOGIC DESCRIPTION OF CORE, BIT CUTTINGS, AND OUTCROP 
SITE CHARACTERIZATION PLAN BASELINE

DATA TRACKING NO.

TITLE/DESCRIPTION

**GS940308314211.018

TABLE OF CONTACTS FOR THE TIVA CANYON

TOFF IN BOREHOLE OSW OZ-N36, VERSION (S)

1. (N), BY T. MOYER AND J. GESIIN

ACON/DEVI LOCATION : SAMPLE MANAGEMENT FACILITY

**GS940308314211.019 TABLE OF CONTACTS FOR THE TIVA CANYON

TOFF IN BOREHOLES USW OZ-N15, OSW

UZ-N16, AND USW UZ-N17, VERSION(S) 1 . (N)

, BY T. MOYER AND J. GESIIN THESE DATA WERE ACQUIRED FROM ANALYSE
CORE USING SCIENTIEIC PLAN SN-0001,
STRATIGRAPHIC STUDIES FROM GEOLOGIC STRATIGRAPHIC STODIES FROM GEOIOGIC
DESCRIPTION OF CORE, BIT COTTINGS, AND OUTCROP

ACQN/DEVL LOCATION : SAMPLE MANAGEMENT FACILITY

**GS940608314211.022 IITHOSTRATIGRAPHIC DATA FOR THE PROW PASS TOFF IN OSW G-1, G-2, GU-3, AND G-4, OE-25 A\#1, OE-25 C\#1，C\#2，AND C\#3, AND FIELD OBSERVATIONS FROM RAVEN CANYON AND PROW PASS, BY T.C. MOYER.

ACQN/DEVL LOCATION : USGS, LAS VEGAS, NV

**GS940608314211.023 IITHOSTRATIGRAPHIC DATA FOR THE PROW PASS TUFF IN UE-25 UZ\#16 BY T.C. MOYER. THE CONTACT DEPTH BETWEEN THE CALICO HILLS FORMATION AND THE PROW PASS TUFE IN THIS SEGMENT SUPERSEDE DATA

PREVIOUSLY IDENTIFIED BY DTN

GS931208314211.047 AND

GS940308314211.009. DATA FOR PAINTBRUSH GROOP BEDDED TOFE ONITS TPBT3 AND TPBT4 IN THIS SEGMENT HAVE BEEN SOPERSEDED BY DATA IDENTIFIED BY DTN GS950108314211.008.

ACQN/DEVL LOCATION : OSGS, LAS VEGAS, NV
03/03/94-06/09/94 THESE DATA WERE ACQUIRED FROM ANALYSES OF CORE AND FIELD OBSERVATIONS USING SCIENTIFIC PLAN SN-0001, "STRATIGRAPHIC STUDIES FROM GEOLOGIC DESCRIPTION OF CORE BIT CUTTINGS, AND OUTCROR".

$04 / 18 / 94-05 / 09 / 94$ THESE DATA WERE ACQUIRED FROM ANALYSES OF CORE AND FIELD OBSERVATIONS OSING SCIENTIFIC PLAN SN-0001, "STRATIGRAPHIC STUDIES FROM GEOLOGIC DESCRIPTION OF CORE, BIT COTTINGS, AND OUTCROP".

T

CORE USING SCIENTIFIC PLAN SN-0001,

DESCRIPTION OF CORE, BIT COTTINGS, AND ODTCROP

\section{A Y T}

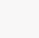


DATA TRACKING NO.

* $\star$ GS940608314211.024 IITHOSTRATIGRAPHIC DATA FOR THE PROW PASS TOFF TN OSW OZ-14 THE CONTACT ALTTTODES FOR THE PROW PASS TOEF ARE SURERSEDED BY THOSE FOOND IN THE DATA SEGMENT IDENTIFIED BY DTN GS940908314211.043.

ACQN/DEVL LOCATION : USGS, ILAS VEGAS, NV

**GS940608314211.025 LITHOSTRATIGRAPHIC DATA FOR THE CALICO HILLS FORMATION IN USW G-1, G-2, GU-3, AND G-4, OE-25 A\#1, OE-25 C\#1, C\#2, AND FIELD OBSERVATIONS FROM BUSTED BOTTE AND PROW PASS, BY J.K. GESIIN.

ACQN/DEVL LOCATION : USGS, LAS VEGAS, NV

**GS940608314211.026 LITHOSTRATIGRAPHIC DATA FOR THE CALICO HILLS FORMATION IN OE-25 OZ\#16 BY J.K. GESLIN. THESE DATA SOPERSEDE A PORTION OF THE DATA PREVIOUSLY IDENTIFIED BY DTN GS931208314211.047.

ACQN/DEVL LOCATION : USGS, LAS VEGAS, NV

**GS940608314211.027 IITHOSTRATIGRAPHIC DATA FOR THE CALICO HIILS FORMATION IN OSW OZ-14 BY J.K. GESIIN.

ACQN/DEVL LOCATION : USGS, LAS VEGAS, NV
$07 / 05 / 94-07 / 06 / 94$ THESE DATA WERE ACQUIRED EROM ANALYSES OF CORE AND FIELD OBSERVATIONS OSING SCIENTIFIC PLAN SN-0001, "STRATIGRAPHIC STODIES FROM GEOLOGIC DESCRIRTION OF CORE, BIT CUTTINGS, AND OUTCROP"

$03 / 03 / 94-05 / 25 / 94$ THESE DATA WERE ACODIRED FROM ANALYSES O CORE AND FIEID OBSERVATIONS OSING

SCIENTIFIC PLAN SN-0001, "STRATIGRAPHIC STODIES FROM GEOLOGIC DESCRIPTION OF CORE BIT COTTINGS, AND OOTCROP".

$04 / 18 / 94-04 / 20 / 94$ THESE DATA WERE ACQOIRED FROM ANALYSES OF CORE AND FIELD OBSERVATIONS OSING SCIENTIFIC PIAN SN-0001, "STRATIGRAPHIC STODIES FROM GEOLOGIC DESCRIPTION OF CORE, BIT CUTTINGS, AND OOTCROP"

$04 / 19 / 94-07 / 06 / 94$ THESE DATA WERE ACQUIRED FROM ANAIYSES OF CORE AND FIELD OBSERVATIONS OSING SCIENTIFIC PIAN SN-0001, "STRATIGRAPHIC STODIES FROM GEOIOGIC DESCRIPTION OF CORE BIT COTTINGS, AND OUTCROP". 
DATA TRACKING NO.

$\star \star G S 940708314211.034$ MISCELLANEOUS IITHOSTRATIGRAPHIC CONTACTS IN NON-QUALIFIED BOREHOLES (USW G-2 AND G-4, OE-25 A\#1), VERSION (S) 1. (N), BY T.C. MOYER

ACQN/DEVI LOCATION : SAMPLE MANAGEMENT FACILITY

**GS940708314211.035 MEASURED STRATIGRAPHIC SECTION ON THE EAST SIDE OF SOLITARIO CANYON (SECTION EAST SIDE OF SOLITARIO CANYON (SECTION
SC\#1), BY J.K. GESLIN AND T.C. MOYER

ACQN/DEVL LOCATION : N757634(N) E558253(N)

**GS940808314211.041 GRAPHICAL LITHOLOGIC LOG OF BOREHOLE OSW SD-9 FROM SORFACE TO THE BASE OF THE PAINTBRUSH GROUP, VERSION(S) $1 .(\mathrm{N})$, BY T. MOYER AND G.S. MONGANO

$11 / 29 / 93-12 / 07 / 93$ TSINE MEASURED SECTION DATA WERE

$07 / 07 / 94-08 / 04 / 94$ THESE DATA WERE ACQUIRED FROM ANA CORE OSING SCIENTIFIC RLAN SN-0001 STRATIGRAPHIC STODIES FROM GEOLOGIC DESCRIPTION OF CORE, BIT CUTTINGS, AND OOTCROP

ACQN/DEVL, LOCATION : SAMPLE MANAGEMENT FACILITY

**GS940908314211.043 TABLE OF IITHOLOGIC CONTACTS FROM THE BASE OF THE TOPOPAH SPRING TUFF TO TOTAI DEPTH IN BOREHOLE USW OZ-14, VERSION (S) 1. (N), BY T. MOYER AND J. GESLIN. THE CONTACT ALTITUDES FOR THE PROW PASS TUFE SUPERSEDE THOSE FOUND IN THE DATA

SEGMENT PREVIOUSLY IDENTIFIED BY DTN GS940608314211.024. IITHOIOGIC DATA FOR THE THOSE FOOND IN THE DATA SEGMENT PREVIOUSLY IDENTIFIED BY DTN GS940108314211.001. THE CONTACT BETWEEN GS940108314211.001 0 THE CONTACT BETWEEN ONIT 2 AND ONIT 3 OF THE PROW PASS PASS
TOFF IS SOPERSEDED BY THE DATA SEGMENT TOFF IS SOPERSEDED BY THE DATA SEGMEN
IDENTIEIED BY DTN GS950608314211.024.

ACQN/DEVL LOCATION : SAMPLE MANAGEMENT FACIIITY
$04 / 19 / 94-07 / 06 / 94$

\section{$T$}

WERE ACQUIRED FROM ANALYSES OF A $Y T$ CORE USING SCIENTIFIC PLAN SN-0001, DESCRIPTION OF CORE, BIT COTTINGS, AND OOTCROP. 
DATA TRACKING NO.

05/10/94-09/23/94 THESE DATA WERE ACQOIRED FROM ANALYSES OF CORE OSING SCIENTIEIC PLAN SN-0001, STRATIGRAPHIC STUDIES FROM GEOLOGIC DESCRIPTION OF CORE, BIT COTTINGS, AND OOTCROP

PABIE OE IITHOLOGIC CONTACTS FOR THE VARSION(S) 1 (N) BY J. GESIIN AND J. WONDERIICH

ACQN/DEVI IOCATION : SAMPIE MANAGEMENT FACILITY

**GS940908314211.045 GRAPHICAL IITHOLOGIC IOG OF THE PAINTBROSH GROUR FOR BOREHOIE USW SD-12,

$07 / 07 / 94-09 / 23 / 94$ VERSION(S) 1. (N), BY J. GESIIN AND JON R. WONDERITCH

ACQN/DEVI LOCATION : SAMPLE MANAGEMENT FACILITY

* GS941008314211.049 GRAPHICAL IITHOLOGIC LOG FOR BOREHOLE OSW OZ-N32, SURFACE TO TOTAL DEPTH, VERSION(S) 1.(N), BY J. GESIIN. DATA FOR THE RAINTBROSH BEDDED TUEF UNITS TPBT3 AND TPBT4 IN THIS SEGMENT HAVE BEEN SUPERSEDED BY DATA IDENTIFIED BY DTN GS950108314211.008 DATA FOR THE DASE OF TIE BASE OF THE PAH CANYON TOFF TO THE TOP VITROPHYRE HAVE BEEN SUPERSEDED ITROPHYR HAVE BEEN SUPERSEDD BI DATA IDENTIFIED BY DTN GS950108314211.010

ACQN/DEVL LOCATION : SAMPLE MANAGEMENT FACILITY
09/21/94-09/22/94 THESE DATA WERE ACQUIRED FROM ANALYSES OF A Y C CORE USING SCIENTIFIC PLAN SN-0001, STRATIGRAPHIC STODIES FROM GEOLOGIC DESCRIPTION OF CORE, BIT COTTINGS, AND OOTCROP 
SITE CHARACTERIZATION PLAN BASELINE

DATA TRACKING NO.

**GS941008314211.050

TABLE OF LITHOLOGIC CONTACTS IN BOREHOLE OSW SD-9 FROM THE BASE OF THE PAINTBROSH GROUP TO TOTAL DEPTH, VERSION(S) 1.(N), BY T. MOYER (RECORDS PACKAGE INCIODES COMPLETE TABLE OF CONTACTS OF OSW SD-9).

ACQN/DEVI LOCATION : SAMPLE MANAGEMENT FACILITY

$\star \star$ GS941008314211.051 GRAPHICAL IITHOLOGIC IOG FOR BOREHOLE OSW OZ-N31, VERSION (S) 1 . (N), BY J. GESIIN. DATA FOR THE BASE OF THE PAH SPRING TOFF CRYSTAL-RICH VITROPHYRE IN THIS SEGMENT HAVE BEEN SUPERSEDED BY DATA IDENTIFIED BY DTN GS950108314211.010.

ACQN/DEVL LOCATION : SAMPLE MANAGEMENT FACILITY

$\star \star G S 941108314211.052$ GRAPHICAL IITHOLOGIC LOG OF BOREHOLE USW SD -9 FROM THE BASE OF THE PAINTBRUSH GROOP TO TOTAI DEPTH, VERSION (S) 1. (N) , BY T. MOYER AND G.S. MONGANO (RECORDS PACKAGE INCIUDES COMPLETE IOG OF OSW SD-9)

ACQN/DEVL LOCATION : SAMPLE MANAGEMENT FACILITY
ACQN/DEVL PERIOD

ACQN/DEVL METHOD

$09 / 27 / 94-10 / 04 / 94$

THESE DATA WERE ACQUIRED FROM ANALYSES OF

E D

CORE USING SCIENTIFIC PLAN SN-0001,

STRATIGRAPHIC STODIES DESCRIPTION OF CORE, BIT COTTINGS, AND OUTCROP

$10 / 06 / 94-10 / 06 / 94$

THESE DATA WERE ACQUIRED FROM ANALYSES OF

A Y C CORE DSING SCIENTIFIC PLAN SN-0001, STRATIGRAPHIC STODIES FROM GEC DESCRIPTION OF CORE, BIT COTTINGS, AND OUTCROP
$09 / 27 / 94-11 / 02 / 94$$$
\begin{aligned}
& \text { CORE OSING SCIENTIFIC PLAN SN-0001, } \\
& \text { STRATIGRAPHIC STODIES FROM GEOLOGIC }
\end{aligned}
$$
STRATIGRAPHIC STODIES FROM GEOIOGIC DESCRIPTION OF CORE, BIT COTTINGS, AND OUTCROP 


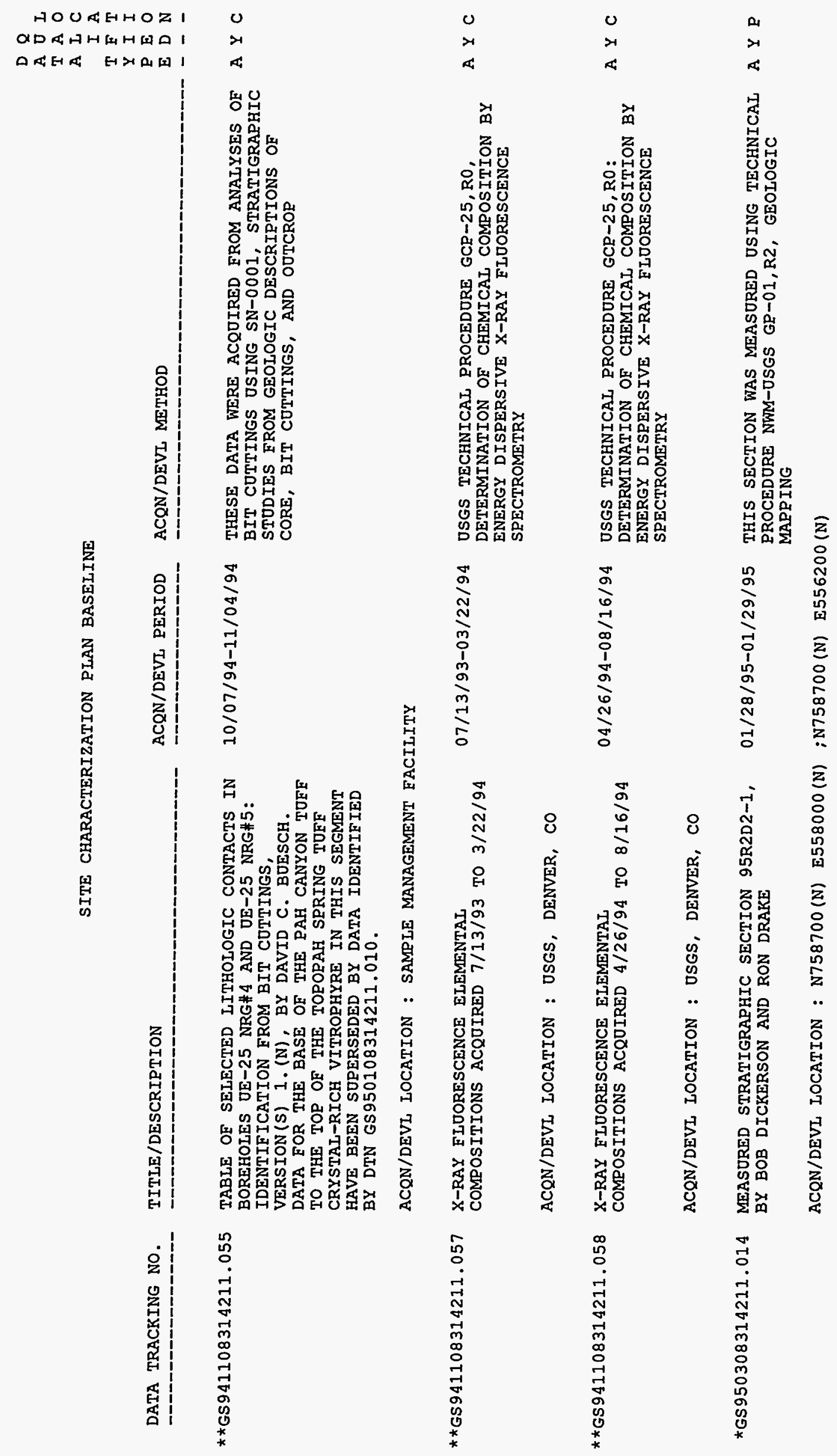


SITE CHARACTERIZATION RLAN BASELINE

DATA TRACKING NO.

TITLE/DESCRIPTION

*GS950308314211.015 ASSESSING THE NATURAI PERFORMANCE OF FELSIC TOFFS USING THE RB-SR AND SM-ND SYSTEMS - - A STODY OF THE ALTERED ZONE IN THE TOPOPAH SPRING MEMBER, PAINTBROSH TUFF, YUCCA MOUNTAIN, NEVADA, BY Z.E. PETERMAN, R.W. SPENGLER, K. FOTA, B.D. MARSHALI AND S. A. MAHAN, THESE DATA SUPERSEDE DATA PREVIOUSLY IDENTIFIED BY DTN'S GS931108315215.032 AND GS910708314211.011.

ACQN/DEVL LOCATION : OSGS, DENVER, CO

*GS950308314211.016 SUMMARY OF DATA FOR LINEAR TRAVERSES: UE-25 NRG\#5 FROM A DEPTH OF 781.5' TO 992.2' AND USW UZ-14 FROM 705' TO $946^{\prime}$ BY JON WONDERLICH

$03 / 30 / 93-09 / 30 / 94$ THIS DATA WAS ACQUIRED USING METHODS DEVELOPED IN SN-0001, STRATIGRAPHIC STODIES FROM GEOLOGIC DESCRIPTION OF CORE, BIT COTTINGS, AND OOTCROP

ACQN/DEVL LOCATION : SAMPLE MANAGEMENT FACILITY, NTS, NV

*GS950408314211.020 MEASURED STRATIGRAPHIC SECTION ON THE EASTERN SIDE OF ABANDONED WASH (SECTION PTN\#10), BY THOMAS MOYER AND JEFFREY GESIIN

$04 / 05 / 95-04 / 05 / 95$

ACQN/DEVI LOCATION : N754150(N) E560500(N)

*GS950508314211.022 SIMPIIFIED STROCTURAL IOG OF BOREHOLE OSW UZ-N35

$01 / 27 / 93-01 / 27 / 93$ THESE DATA WERE ACQUIRED FROM ANALYSES OF CORE OSING SCIENTIFIC NOTEBOOK SN-0001, STRATIGRAPHIC STODIES FROM GEOIOGIC DESCRIPTION OF CORE, BIT CUTTINGS, AND OUTCROP

ACQN/DEVI LOCATION : SAMPLE MANAGEMENT FACILITY, NTS, NV 
DATA TRACKING NO.

TITLE/DESCRIPTION

ACQN/DEVL PERIOD

ACON/DEVI METHOD

$09 / 26 / 94-02 / 09 / 95$

X-RAY ELUORESCENCE ELEMENTAI

COMPOSITIONS ACQUIRED 09/26/94 TO $02 / 9 / 95$

ACQN/DEVL LOCATION : USGS, DENVER, CO

*GS950608314211.024 TABIE OF IITHOLOGIC CONTACTS FROM THE BASE OF THE TOPOPAH SPRING TOFF TO TOTAT DEPTH IN BOREHOLE OSW OZ-14, VERSION(S) 1. (N) , BY T. MOYER AND J. GESIIN THESE DATA SOPERSEDE DATA PREVIOUSLY TO AN ERROR IN REPORTING THE CONTACT BETWEEN UNIT 2 AND ONIT 3 OF THE PROW PASS TOEF.

ACQN/DEVI IOCATION : SAMPIE MANAGEMENT FACILITY

*GS950608314211.025 44 MEASORED SECTIONS, MEASURED IN 1985 AND 1986 IN THE VICINITY OF YOCCA MOUNTAIN

ACON/DEVI LOCATION : N710911(N) E528791(N) N774892(N) E550600 (N) N774892(N) E550600(N) N785207(N) E551912(N) $N 784040(N)$ E5 $51934(N)$ N784040(N) E551934(N) N784980(N) E552110 (N) N784859(N) E552181(N) N786386(N) E553039 (N) N785851 (N) E553118(N) N785453(N) E553231(N) N785886(N) E553799 (N) N784607(N) E554269(N) N783006(N) E555269(N) N783710(N) N782874(N) E55822(N) N735415(N) E5 N781613(N) E5 N778128(N) E561918(N)
06/19/85-03/09/86 DATA WERE COLLECTED USING PROCEDURE GP-01, A N P RO, GEOLOGIC MAPPING.
04/19/94-07/06/94 THESE DATA WERE ACOUIRED FROM ANAIYSES OF A Y P CORE USING SCIENTIFIC PIAN SN-0001. DESCRIPTION OF CORE, BIT CUTTINGS, AND OUTCROP. 
SITE CHARACTERIZATION PLAN BASEIINE

DATA TRACKING NO.

TITLE/DESCRIPTION
ACQN/DEVI PERIOD

ACQN/DEVI METHOD

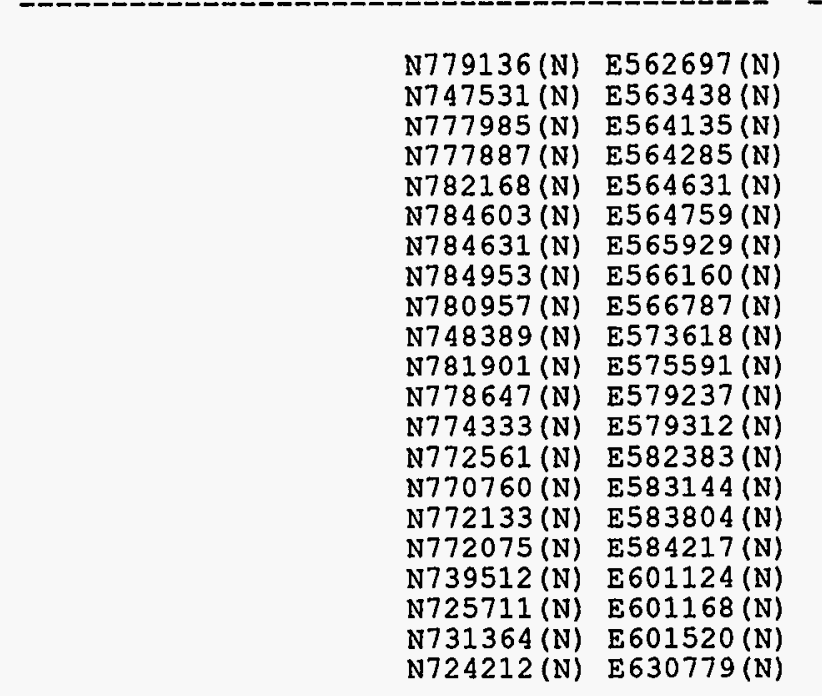

*GS950608314211.026 FRACTURE DATA ACQUIRED FROM TELEVISION LOGS, 1979-1985

ACQN/DEVL LOCATION : OE-25 A\#4

DE -25 B\#1

$\mathrm{UE}-25 \quad \mathrm{C} \# 2$

$\mathrm{UE}-25 \quad \mathrm{OZ} \# 4$

$\mathrm{OE}-25$ OZ\#5

UE-25 WT\#14

UE-25 WTH15

UE-25 WT\#16

$\mathrm{OE}-25$ WTH 17

UE -25 WT\#18

UE-25 WT\#4

UE -25 WT\# 6

USW G-2

USW G-4

USW $\mathrm{H}-3$

$\begin{array}{ll}\text { USW } & H-4 \\ \text { USW } & H-6\end{array}$
$01 / 01 / 79-12 / 31 / 85$

DATA WERE ACOUIRED USING STANDARD OSGS PROCEDORES 
SITE CHARACTERIZATION PLAN BASEIINE

DATA TRACKING NO. TITLE/DESCRIPTION ACQN/DEVI PERIOD

ACON/DEVL METHOD

01/01/90-12/15/90 COMPILATION OF GRAVITY AND AEROMAGNETIC SORVEYS.

USW $0 Z-1$

OSW WT-1

OSW WT-10

OSW WT-11

USW WT-2

USW WT-7

Activity - 8.3.1.4.2.1.2

**GS921108314212.009 GRAVITY AND MAGNETIC ANOMAIIES IN THE VICINITY OF YUCCA MOUNTAIN, NEVADA, AND THEIR GEOLOGIC IMPLICATIONS, BY DAVID A. PONCE AND H.W. OITIVER

ACQN/DEVL LOCATION : USGS, MENLO PARK, CA

**GS930808314212.010 GRAVITY AND MAGNETIC DATA OF MIDWAY VALLEY, SOUTHWEST NEVADA, BY D.A. PONCE V.E. LANGENHEIM, AND R.F. SIKORA

$09 / 30 / 92-08 / 30 / 93$

COMPI DATA

ACQN/DEVL IOCATION : USGS, MENLO PARK, CA

**GS930808314212.011 GRAVITY AND MAGNETIC STUDY OF YOCCA

WASH, SOUTHWEST NEVADA, BY V.E.

LANGENHEIM, D.A. PONCE, H.W. OLIVER, AND

R.F. SIKORA

ACQN/DEVL LOCATION : OSGS, MENLO PARK, CA

**GS940508314212.002

DENSITY AND MAGNETIC SOSCEPTIBILITY

DATA, BARE MOUNTAIN SAMPIES: JANOARY 1 1994 - MARCH 30, 1994 NWM-USGS GPP-11,R2, MAGNETIC METHODS

ACQN/DEVL LOCATION : USGS, MENLO RARK, CA
$01 / 01 / 94-03 / 30 / 94$

NWM-USGS GPP-01,R2, GRAVITY METHODS;

$09 / 30 / 92-08 / 30 / 93$

DATA 
SITE CHARACTERIZATION PLAN BASELINE

DATA TRACKING NO.

TITLE/DESCRIPTION

ACQN/DEVL PERIOD

ACQN/DEVL METHOD

$09 / 27 / 93-10 / 30 / 93$ GHOST DANCE FAOLT GRAVITY AND MAGNETIC DATA, SEPT. 1993, BY H. OIIVER

TECHNICAL PROCEDURES GPP-01, R2, GRAVITY METHODS, AND GRP-11,R2, MAGNETIC METHODS

ACQN/DEVI LOCATION : $3649.82^{\prime} \mathrm{N} 116 \quad 26.56^{\prime} \mathrm{W}$ $\begin{array}{llll}36 & 49.82^{\prime} \mathrm{N} & 116 & 26.59^{\prime} \mathrm{W}\end{array}$ $3649.83^{\prime} \mathrm{N} 11626.62^{\prime} \mathrm{N}$ $36 \quad 49.83^{\prime} \mathrm{N} 11626.68^{\prime} \mathrm{W}$ $\begin{array}{lll}36 & 49.83^{\prime} \mathrm{N} 116 \quad 26.71^{\prime} \mathrm{W}\end{array}$ $\begin{array}{lll}36 & 49.83^{\prime} \mathrm{N} 116 \quad 26.74^{\prime} \mathrm{W}\end{array}$ $\begin{array}{lll}36 & 49.83^{\prime} \mathrm{N} 116 \quad 26.77 \prime \mathrm{W}\end{array}$ $3640.831 \mathrm{~N} 11626.80 \%$ $3649.831 \mathrm{~N} 11626.80 \mathrm{~W}$ $3649.831 \mathrm{~N} 11626.83 \circ \mathrm{W}$ 36 (3) $3649.84 \mathrm{~N} 11626.88 \mathrm{~W}$ $3649.85^{\prime} \mathrm{N} 11626.91^{\prime} \mathrm{W}$ $36 \quad 49.86^{\prime} \mathrm{N} 116 \quad 26.94^{\prime} \mathrm{W}$ $\begin{array}{llll}36 & 49.87^{\prime} \mathrm{N} & 116 & 26.96^{\prime} \mathrm{W}\end{array}$ $\begin{array}{ll}36 & 49.88^{\prime} \mathrm{N} 116 \quad 26.99^{\prime} \mathrm{W}\end{array}$ $\begin{array}{lll}36 & 49.89^{\prime} \mathrm{N} 116 \quad 27.01 ' \mathrm{~W}\end{array}$

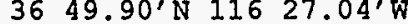
$\begin{array}{lll}36 & 49.90^{\prime} \mathrm{N} 116 \quad 27.07^{\prime} \mathrm{W}\end{array}$ $\begin{array}{lll}36 & 49.90^{\prime} \mathrm{N} 116 \quad 27.10^{\prime} \mathrm{W}\end{array}$ $\begin{array}{lll}36 & 49.91 ' \mathrm{~N} 116 \quad 27.13^{\prime} \mathrm{N}\end{array}$ $36 \quad 49.91 ' N 116 \quad 27.15^{\prime} \mathrm{W}$ $3649.90 \%$ N $116 \quad 27.18 \%$ $3649.89 \% 11627.21 \%$

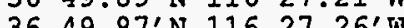
$3649.871 \mathrm{~N} 11627.26 \%$ $3649.87 \% \mathrm{~N} 11627.28 \mathrm{~W}$ $3649.85^{\prime} \mathrm{N} 11627.33^{\prime} \mathrm{W}$

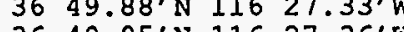
$\begin{array}{lll}36 & 49.85^{\prime} \mathrm{N} 116 & 27.36^{\prime} \mathrm{W}\end{array}$ $3649.84^{\prime} \mathrm{N} 11627.38^{\prime} \mathrm{W}$ 
DATA TRACKING NO.

**GS950108314212.001 MAJOR RESOLTS OF REGIONAI GEOPHYSICAI INVESTIGATIONS AT YUCCA MOUNTAIN AND VICINITY, NEVADA, H.W. OLIVER, D.A. PONCE, AND W.C. HUNTER, EDITORS

ACON/DEVL LOCATION : USGS, MENLO PARK, CA

*GS950608314212.005 MAGNETIC AND GRAVITY DATA FOR THE REGIONAI SIESMIC REFIECTION LINES SITING OF PROPOSED VOLCANIC DRILI' HOLES SITING OF PROPOSED VOICANIC DRILI HOLES IN AMARGOSA VALLEY AND CRATER FLAT, AND CENTRAI BLOCK FROM $11 / 5 / 94$ TO $3 / 31 / 95$

ACQN/DEVL LOCATION : 36 55'00"N $11620^{\prime} 00^{\prime \prime} ; 3627^{\prime} 30^{\prime \prime}$ N $11645^{\prime} 00^{\prime \prime} \mathrm{W}$

*GS950608314212.006 MAGNETIC AND GRAVITY STUDIES OF BURIED

VOLCANIC CENTERS IN THE AMARGOSA DESERT
AND CRATER FIAT, SOUTHWEST NEVADA, BY

VOLCANIC CENTERS IN THE AMARGOSA DESER
AND CRATER ELAT, SOUTHWEST NEVADA, BY V.E. LAANGENHEIM

ACQN/DEVL LOCATION : USGS, MENLO RARK, CA
08/01/87-12/30/94 DESCRIPTION OF INVESTIGATIONS FOCUSING ON GRAVITY, MAGNETIC, MAGNETOTEIIURIC,

SEISMIC REFRACTION, SEISMIC REFLECTION AND TELESEISMIC STODIES. THE GEOLOGIC AND REGIONAL THERMAL SETTINGS AS WELI AS STRESS MEASUREMENTS ARE INCLODED.

11/05/94-03/31/95 DATA WERE ACQDIRED USING TECHNICAI TRE GPP-11, R2-M1, MAGNETIC METHODS
04/01/95-05/31/95 GROUND MAGNETIC AND GRAVITY DATA COLLECTED D Y P OVER THREE AEROMAGNETIC ANOMALIES IN THE VICINITY OF YOCCA MOONTAIN WERE EVAIUATED IN AN EFFORT TO BETTER ONDERSTAND THE HISTORY OF VOLCANISM AND THE PROBABILITY OF FOTORE VOLCANIC ACTIVITY AT YUCCA MOUNTAIN. MODEIING OF DATA WAS USED TO MOUNTAIN. MODELING OF DATA WAS USED TO LOCATE THE EDGES AND ESTIMATE THE MAXIMOM DEPTH TO THE TOP OF THE CAUSATIVE BODY FOR
USE IN DEFINING FUTURE DRILIING LOCATIONS. 
SITE CHARACTERIZATION PLAN BASELINE

DATA TRACKING NO TITIE/DESCRIPTION

Activity $-8.3 \cdot 1 \cdot 4.2 .1 .3$

**GS900908314213.010 INTERPRETATION OF GEOPHYSICAI WELI-LOG MEASUREMENTS IN DRILI HOLES OE 25A-4, -5 $-6,-7(\mathrm{DE}-25 \mathrm{A \# 4}, \mathrm{A \# 5}, \mathrm{A \# 6}, \mathrm{A \# 7)}, \mathrm{Y} O \mathrm{CC}$ MOUNTAIN, NEVADA TEST SITE, BY J.J. DANIELS, J.H. SCOTT, AND J.T. HAGSTROM. DATA FOR THE BASE OF THE PAH CANYON TUFF TO THE TOP OF THE TOPOPAH SPRING TUFF CRYSTAL-RICH VITROPHYRE HAVE BEEN SUPERSEDED BY DATA IDENTIFIED BY DTN SUPERSEDED BY DATA IDENTIFIED BY DTN
GS950108314211.011. DATA FOR THE YOCCA GS950108314211.011. DATA FOR THE YUCCA
MOUNTAIN TUFF IN THIS SEGMENT HAVE BEEN SOPERSEDED BY DATA IDENTIFIED BY DTN GS950208314211.012.

ACQN/DEVI LOCATION : USGS, DENVER, CO Activity - 8.3.1.4.2.2

*RA950000000001.003 ESF NORTH RAMP ELEVATION SORVEY

ACQN/DEVL LOCATION : ESF NORTH RAMP

*RA950000000001.004 ESF NORTH RAMP ELEVATION SURVEY

ACQN/DEVL LOCATION : ESF NORTH RAMP
ACON/DEVI, PERIOD

ACON/DEVL METHOD

06/01/79-12/31/80 STANDARD USGS METHODS.

02/08/95-04/20/95 THE METHOD OF ACQUISITION OF THIS DATA WAS A $Y$ P ACTUAI FIELD SURVEY USING RSN PROCEDORE PP $-01-03$.

04/21/95-06/21/95 THE METHOD OF ACQUISITION OF THIS DATA WAS A Y $P$ ACTUAL FIELD SORVEY USING RSN PROCEDURE PP-01-03. 
Activity $-8.3 .1,4,2.2 .1$

**GS931208314221.012 FAULT ATTITODE DATA OF THE PAINTBROSH CANYON FAOLT SYSTEM.

ACQN/DEVL IOCATION : N770270(N) E570900(N) ;N793000(N) E579000(N)

Activity - 8.3.1.4.2.2.2

$\star * G S 900908314222.001$

FRACTORES IN OOTCROPS IN THE VICINITY OF DRIIL HOLE OSW G-4, YOCCA MOONTAIN NEVADA, DATA ANALYSIS AND COMPILATION BY C.C. BARTON, W.R. PAGE, AND T.I. MORGAN

ACQN/DEVI LOCATION : OSGS, DENVER, CO

**GS940308314222.001 FRACTORE DATA FOR PAVEMENT ARP-1, $12 / 17-22 / 93,2 / 8-12 / 94,2 / 28 / 94$, AND $3 / 1 / 94$

TECHNICAL PROCEDURE NWM-USGS GP-12, R I MAPPING ON PAVEMENTS, OOTCROPS, AND AIONG TRAVERSES

ACQN/DEVL LOCATION : N762,743.93(N) E562,488.87(N)

$$
\text { ARP-1 }
$$

**GS940608314222.002 CHARACTERIZING FRACTURED ROCK FOR

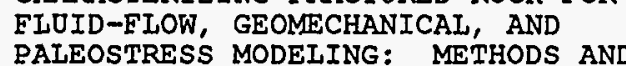
PALEOSTRESS MODELING: METHODS AND PRELIMINARY RESULTS FROM YUCCA MOUNTAIN, NEVADA BY: C.C. BARTON, E. IARSEN, W.R. PAGE, T.M. HOWARD

$01 / 01 / 90-01 / 01 / 91$

CHARACTERIZATION AND MAPPING OF A COMPLEX NETWORK OF FRACTURES WHICH WAS EXPOSED ON THREE 214 TO 260 SQUARE METER PAVEMENTS IN THE OPPER LITHOPHYSAI UNIT OF THE TIVA CANYON MEMBER OF THE MIOCENE RAINTBRUSH TOEF.

ACQN/DEVI LOCATION : USGS, DENVER, CO 
DATA TRACKING NO TITLE/DESCRIPTION

\section{DATA TRACKING NO.}

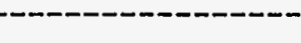

**GS950108314222.001 MAPPING AT FRAN RIDG P2001, BY DONALD S. SWEETKIND

ACQN/DEVI LOCATION : UE-25 P2001

*GS950508314222.003

FRACTORE DATA FROM THREE NATORAT EXPOSORES OF THE PTN SECTION OF SOITTARIO CANYON

ACQN/DEVL LOCATION : N764900(N)

N) $\mathrm{E} 558150(\mathrm{~N})$

*GS950508314222.004

SURFACE FRACTORE NETWORK AT FRAN RIDGE P2001, NEAR YUCCA MOUNTAIN, NYE COUNTY, NEVADA, BY D.S. SWEETKIND, VERBEER, SINGER, BYERS, AND MARTIN

ACQN/DEVL LOCATION : OSGS, DENVER, CO

11/29/94-01/10/95 PAVEMENT WAS MAPPED USING PROCEDORE GP-12, A Y C R1-M1, MAPPING FRACTURES ON PAVEMENTS, OUTCROPS AND AIONG TRAVERSES.

$03 / 20 / 95-04 / 21 / 95$

NATURAL EXPOSURE WAS MAPPED USING GP-12, R1-M1, MAPPING FRACTURES ON PAVEMENTS, OUTCROPS AND AIONG TRAVERSES

:N759530(N) E557450(N)

$02 / 27 / 95-06 / 15 / 95$

THIS REPORT WAS DEVELOPED FROM FIELD OBSERVATIONS AND MEASUREMENTS OF FRACTURE SIZE, ORIENTATION DISTRIBUTIONS, DENSITY AND FRACTURE SYSTEM GEOMETRY SEOUENTIAI DEVELOPMENT OF THE FRACTORE NETWORK AND SUBSEQUENT REACTIVATION OF FRACTURES WERE INTERPRETED IN AN EFFORT TO ONDERSTAND STROCTURAI EVOLOTION, PALEOSTRESS HISTORY STROCTURAI EVOLOTION, PALEOSTRESS HISTORY, AND FRACTURE NETWORK PROPERTIES.

PETROGRAPHIC STUDY OF BRECCIATED FRACTURE FILL INCLUDES A DESCRIPTION OF BRECCIA CIASTS, FRACTORE FIIL CEMENTING MATERIALS, AND ALTERATION MINERALOGY. 
SITE CHARACTERIZATION PLAN BASELINE

DATA TRACKING NO.

TITLE/DESCRIPTION

ACQN/DEVL PERIOD

ACQN/DEVL METHOD

$11 / 21 / 94-03 / 21 / 95$

DATA WERE ACOOIRED OSING TECHNICAI

PROCEDURE NWM-OSGS GP-32, RO, UNDERGROUND GEOLOGIC MAPPING, AND SCIENTIFIC NOTEBOOKS SN-0083, COLLECTION AND PROCESSING OF GEOTECHNICAI DATA, AND SN-0084, COLLECTION OF ONDERGROOND SITE CHARACTERIZATION DATA

ACQN/DEVL LOCATION : EXPLORATORY STODIES FACILITY NORTH RAMP

$11 / 21 / 94-03 / 21 / 95$

DATA WERE DEVELOPED USING TECHNICAT PROCEDORE NWM-USGS GP-32, RO, ONDERGROOND GEOLOGIC MAPPING, AND SCIENTIFIC NOTEBOORS SN-0083, COLLECTION AND PROCESSING OE GEOTECHNICAL DATA, AND SN-0084, COLLECTION OF UNDERGROOND SITE CHARACTERIZATION DATA
*GS950508314224.003 GEOTECHNICAI REPORT FOR STATION $0+60$

TO $4+00$, NORTH RAMP OF THE ESF

ACQN/DEVI IOCATION : NTS
Activity - 8.3.1.4.3.1

**TM000000SD12RP.001 USW SD-12 BOREHOLE SAMPIE COLLECTING AND PROCESSING INEORMATION:

- STRUCTURAL IOGS (YMP-011-R4)

- IITHOLOGIC LOGS (YMP-009-R4)

FROM 300.8 THROUGH 540.7 FEET

ACQN/DEVI LOCATION : N761,956.6(N) ELEV. 4343.0
04/01/94-04/25/94 SAMPLE COILECTING AND PROCESSING ACTIVITIES ARE PERFORMED BY DSQSM IN ACCORDANCE WITH YIP-SII.20-SMF: FIEID IOGGING, HANDIING, AND DOCUMENTING BOREHOLE SAMPIES 
**TM000000SD12RP.002 OSW SD-12 BOREHOLE SAMPLE COLLECTING AND PROCESSING INFORMATION FOR THIS

$04 / 26 / 94-05 / 02 / 94$ RECORDS/DATA SEGMENT IS FROM 540.7 TO 600.7 FEET AND IS RECORDED ON THE FOLLOWING DOCOMENTS: -SHIFT DRILLING SUMMARIES (YMP-012-R2)

-STRUCTURAL IOGS (YMP-011-R4)

STROCTURAL LOGS (YMP-011-R4) ACQN/DEVL LOCATION : $\begin{aligned} \text { N761, } 956.6(\mathrm{~N}) \\ \text { ELEV. } 4343.0^{\prime}\end{aligned}$ (EST) E561,605.7(N) (EST) GROUND

**TM000000SD12RP.003 USW-SD-12 BOREHOLE SAMPLE COLLECTING AND PROCESSING INFORMATION FOR THIS

$05 / 03 / 94-05 / 06 / 94$

660.7 FEET AND IS RECORDED ON THE

FOLLOWING DOCOMENTS: - SHIFT DRIIIING

SOMMARIES (YMP-012-R2) - STROCTORAI

IOGS (YMP-001-R4) - ITTHOIOGTC IOGS

(YMP-009-R4).

ACQN/DEVL LOCATION : N761,956.6(N) (EST) E561,605.7(N) (EST) GROUND ELEV. $4343.0^{\prime}$

**TM000000SD12RP.004 USW SD-12 BOREHOLE SAMPIE COLLECTING AND PROCESSING INFORMATION FOR THIS RECORDS/DATA SEGMENT IS RECORDED ON THE FOLLOWING DOCOMENTS: - SHIFT DRILLING SUMMARIES (YMP-012-R2), 660.7, TO

700.8'; - STROCTORAL LOGS (YMP-001-R4), $667.9^{\prime}$ TO $699.7 \%$. AND - IITHOLOGIC IOG $($ YMP $-009-R 4), 650.0^{\prime}$ TO 675.0'.

ACQN/DEVL LOCATION : N761,956.6(N) (EST) E561,605.7(N) (EST) GROUND ELEV. $4343.0^{\prime}$
$05 / 09 / 94-05 / 13 / 94$

SAMPLE COLLECTING AND PROCESSING ACTIVITIES ARE PERFORMED BY DS\&SM IN ACCORDANCE WITH YLP-SII.2Q-SMF; FIELD LOGGING, HANDIING, AND DOCUMENTING BOREHOLE SAMPLES. ACCORDANCE WITH YIP-SII.20-SMF; FIELD LOGGING, HANDLING, AND DOCUMENTING BOREHOLE SAMPLES. 


\section{DATA TRACKING NO.}

TITLE/DESCRIPTION

ACQN/DEVL PERIOD

ACQN/DEVL METHOD

$05 / 16 / 94-05 / 20 / 94$

USW SD-12 BOREHOLE SAMPLE COLLECTING AND PROCESSING INEORMATION FOR THIS

RECORDS/DATA SEGMENT IS RECORDED ON THE

FOLLOWING DOCUMENTS: - SHIFT DRILIING

SUMMARIES (YMP-012-R2), 700.8-703.9i

STROCTORAI LOGS (IMP-001-R4)

699.5-714.9: AND - IITHOLOGIC IOGS

(YMP-009-R4)，675.0 TO 725.0

ACQN/DEVI LOCATION : N761,956.6(N) (EST) E561,605.7(N) (EST) GROOND

ELEV. $4343.0^{\circ}$

Activity $-8 \cdot 3 \cdot 1 \cdot 4 \cdot 3 \cdot 1.1$

**SNT02012894001.001 GEOIOGIC CORE LOGS FOR OSW SD-12

$05 / 27 / 94-10 / 19 / 94$

GEOLOGIC LOGGING OF DRIII CORE AND

ASSOCIATED VIDEO TAPES; HAND SPECIMEN EXAMINATION UNDER HAND IENS OR BINOCULAR MICROSCORE.

ACQN/DEVI LOCATION : YMP SAMPLE MANAGEMENT FACILITY

$\star \star$ SNT02052794001.001 GEOIOGIC CORE IOGS FOR USW SD-9. (THIS DATA HAS BEEN SOPERSEDED BY DTN:

$05 / 27 / 94-10 / 19 / 94$ DATA HAS BEEN SUPER

ACQN/DEVI LOCATION : YMP SAMPLE MANAGEMENT FACIIITY

*SNT02052794001.002 GEOIOGIC CORE IOGS FOR USW SD-9. (THIS DATA SUPERSEDES DATA PREVIOUSLY

$05 / 27 / 94-04 / 04 / 95$ IDENTIFIED BY DTN: SNT02052794001.001)

ACQN/DEVI LOCATION : YMP SAMPLE MANAGEMENT FACILITY
SAMPIE COLLECTING AND PROCESSING LOGGING, HANDIING, AND DOCOMENTING BOREHOLE SAMPIES. ACTIVITIES ARE PERFORMED BY DS\&SM IN
GEOLOGIC LOGGING OF DRILL CORE AND ASSOCIATED VIDEO TAPES; HAND SPECIMEN EXAMINATION ONDER HAND LENS OR BINOCOLAR MICROSCOPE. 
SITE CHARACTERIZATION PLAN BASELINE

DATA TRACKING No.

TITLE/DESCRIPTION

*SNT02110894001.001 GEOLOGIC CORE LOGS FOR USW SD-7

ACQN/DEVL LOCATION : YMP SAMPLE MANAGEMENT FACILITY

Activity - 8.3.1.5.1.1.1

*GS950608315111.001 DELTA-D AND DELTA-180 VALUES OF PRECIPITATION AT YUCCA MOUNTAIN AND

SORROUNDING REGIONS ON SAMPIES COLLECTED

FROM $2 / 93$ TO $2 / 95$

ACQN/DEVL LOCATION : USGS, DENVER, CO

Activity - 8.3.1.5.1.4.2

**GS940108315142.003 FIELD NOTES AND STATION LOCATION MAP SOPPORTING SURFICIAI GEOLOGIC MAPRING OF THE NORTHEAST $1 / 4$ OF THE BUSTED BUTTE

$05 / 01 / 92-12 / 22 / 93$

GEOLOGIC MAPPING FOLLOWING TECHNICAI PROCEDURE GP-01,R2, GEOLOGIC MAPPING, INCLODING AIRPHOTO INTERPRETATION AND FIELD OBSERVATIONS.

ACQN/DEVI LOCATION : $3648^{\prime} 45^{\prime \prime N} 116 \quad 26^{\prime} 15^{\prime \prime} \mathrm{W} ; 36 \quad 52^{\prime} 30^{\prime \prime} \mathrm{N} 116 \quad 22^{\prime} 30^{\prime \prime} \mathrm{W}$

**GS940108315142.004 PRELIMINARY SURFICIAL DEPOSITS MAP OF THE NORTHEAST QUARTER OF THE BUSTED BOTTE 7.5-MINOTE QUADRANGLE, BY S.C. IONDSTROM, J.R. WESIING AND E.M. TAYIOR $(1: 12,000)$

$05 / 01 / 92-12 / 22 / 92$

COMPILATION AND ANALYSIS OF SURFICIAI DEPOSIT MAPPING DATA INCIUDING ATRPHOTO INTERPRETATION AND FIELD OBSERVATIONS, AND AGE DATA FROM THERMOIUMINESCENSE AND U-SERIES ANALYSES OF SAMPLES.

ACQN/DEVI LOCATION : USGS, LAS VEGAS, NV 
DATA TRACKING NO.

TITLE/DESCRIPTION

ACQN/DEVL PERIOD

ACON/DEVT, METHOD

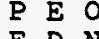

**GS940108315142.005 PREIIMINARY SURFICIAL DEPOSITS MAP OF THE SOOTHERN HALF OF THE TOPOPAH SPRING NW 7.5-MINOTE QDADRANGLE, BY S.C. IONDSTROM AND E.M. TAYIOR $(1: 12,000)$

ACQN/DEVL IOCATION : OSGS, LAS VEGAS, NV

**GS940708315142.008 PREIIMINARY SUREICIAI DEPOSITS MAP OF THE NORTHWEST OUARTER OF THE BOSTED BOTTE 7.5-MINOTE ODADRANGLE, NYE COUNTY, NEVADA, BY S.C. IUNDSTROM, S.A. MAHAN, AND J.B. PACES $(1: 12,000)$

ACQN/DEVL LOCATION : USGS, LAS VEGAS, NV

*GS950408315142.004 PREIIMINARY MAP OF THE SORFICIA DEPOSITS OF THE SODTHERN HAIF OF THE BOSTED BOTTE 7.5, QOADRANGLE, NYE COONTY, NEVADA, BY SCOTT LUNDSTROM, J. WHITNEY, J. PACES, AND S. MAHAN.

ACQN/DEVI IOCATION : OSGS, LAS VEGAS, NV

*GS950408315142.005 FIELD NOTES AND STATION LOCATION MAP SUPPORTING SURFICIAI DEPOSITS MAPPING OF THE SOOTHERN HALF OF THE TOPOPAH SPRING NW QUADRANGLE

ACQN/DEVI LOCATION : $3652^{\prime} 30^{\prime \prime} \mathrm{N} 11630^{\prime} \mathrm{O}^{\prime \prime} \mathrm{W} ; 3656^{\prime} 15^{\prime \prime} \mathrm{N} 11622^{\prime} 30^{\prime \prime} \mathrm{W}$
$05 / 01 / 92-12 / 22 / 93$

COMPILATION AND ANALYSIS OF SURFICIAI DEPOSIT MAPPING DATA, INCLODING AIRPHOTO INTERPRETATION AND FIEID OBSERVATIONS, AND AGE DATA FROM THERMOLUMINESCENSE AND O-SERIES ANAIYSES OF SAMPLES.

$04 / 04 / 94-07 / 27 / 94$ THE MAP WAS COMPILED FROM A COMBINATION OF $D Y$ AIRPHOTO INTERPRETATION AND FIELD CHECKS AS DOCUMENTED IN FIEID NOTEBOOKS, AS WELI AS AGE DATA OBTAINED FROM THERMOLOMINESCENSE AND O-SERIES ANALYSES OF SAMPLES.

10/01/94-01/25/95 THE MAP WAS COMPILED FROM A COMBINATION OF D $Y$ P AIRPHOTO INTERPRETATION AND FIELD CHECKS AS DOCOMENTED IN FIEID NOTEBOOKS AND AGE DATA OBTAINED FROM THERMOLUMINESCENCE AND O-SERIES ANALYSES OF SAMPLES.

05/01/92-06/30/93 GP-01, R2, GEOLOGIC MAPPING. 
Activity - 8.3.1.5.2.1.3

$\star \star G S 910508315213.001$ PHYSICAL PROPERTY DATA FROM PLAYA SOII SAMPLES COLLECTED $1 / 4 / 91$ TO $1 / 10 / 91$ AT JORNADA, FLAT, OLD COE, DRY (ON FT. BLISS RANGE), ISAACK, PLAYAS AND GRONTON IAKES, AND WHITE SANDS IN NM

BROADWELL, DANBY, DRY (NEAR PANAMINT SPRING) DRY (ON 29 PAIMS BASE) FORD DRY, FORD, HARPER, HAYFIELD, AND MIRROR IAKES, AND BADWATER IN CA; PETERS PLAYA IAKES, AND BADWATER IN CA; PETERS PLAY AND STEWART VALLEY IN NV; $1 / 24 / 91$ TO $1 / 26 / 91$ AT ELDORADO DRY, JEAN, AND ROACH
DRY LAKES IN NV, AND IVANPAH DRY, SILVER DRY, SODA, EAST CRONESE, AND LUCERNE LAKES IN CA; AND 3/24/91 AT SILURIAN DRY IAKE, CA

ACON/DEVL LOCATION : $3246^{\prime} 31^{\prime \prime N} 10608^{\prime} 39^{\prime \prime} \mathrm{W}$ $32471^{\prime} 51 " \mathrm{~N} 10612^{\prime} 27^{\prime \prime N}$ 32 47'50"N 106 12, $45 " \mathrm{~W}$ 32 14.08"W 106 23, 05 "W $3214.08 " \mathrm{~N} 1063^{\prime} 03^{\prime \prime W}$ $321^{\prime} 08^{\prime \prime N} 1063^{\prime} 07$ "W 32 0 $317^{\prime \prime} \mathrm{N} 10631^{\prime} 10 " \mathrm{~W}$ 32 07'11"N $10631^{\prime} 14^{\prime \prime} \mathrm{W}$ $32 \quad 27^{\prime} 22^{\prime \prime N} 106 \quad 43^{\prime} 07 " \mathrm{~W}$ $32 \quad 27^{\prime} 22 " \mathrm{~N} 106 \quad 43^{\prime} 13^{\prime \prime} \mathrm{W}$ $3245^{\prime} 32 " \mathrm{~N} 10654^{\prime} 00 " \mathrm{~W}$ $3245^{\prime} 27 " \mathrm{~N} 10654^{\prime} 15^{\prime \prime} \mathrm{W}$ 33 05'37"N $10700^{\prime} 45^{\prime \prime} \mathrm{W}$ $33 \quad 05^{\prime} 40^{\prime \prime N} 107 \quad 02^{\prime} 00^{\prime \prime} \mathrm{W}$ $3153^{\prime} 58^{\prime \prime N} 108 \quad 12^{\prime} 30 " \mathrm{~W}$ $3154^{\prime} 00^{\prime \prime N} 10812^{\prime} 34^{\prime \prime} \mathrm{W}$ $3154^{\prime} 34^{\prime \prime N} 1085^{\prime} 46^{\prime \prime W}$ $3154^{\prime} 33$ "N $10835,58^{\prime \prime W}$ 31 52,03"N $11456^{\prime \prime} 33^{\prime \prime}$ 35 (52,03"N $11456^{\prime} 33^{\prime \prime} \mathrm{W}$ $3336^{\prime \prime} 56^{\prime N} 11458^{\circ} 43^{\prime \prime W}$ 33 37'51"N 11501,43 "W $3328,48 " N 115$ N $32,27 " W$ $3338^{\prime} 38^{\prime \prime N} 115$ N $32^{\prime} 32^{\prime \prime W}$ $3411.15^{\prime \prime N} 11502^{\prime} 39^{\prime \prime} \mathrm{W}$ $3547^{\prime} 30^{\prime \prime} \mathrm{N} 11515^{\prime} 40^{\prime \prime} \mathrm{W}$ $3539^{\prime} 47 " \mathrm{~N} 11521,53^{\prime \prime} \mathrm{W}$
01/04/91-01/10/91 $01 / 24 / 91-01 / 26 / 91$ $03 / 24 / 91-03 / 24 / 91$

SAMPLES WERE COLLECTED WITH A BED

R AND PHYSTCAI DESCRIBED OSING GP-17, RI, "DESCRIBING AND SAMPIING SOILS IN THE FIEID". 


\section{DATA TRACKING}

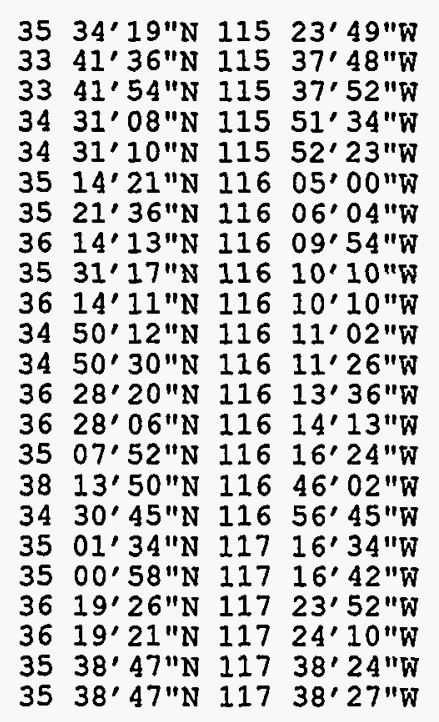

**GS911108315213.004 LAB ANALYSIS RESULTS AND PHYSICAI PROPERTY CHARACTERISTICS FROM PLAYA SOIL SAMPIES TAKEN FROM VARIOUS PLAYAS IN CALIFORNIA AND NEVADA, 10/17/91 TO 10/26/91. NEVADA LOCATIONS: BIG SMOKEY VALLEY, BONNIE CLAIR, COAI VALLEY, STEWART VAIIEY, PAHROMP VALIEY, PETER'S AND IIDA JUNCTION SODTH PIAYAS; ALKAII FLAT, FRENCHY LAKE, MOD LAKE, AMARGOSA FLAT, RALSTON VALLEY, SAND SPRING, SARCOBATOS FLAT, SO. RAII ROAD
VALIEY AND STONE CABIN VAILEY. CAIIFORNIA LOCATIONS: EAST CRONESE, LUCERNE, SILURIAN, SILVER AND SODA LAKES, COTTONBALI BASIN AND MESQOITE FLAT.

$10 / 17 / 91-10 / 26 / 91$ $07 / 08 / 92-07 / 28 / 92$

ACQN/DEVL LOCATION : $3732^{\prime} 15^{\prime \prime N} 11513^{\prime} 18^{\prime \prime}$ $3732^{\prime} 15^{\prime \prime N} \quad 115 \quad 13^{\prime} 18^{\prime \prime} \mathrm{W}$
SAMPLES COILECTED AND PHYSICAI PROPERTIES DESCRIBED OSING GP-17,R1, "DESCRIBING AND SAMPIING SOILS IN THE FIELD". ANALYSIS BY DSGS GEOLOGIC DIVISION, BRANCH OF GEOCHEMISTRY, (APEROVED VENDOR) LAB PROCEDURES. 
SITE CHARACTERIZATION PLAN BASEIINE

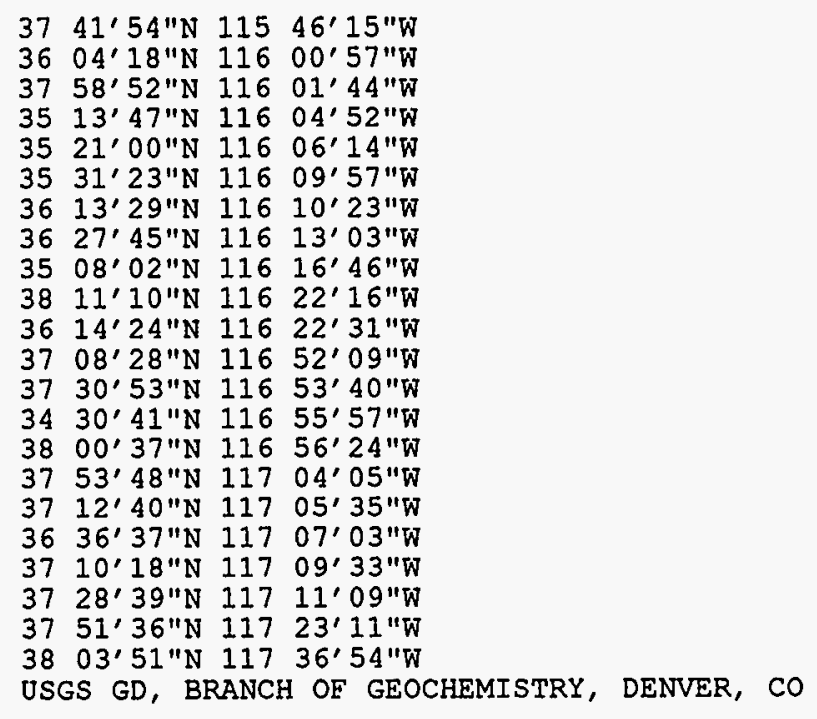

**GS911208315213.005 LAB ANALYSIS RESULTS AND PHYSICAL

PROPERTY CHARACTERISTICS OF SURFICIAI

SOIL SAMPIES TAKEN FROI

PLAYA, AZ, AND SOUTH ALKALI FLAT, NM,

$11 / 12 / 91-11 / 14 / 91$

$12 / 01 / 91-01 / 01 / 92$

$11 / 12 / 91-11 / 14 / 91$.

ACQN/DEVL LOCATION : $\begin{array}{rlll}32 & 16^{\prime} 24^{\prime N} 10854^{\prime} 26^{\prime \prime} \mathrm{W} \\ 32 & 09^{\prime} 09^{\prime N} 10954^{\prime} 03^{\prime \prime} \mathrm{W}\end{array}$

OSGS GD, BRANCH OF GEOCHEMISTRY, DENVER, CO
SAMPLES COLLECTED FROM THE SURFACE TO 5CM A Y T AND PHYSICAI PROPERTIES DESCRIBED USING GP-17, R1, "DESCRIBING AND SAMPLING SOIIS IN THE FIELD". ANALYSIS BY USGS GEOLOGIC DIVISION, BRANCH OF GEOCHEMISTRY,

(APPROVED VENDOR) LAB PROCEDURES. 
DATA TRACKING NO.

TITLE/DESCRIPTION

ACQN/DEVI PERIOD

ACQN/DEVI METHOD

12/01/91-08/30/92 DSE OF DISTRIBOTED PARAMETER RONOFE SIMOLATION MODEL AND MODIFICATION OF A FIELD-SCAIE MODEI FOR INTERCHANNEI, RONOFE AND RECHARGE.

\section{$04 / 08 / 90-04 / 24 / 90$} HP-173, RO, DATA COLLECTION PROTOCOL FOR PLANT COMMONITY ANALYSIS, OSED TO COLLECT RAW VEGETATION DATA MEASUREMENTS.
VEGETATION TRANSECT DATA FOR AMARGOSA

VALIEY INCLODING VEGETATION SPECIES

NAMES, COVERAGES, LENGTH, HEIGHT AND

EMERICK AND OTHERS.

ACON/DEVL LOCATION : $3647^{\prime} 25^{\prime \prime N} 11617^{\prime} 31 " \mathrm{~W}$

36 25' $27^{\prime \prime N} 11618^{\prime} 01 " \mathrm{~W}$

$3625,25 " \mathrm{~N} 116,18,02 \mathrm{NH}$

$3637,47 " \mathrm{~N} 11618,02 " \mathrm{~W}$

36 38.04"N $11618^{\circ} 06^{\prime \prime W}$

36 38'04'N 116 18, $11 " \mathrm{~W}$

$3624^{\prime} 36^{\prime \prime N} 11618^{\prime} 15^{\prime \prime W}$

362437 N $11618^{\prime} 21 " \mathrm{~W}$

$3636^{\prime} 30^{\prime \prime N} 11618^{\prime} 37^{\prime \prime W}$

$3646^{\prime} 37 " \mathrm{~N} 116$ 19'04"W

3637 '41"N 11619 '27"W

$3614^{\prime} 35^{\prime \prime N} 11620^{\prime} 20^{\prime \prime} \mathrm{W}$

$3638^{\prime} 11 " \mathrm{~N} 11620^{\prime} 36^{\prime \prime} \mathrm{W}$

$3646^{\prime} 04^{\prime \prime N} 11620^{\prime} 38^{\prime \prime W}$

$3614^{\prime} 35^{\prime \prime N} 11620^{\prime} 40^{\prime \prime} \mathrm{W}$

$3649^{\prime} 07^{\prime \prime N} 11621^{\prime} 36^{\prime \prime} \mathrm{W}$

$3628^{\prime} 42^{\prime \prime N} 11621^{\prime} 41^{\prime \prime} \mathrm{W}$

$362^{\prime} 28^{\prime}$ "N $11621{ }^{\prime} 55^{\prime \prime}$

$3614^{\prime} 25^{\prime \prime N} 11622^{\prime} 05^{\prime \prime} \mathrm{W}$

36 14, 55"N 11622,25 "W

36 28,03"N $11622,31 " \mathrm{~W}$

3638,15 N 116 22, 31 W

36 38, 15 'N $11622^{\prime} 31^{\prime \prime W}$

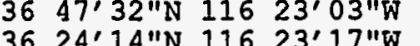

36 24.14'N 116 23.17"W

$3645^{\prime} 19^{\prime \prime N} 11623^{\prime} 28^{\prime \prime W}$

$366^{\prime} 16^{\prime \prime N} 11623^{\prime} 38^{\prime \prime} \mathrm{W}$

$3645^{\prime} 14^{\prime \prime N} 11623$, 40 "W 
SITE CHARACTERIZATION PLAN BASELINE
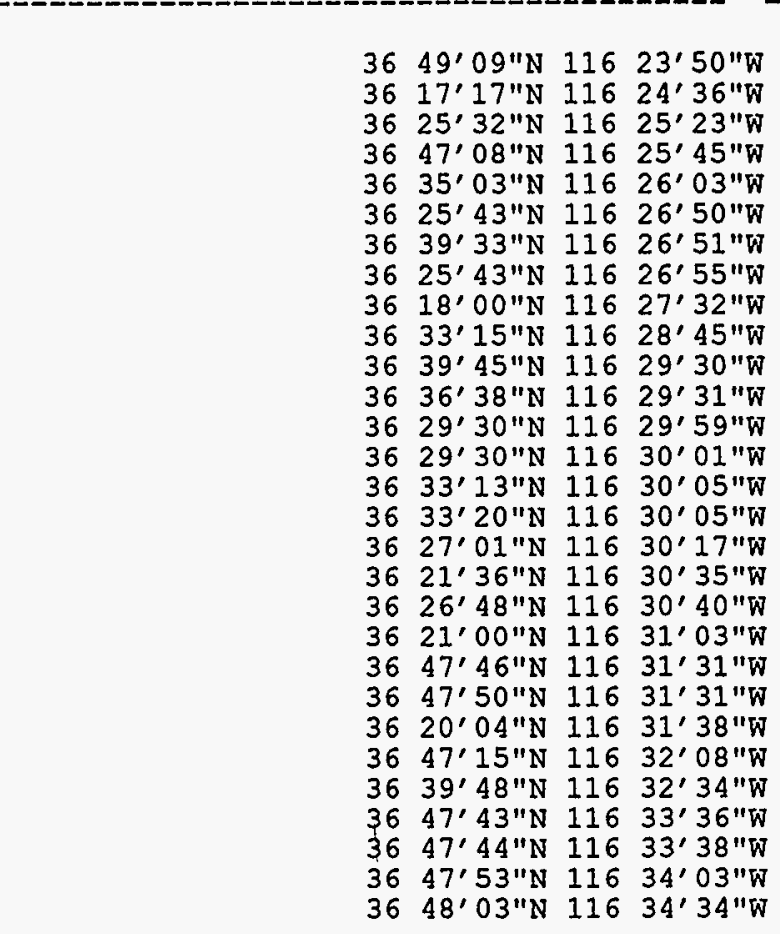

**GS930308315213.013 PHYSICAL SOIL PROPERTY DATA AND SOIL CHEMISTRIES OF SAMPLES FROM RED LAKE, AZ, JEAN LAKE AND ROACH IUAKE, NV, AND MESQUITE LAKE, CA, 3/21/92-3/24/92.

ACQN/DEVI LOCATION : $3540^{\prime} 00^{\prime \prime N} 11407^{\prime} 30^{\prime \prime} \mathrm{W}$ $3547^{\prime} 18^{\prime \prime} \mathrm{N} 11515^{\prime} 00^{\prime \prime} \mathrm{W}$ $3547^{\prime} 00^{\prime \prime N} 11515^{\prime} 33^{\prime \prime} \mathrm{W}$ $3539^{\prime} 42 " \mathrm{~N} 11521^{\prime} 18 \mathrm{~W}$ $3539^{\prime} 42^{\prime \prime N} 11522^{\prime} 06^{\prime \prime} \mathrm{W}$ $3543^{\prime} 12^{\prime \prime} \mathrm{N} 11534^{\prime} 48^{\prime \prime} \mathrm{W}$
$03 / 21 / 92-03 / 24 / 92$ $05 / 07 / 92-06 / 23 / 92$

SAMPLES COLLECTED AND DESCRIBED USING

GP-17, R1, "DESCRIBING AND SAMPLING SOILS

IELD" IAB ANALYSIS BY APPROVED VENDOR: STANDARD USGS BRANCH OF

GEOCHEMISTRY LAB PROCEDORES AND METHODS. 
$3542^{\prime} 15^{\prime \prime N} 11534^{\prime} 52^{\prime \prime} \mathrm{W}$

$3542^{\prime} 42^{\prime \prime N} 11534^{\prime} 54^{\prime \prime} \mathrm{W}$

USGS GD BRANCH OF GEOCHEMISTRY, DENVER, CO

**GS940908315213.002 U-TH ISOTOPIC DATA AND O-SERIES DISEQOILIBRIUM DATING OF SPRING DISCHARGE DEPOSITS NEAR THE SOOTHERN END OF CRATER FIAT. DATA INCLODE SAMPIE PREPARATION DESCRIPTIONS, ALPHA SPECTROMETRIC RESULTS, MASS SPECTROMETRIC RESULTS, A SUMMARY OF SPECTROMERTC RESOLTS, A SOMMARY OF RATIOS, ERRORS AND ERROR CORRELATIONS OF THE ISOTOPES OF INTEREST $(2380,2360$, THE ISOTOPES OF INTEREST (2380, 2360, $2340,232 \mathrm{TH}, 230 \mathrm{TH}, 229 \mathrm{TH})$, AND RESULTS
OE REGRESSION ANALYSIS TO OBTAIN $230 \mathrm{TH} / 0$ AGES.

ACQN/DEVL LOCATION : USGS D-SERIES LABS, DENVER, CO

**GS941208315213.010 PHYSICAI SOIL PROPERTY DATA FROM PLAYA SAMPLES COLLECTED ON 5/21/91 AT FRANKLIN ILAKE PLAYA

ACQN/DEVL LOCATION : 36 14'00"N 116 22'30"W

**GS941208315213.011 PHYSICAI AND GEOCHEMICAI SOII PROPERTY DATA FROM PLAYA SAMPLES COLLECTED AT SOOTH THREE LAKES, DOG BONE LAAKE, NORTH DOG BONE IAKE, CENTRAI THREE ILAKES INDIAN SRRINGS, NORTH INDIAN SPRINGS AND DESERT DRY ILAKE IN NEVADA, 4/24/93 4/25/93, AND SAMPIES COLIECTED AT BROWNS LAKE, ANTEIOPE IAKE, GOLD FIAT, STONEWAII FLATS, KAWICH AND TICABOO PLAYAS IN NEVADA $6 / 2 / 93-6 / 5 / 93$

ACON/DEVI LOCATION : $3658^{\prime} 08^{\prime \prime N} 11513^{\prime} 21 " \mathrm{~W}$ $364^{4} 49^{\prime} 47^{\prime \prime N} 11526^{\prime} 48^{\prime \prime} \mathrm{W}$

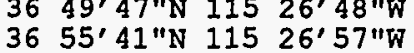

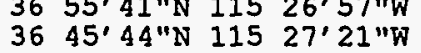

$05 / 21 / 91-05 / 21 / 91$

11/01/92-09/08/94

YMP-OSGS GCP-03,R2, O-SERIES DATING AND GCP-03,R3， ORANIUM-THORIUM DISEQOILIBRIOM STODIES

$04 / 24 / 93-04 / 25 / 93$ $06 / 02 / 93-06 / 05 / 93$ $08 / 17 / 93-09 / 10 / 93$

CLECTED AND DESCRIBED OSINC GAMPLES COLLECTED AND DESCRIBED USING IN THE FIELD". ANALYSIS BY APPROVED VENDOR.
SAMPLES COLIECTED AND DESCRIBED USING GP-17, R1, "DESCRIBING AND SAMPIING SOILS IN THE FIELD". 
SITE CHARACTERIZATION PLAN BASEIINE

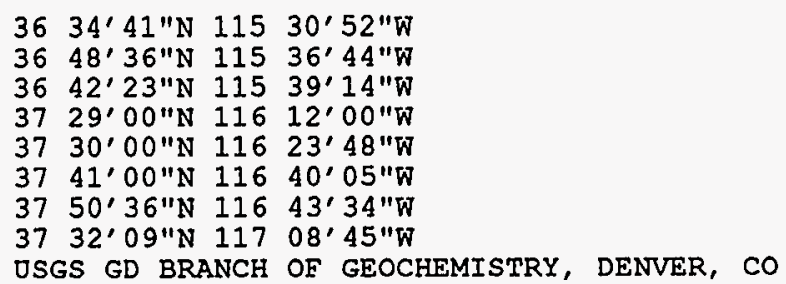

*GS950408315213.002 PHYSICAL PROPERTY DATA FROM WATER SAMPLES COLLECTED AT CACTOS SPRING, NV, KING SPRINGS, NV, ROSE'S WELI, NV, CA, AND TRIANGLE SPRING, CA, 11/92 TO 6/93 - SAMPIES COLLECTED ACCORDING TO SN-0006

ACQN/DEVI LOCATION : $3744^{\prime} 22^{\prime \prime N} 11620^{\prime} 12^{\prime \prime} \mathrm{W}$ $3624^{\prime} 21 " \mathrm{~N} 11622^{\prime} 40^{\prime \prime} \mathrm{W}$ $3540^{\prime} 53^{\prime \prime N} 11625^{\prime} 17^{\prime \prime} \mathrm{W}$ $3743^{\prime} 16^{\prime \prime N} 11649^{\prime} \quad 03^{\prime \prime} \mathrm{W}$ $36 \quad 43^{\prime} \quad 07 " \mathrm{~N} 117 \quad 07$ ' $30 " \mathrm{~W}$

*GS950508315213.003 RADIOCARBON AGE DETERMINATION BY ACCEITRATOR MASS SPECTROMRTRY ON CARBONATE IN THE FORM OF SNAIL SHELIS AND RHIZOLITHS

$11 / 10 / 94-03 / 15 / 95$

RADIOCARBON DATING BY ACCELERATOR MASS SPECTROMETRY PERFORMED BY BETA ANAIYTICAI, A OSGS APPROVED VENDOR, ONDER PURCHASE ORDER $1434 \mathrm{CR}-95-\mathrm{SA}-0752$
SN-0006, "COLIECTION OF BENTHIC AOOATIC MICRO-ORGANTSMS TARGER THAN 150 MICROMETERS $(0.0059$ INCHES $)$.

ACQN/DEVL LOCATION : BETA ANALYTICAL INC., MIAMI, FL 
DATA TRACKING NO.

TITLE/DESCRIPTION

ACQN/DEVL PERIOD

ACQN/DEVI METHOD

P E

E D N

*GS950608315213.004 URANIUM AND THORIUM ISOTORE DATA DETERMINED BY MASS SPECTROMETRY FOR PALEODISCHARGE DEPOSITS ANALYZED IN FY95: DATA INCLODE SAMPLE AND SPIKE WEIGHTS, MEASORED ORANIOM AND THORIOM AND THORIOM ISOTOPIC RATIOS, AND PERTINENT INFORMATION OSED TO CALCOLATE ORANIOM-SERIES DISEQOILIBRIOM PARAMETERS INCIODING AGES AND PROPOGATED

ONCERTAINTIES.

ACQN/DEVI LOCATION : DSGS, DENVER, CO

Activity - 8.3.1.5.2.1.4

**GS931008315214.032 METEOROLOGICAL, STREAM-DISCHARGE, AND WATER-QOALITY DATA FOR WATER YEAR 1992 FROM TWO BASINS IN CENTRAI NEVADA, BY P.W. MCKINLEY AND THOMAS OLIVER

ACQN/DEVI LOCATION : OSGS, DENVER, CO
10/01/94-05/01/95 YMP-DSGS GCP-03,R3 DRANIOM-THORIOM DISEQUILIBRIOM STUDIES
12/01/92-10/08/93 DATA WERE DEVELOPED INTO DAILY VALUE

TABLES DSING THE NATIONAI WATER

INEORMATION SYSTEM (NWIS) DATABASE.

MISSING DATA WERE ESTIMATED BY REGRESSION

TO OTHER METEOROLOGICAL DATA OSING MINITAB

RELEASE 7.2 OR WERE ESTIMATED BY

INTERPOLATION. 
SITE CHARACTERIZATION PLAN BASELINE

DATA TRACKING NO.

TITLE/DESCRIPTION

Activity - 8.3.1.5.2.1.5

**GS911008315215.013 87SR/86SR ANALYSIS OF BAILED WATER SAMPLE FROM DRILI HOLE OE25P\#1, YOCCA MOONTAIN NEVADA.

ACQN/DEVL LOCATION : UE25P\#1

**GS911008315215.014 ANALYTICAL RESULTS OF URANIUM AND URANIUM ACTIVITY RATIOS IN WELDED TOEE URANIUM ACTIVITY RATIOS IN WELDED

ACQN/DEVL LOCATION : FRENCHMAN FLAT JACKASS ELATT

**GS920708315215.024 URANIUM CONCENTRATIONS, ISOTOPIC ACTIVITY RATIOS, AND AGES OF CARBONATE DEPOSITS

ACQN/DEVL LOCATION : USGS, DENVER, CO

**GS920708315215.025 URANIUM CONCENTRATIONS, ISOTOPIC ACTIVITY RATIOS, AND AGES OF CARBONATE DEPOSITS AND YUCCA MOUNTAIN AREA GROUND WATER

ACQN/DEVL LOCATION : USGS, DENVER, CO
ACON/DEVL PERIOD

ACON/DEVL METHOD

$\begin{array}{llll}D & Q & \\ \text { A } & 0 & I\end{array}$

T'A

A I C

I $A$

$T F T$

$Y$ I I

P E O

E D N

06/12/90-06/19/90 NWM-OSGS-GCP-12, RB-SR ISOTOPE

A Y C

A N C

02/13/89-02/13/89 NWM-OSGS-GCP-03

$07 / 03 / 86-07 / 15 / 86$

METHODS DESCRIBED IN GCP-03,RO \& R1 ORANIOM-SERIES DATING，\& GCP-04,RO \& R1 ORANIUM-TREND DATING.

$06 / 22 / 89-04 / 10 / 92$

METHODS DESCRIBED IN GCP-03,R1 ORANIUM-SERIES DATING，GCP-04,R1

A $\mathrm{Y} \mathrm{C}$ ORANITM-TREND DATING. 
DATA TRACKING NO.

TITLE/DESCRIPTION

ACQN/DEVL PERIOD

ACQN/DEVI METHOD

$11 / 01 / 89-12 / 31 / 89$

RECONNAISSANCE CARBONATE CARBON AND OXYGEN ISOTOPE DATA FROM TRENCH 14 BUSTED BUTTE, AND DRILL HOLE (OSW) G-4 YOCCA MOONTAIN, NEVADA, TEST SITE, BY J. WHELAN AND J.S. STUCKLESS

ACQN/DEVL LOCATION : USGS, DENVER, CO

**GS931108315215.033 FIOID INCLOSION TEMPERATORES FROM DRILI HOLES USW G-1 AND G-2, OCT. 92 - SEPT. 93.

$10 / 01 / 92-09 / 30 / 93$

ACQN/DEVI LOCATION : HARVARD ONIV., CAMBRIDGE, MA

**GS940108315215.002 FLUID INCLOSION STUDIES OF CAICITE VEINS FROM YOCCA MOUNTAIN, NEVADA, TOFFS: ENVIRONMENT OF FORMATION, BY E. ROEDDER

$08 / 24 / 93-12 / 30 / 93$ J.F. WHELAN, AND D.T. VANIMAN.

ACQN/DEVL LOCATION : HARVARD ONIV., CAMBRIDGE, MA

**GS941108315215.010 STRONTIOM ISOTOPE RATIOS AND ISOTOPE DILOTION DATA FOR ROBIDIUM AND STRONTIUM COLIECTED $12 / 6 / 93$ TO $8 / 17 / 94$

$12 / 06 / 93-08 / 17 / 94$

ACQN/DEVL LOCATION : OSGS, DENVER, CO
ANAIYSIS OF CARBONATE CARBON AND OXYGEN ISOTORE VALUES OF CAICITE EROM THE YUCCA MOONTAIN AREA TO DETERMINE TRENDS AND VARIATIONS ON THE TEMPERATURE OF CALCITE PRECIPITATION.

TWM-USGS GCP-27, RO, DETERMINATION OF TEMPERATORE AND SALINITY FROM

THE CROSHING TEST RROVIDES A QUALITATIVE ESTIMATE OF THE GAS RRESSORE WITHIN A VAPOR INCLUSION AT THE TIMES OF CROSHING. OPTICAI MEASUREMENTS ARE MADE TO ESTABIISH THE APPROXIMATE VOLUME OF THE INCLOSION BEFORE CROSHING AND THE VOIOME PERCENT OF THE ORIGINAI VOLOME. THE VOLOME DECREASE IS A FUNCTION OF VAPOR PRESSURE OF WATER IN THE VAPOR PHASE AT THE TIME OF TRAPPING (AND HENCE, THE TEMPERATORE OF TRAPRING). 
SITE CHARACTERIZATION PLAN BASELINE

DATA TRACKING NO. TITLE/DESCRIPTION

*GS950608315215.002 STRONTIOM ISOTOPE RATIOS AND ISOTOPE DILUTION DATA FOR RUBIDIOM AND STRONTIUM COLLECTED $9 / 7 / 94$ TO 5/4/95

ACQN/DEVI IOCATION : OSGS, DENVER, CO

*GS950608315215.003 LETTER REPORT ON FY1995 STUDIES OF PALEODISCHARGE, BY JAMES C. PACES

ACON/DEVL LOCATION : USGS, DENVER, CO

Activity - 8.3.1.6.3.1.1

$\star \star G S 900908316311.001$ PRELIMINARY ASSESSMENT OF THE RISK OF VOLCANISM AT A PROPOSED NOCLEAR WASTE REPOSITORY IN THE SOUTHERN GREAT BASIN, BY BROCE M. CROWE AND W.J. CARR

ACQN/DEVL LOCATION : OSGS, DENVER, CO

\section{ACQN/DEVL PERIOD}

$09 / 07 / 94-05 / 04 / 95$

ACON/DEVI METHOD

$\begin{array}{lll}D & Q \\ A & 0 & -1 \\ 1 & A & 0\end{array}$

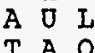

A L C

OSGS TECHNICAI PROCEDURE GCP-12,R4: RB-SR ISOTOPE GEOCHEMISTRY

$04 / 01 / 95-06 / 26 / 95$ THIS REPORT CONTAINS A SUMMARY OF THE SAMPIED FROM THE AMARGOSA DESERT DEPOSITS INCLUDING SAMPLE IOCATIONS, BRIEF SAMPLE INCLUDING SAMPLE LOCATIONS, BRIEF SAME DESCRIRTIONS, AND TABOLATION OF THE PERTINENT ANALYTICAL RESULTS, A SUM THE CALCDLATED AGE ESTIMATES AND AN ESTIMATES.

$01 / 01 / 78-12 / 13 / 80$ USGS STANDARD COLLECTION METHODS, REPORT SUMMARIZES THE STATUS OF THE VOLCANIC HAZARD STUDY. 
DATA TRACKING NO.

TITLE/DESCRIPTION

ACQN/DEVI PERIOD

08/20/93-09/15/93 STUDIES OF THE EFFECTS OF MAGMATIC ACTIVITY, INCLODING INITIAL RESULTS OF FIELD ANALOG STODIES AT SMALI VOLUME BASAITIC CENTERS AND NEW 3-DIMENSIONAI MODELING TECHNIOUES, ARE DISCOSSED AND IMPLICATIONS DEVELOPED.

ACQN/DEVL IOCATION : IOS AIAMOS NATIONAI LABORATORY

Activity -8.3 .1 .8 .1 .2 .2$

*LA000000000066.001 EFFECTS OF MAGMATIC PROCESSES ON THE POTENTIAL YOCCA MOUNTAIN REPOSITORY: FIELD AND COMPOTATIONAL STUDIES

$08 / 20 / 93-09 / 15 / 93$

TUDIES OF THE EFFECTS OF MAGMATIC ACTIVITY, INCLUDING INITIAL RESULTS OF FIELD ANALOG STODIES AT SMALL VOLOME BASAITIC CENTERS AND NEW 3-DIMENSIONAI MODELING TECHNIQUES, ARE DISCUSSED AND IMPIICATIONS DEVELOPED.

ACQN/DEVL LOCATION : LOS ALAMOS NATIONAL LABORATORY

Activity -8.3 .1 .8 .5 .1 .4$

*LA000000000099.001 GEOCHEMISTRY OF THE LATHROP WELLS VOLCANIC CENTER

07/01/90-08/01/94 XRF ANALYSIS, INSTRUMENTAL NEUTRON ACTIVATION ANALYSIS, SOIID-SODRCE MASS ACTIVATION ANAIYSIS, SOI MICROPROBE ANAIYSIS

ACQN/DEVL LOCATION : LANI 
SITE CHARACTERIZATION PILAN BASELINE

DATA TRACKING NO.

Activity - 8.3.1.8.5.2.3

**G930208318523.001 TEMPERATURE AND THERMAI CONDUCTIVITY IN WELLS NEAR YOCCA MOUNTAIN.

ACQN/DEVL LOCATION : UE-25 A\#I

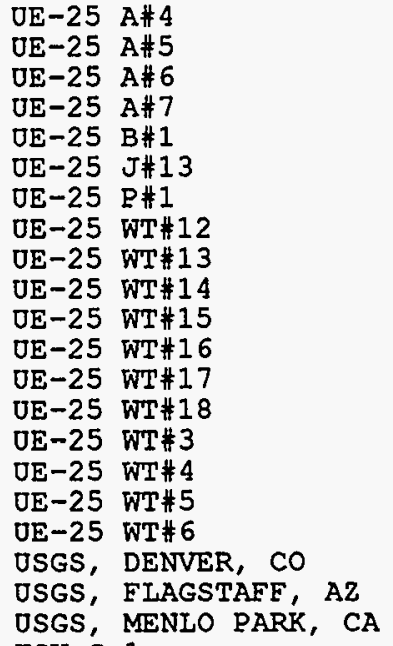

USGS, MENLO PARK, CA USW G-1

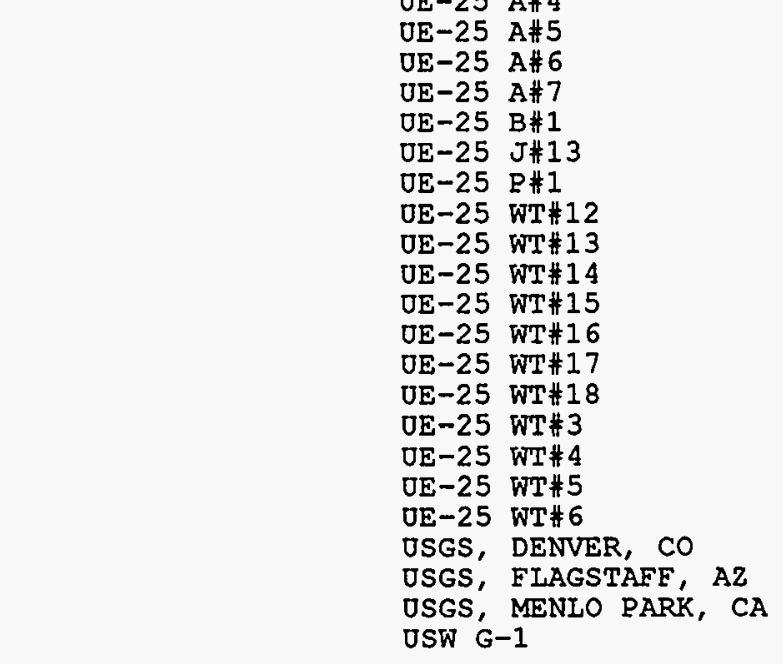

ACON/DEVI PERIOD

ACQN/DEVL METHOD

$09 / 01 / 80-06 / 30 / 84$

TEMPERATURE MEASOREMENTS IN AIR BY 1) SASS, J.H. \& OTHERS, 1971, HEAT FLOW IN THE WESTERN O.S.: JOURNAL OF GEOPHYSICAI RESEARCH, V.76, P.6376-6413, AND 2) TECHNICAL RROCEDORE NWM-OSGS GPP-02, R0, HEAT-FLOW STUDIES RELATED TO NOCLEAR WASTE STORAGE INVESTIGATIONS. THERMAI

CONDOCTIVITY BY 1) SASS, J.H. \& OTHERS 1984, LABORATORY LINE-SOORCE METHODS FÓ THE MEASOREMENT OF THERMAI CONDUCTIVITY OF ROCKS NEAR ROOM TEMPERATURE: OSGS OFR $84-91,2$ ) SASS \& OTHERS, 1971, OR. CIT. 3) SASS, J.H. \& OTHERS, 1980, ANALYSIS Ó THERMAI, DATA FROM DRIII HOIES OE25A-3 AND THERMAL DATA FROM DRILL HOLES OE2 SA-3 AND OE25A-1, CALICO HILLS \& YM, NTS: USGS OFR STUDIES CALIBRATION PROCEDORES 
SITE CHARACTERIZATION PIAN BASELINE

TITLE/DESCRIPTION

ACON/DEVL PERIOD

ACON/DEVL METHOD
DATA TRACKING NO.

DSW G-2

DSW G-3

OSW G-4

OSW $\mathrm{GO}-3$

USW $\mathrm{H}-1$

OSW $\mathrm{H}-3$

OSW $\mathrm{H}-4$

OSW H-5

OSW $\mathrm{H}-6$

OSW $02-1$

USW WT-1

OSW WT-10

USW WT-11

USW WT-2

USW WT-7

**GS950108314212.001 MAJOR RESULTS OF REGIONAL GEOPHYSICAL INVESTIGATIONS AT YOCCA MOONTAIN AND VICINITY, NEVADA, H.W. OLIVER, D.A.

PONCE, AND W.C. HUNTER, EDITORS

ACQN/DEVL LOCATION : USGS, MENLO PARK, CA

*GS950408318523.001 TEMPERATORE, THERMAL CONDOCTIVITY, AND HEAT FLOW NEAR YOCCA MOUNTAIN, NEVADA: HEAT FLOW NEAR YOCCA MOUNTAI
SOME TECTONIC AND HYDROIOGIC

SOME TECTONIC AND HYDROIOGIC

IMPLICATIONS, BY J.H. SASS, A.H.

LACHENBROCH, W.W. DODLEY, JR., S.S.

PRIEST, AND R.J. MONROE.

ACQN/DEVI LOCATION : OSGS, DENVER, CO

OSGS, FLAGSTAFF, AZ
08/01/87-12/30/94 DESCRIPTION OF INVESTIGATIONS FOCUSING ON D N P GRAVITY, MAGNETIC, MAGNETOTELLORIC,

SEISMIC REFRACTION, SEISMIC REFLECTION AND TELESEISMIC STODIES. THE GEOIOGIC AND REGIONAI THERMAI SETTINGS AS WELI AS STRESS MEASUREMENTS ARE INCLODED.

01/01/87-12/01/87 HEAT FLOW ESTIMATES BY 1) LEAST-SQUARES GRADIENT * HARMONIC MEAN OF MEASURED CONDOCTIVITIES OVER SAME INTERVAI, 2) CONDOCTIVITIES OVER SAME INTERVAI, 2) CALCOLATED FROM FORMATION MEANS, AND 3) IEAST-SQDARES GRADIENT * HARMONIC MEAN OF CONDUCTIVITIES INEERRED FROM $K$ VS. V RELATION. 
SITE CHARACTERIZATION PLAN BASELINE

DATA TRACKING NO.

TITLE/DESCRIPTION

Activity - 8.3.1.9.2.1.1

**GS941108319211.002 LEAD ISOTOPE RATIOS AND ISOTOPE DILOTION DATA FOR URANIUM, THORIOM, AND LEAD, APRIL TO JOLY 1994.

ACQN/DEVI LOCATION : OSGS, DENVER, CO

**GS941108319211.003 OXYGEN ISOTOPE DATA ON TIVA CANYON TOFF FROM ANTIER RIDGE SECTION

ACQN/DEVL PERIOD

ACQN/DEVL METHOD

04/16/94-07/15/94 OSGS TECHNICAL PROCEDURE GCP-13,R2: O-TH-PB ISOTOPE GEOCHEMISTRY

A Y T

$12 / 22 / 93-02 / 10 / 94$ DATA WERE COLLECTED BY APPROVED SUPPLIER, KROGER ENTERPRISES, GEOCHRON LABORATORIES (ASI-34), OSING GEOCHRON IAABS STANDARD OPERATING PROCEDURES PER PO-162841-94

ACQN/DEVL LOCATION : KRUGER ENT. GEOCHRON LABS, CAMBRIDGE, MASSACHOSETTS

$\star \star G S 941208319211.004$ OXYGEN ISOTOPE DATA ON TOFE BRECCIA SAMPLES FROM TRENCH 14 AND BOSTED BDTTE

07/01/94-07/29/94 DEPT. OF GEOIOGICAI SCIENCES, ONIVERSITY OF SASKATCHEWAN STANDARD OPERATING

ACQN/DEVL LOCATION : UNIV. OF SASKATCHEWAN, SASKATOON, CANADA

INAA ELEMENTAL ANALYSES OF TIVA CANYON TOFE (UPPER CLIFF AND CAPROCK ZONES)

$07 / 14 / 94-08 / 03 / 94$ APPROVED SOPPLIER, ACTIVATION IABORATORIES IIMITED, OSING THEIR STANDARD OPERATING PROCEDURES (PER 94-PO-0008) 
DATA TRACKING NO.

TITLE/DESCRIPTION

ACQN/DEVL PERIOD

ACQN/DEVL METHOD

$05 / 01 / 94-12 / 12 / 94$ OXYGEN ISOTORE DATA ON TUFF SAMPLES OF TIVA CANYON (UPPER CIIFE AND CAPROCK ZONES )

ACQN/DEVL LOCATION : UNIV. OF SASKATCHEWAN, SASKATOON, CANADA

*GS950208319211.003 OXYGEN ISOTOPES AND TRACE ELEMENTS IN TIVA CANYON TOFF IN THE VICINITY OF YOCCA MOONTAIN, NYE COUNTY, NEVADA, BY B.D. MARSHALI, T.K. KYSER, AND Z.E PETERMAN

ACQN/DEVL LOCATION : USGS, DENVER, CO

**GS950308319211.007 ACTIVATION LABORATORIES INAA ELEMENTAI

$09 / 26 / 94-10 / 18 / 94$ APPROVED SUPPIIER, ACTIVATION LABORATORIES LIMITED, OSING THEIR STANDARD LABORATORY OPERATING PR 94-PO-0008

THE STODY OF 0200 SAMPLES COLLECTED FROM OUTCROP INVOLVED AN ISOTOPIC APPROACH DEVEIOPED IN THE O.S. AND COMMONLY USED IN AOSTRAIIA FOR DETECTING ANY EVIDENCE OF POSSIBLE RAST INTERACTION OE VOLCANIC ROCKS WITH HYDROTHERMAI SOLUTIONS. THE STUDY ALSO ENTAILED A MORE CONVENTIONAI MINERAL EXPLORATION APPROACH INVOLVING ANALYSES OF MAJOR AND TRACE ELEMENTS IN THE TUEF INCLUDING PRECIOUS METALS AS WELI AS PATHFINDER ELEMENTS COMMONLY ASSOCIATED WITH PRECIOOS METAL MINERALIZATION IN NEVADA.
A $\mathrm{Y} T$ APPROVED SOPPIIER, DEPT. OF GEOLOGICAL OSING THEIR STANDARD OPERATING PROCEDORES ANAIYSES OF DRILI CORE SAMPLES FROM USW

G-2

ACQN/DEVL LOCATION : ACTIVATION LABS ITD., ANCASTER, CANADA 
Activity - 8.3.1.9.2.1.3

**GS950308319213.001 PREVIOOSLY ONPUBLISHED DOWNHOLE TEMPERATORE DATA FOR WELLS NEAR OR AT YOCCA MOUNTAIN, NEVADA - LOGGED FROM MAY 179 TO DEC. ' 81. DATA ARE THE LOGGED TEMPERATURES, MINIMUM AND MAXIMOM, OF THE BOREHOLE.

ACQN/DEVL LOCATION : UE-25 A\# USW $\mathrm{G}-1$

**GS950308319213.002 RREVIOOSLY ONPOBLISHED DOWNHOLE TEMPERATORE DATA FOR WELLS NEAR OR AT YOCCA MOONTAIN, NEVADA - LOGGED FROM JAN.' 82 TO SEPT.' 85 . DATA ARE THE IOGGED TEMPERATORES, MINIMUM AND MAXIMUM, OF THE BOREHOLE.

\section{ACQN/DEVL LOCATION : UE-25 B\#I} OE-25 P\#1 OSW G-2 OSW $G-3$

DSW G-4

OSW $\mathrm{H}-1$

OSW $\mathrm{H}-3$

OSW $\mathrm{H}-5$

OSW $H-6$
ACQN/DEVI PERTOD

ACQN/DEVL METHOD

$05 / 10 / 79-12 / 30 / 81$ MEASUREMENT OF SUBSURFACE TEMPERATORE AS DESCRIBED IN SASS, ET AL., 1971, HEATFLOW IN THE WESTERN ONITED STATES: JOURNAI OF GEOPHYSICAL RESEARCH, V.76, P.6376-6413, AND SASS, ET AL., 1981, HEAT FLOW FROM THE CROST OF THE UNITED STATES, IN TOULOUKIAN, ET AI, EDITORS, PHYSICAL PROPERTIES OF ROCKS AND MINERALS: MCGRAW-HILL, NY, P. 503-548

01/13/82-09/11/85 NWM-USGS GPP-02,R0, (EFFECTIVE 1/11/82) A N T HEAT FLOW STUDIES RELATED TO NOCLEAR WASTE STORAGE INVESTIGATIONS, AND NWM-OSGS GRP-05, RO, (EFFECTIVE 7/9/84) HEAT FLOW STODIES CALIBRATION PROCEDORE.
A N T 
SITE CHARACTERIZATION PLAN BASELINE

DATA TRACKING NO. TITLE/DESCRIPTION

\section{ACQN/DEVL PERIOD}

ACON/DEVL METHOD

P $\quad$ E 0

Activity - 8.3.1.14.2.2

**SNF29041993002.029 YOCCA MOONTAIN SITE CHARACTERIZATION MESA AND RANIER MESA TUFFS. (THIS DATA

$09 / 15 / 93-04 / 20 / 94$ IS IN APPENDIX $C$ OF SLTR94-0001, "SOIIS LABORATORY AND IN SITO TEST DATA", ISSOED $10 / 04 / 94)$.

(1)

THE FOLLOWING STANDARD TESTING METHODS WERE OSED TO PERFORM SOIL CHARACTERIZATIO AND STRENGTH TESTS: ASTM $C-2216-90$, ASTM D-2216-93, AND ASTM C-566-89 (MOISTORE CONTENT); ASTM C-136-84A, ASTM D-422-63, AND ASTM D-422-90 (SIEVE ANALYSIS); ASTM D-1140-54, ASTM D-1140-90, AND ASTM D-1140-92 (PASSING \#200); ASTM D-2434-68 (REAPPROVED 1974) (SOII PERMEABILITY TO MERCORY TAP WATER); ASTM D-1196-87 (BEARING CAPACITY OF SOIL FOR STATIC LOAD) ASTM D-2922-91 AND ASTM D-3017-88

(NOCLEAR DENSITY); AND ASTM D-1188-89 (BULR DENSITY OF ROCK); ASTM D-1556-90 (SAND CONE DENSITY) ; ASTM 1452-90, ASTM 1586-84, AND ASTM 2488-90 (LOG OF BORING-PENETRATION TEST); ASTM D-854-91 AND ASTM $C-127 / \mathrm{C}-128-88$ (SPECIFIC GRAVITY)

ACQN/DEVI IOCATION : NTS/AREA 25/NRT-1 TRENCH; MATERIAL TEST LABORATORY

- MERCORY, NV 
Activity - 8.3.1.14.2.3

**SNF29041993002.026 SLTR94-0001: "YOCCA MOUNTAIN SITE CHARACTERIZATION PROJECT GEOENGINEERING CHARACTERTZATION OF NONLITHIFIED TOFFS TO BE ENCOONTERED BY THE NORTH RAMP WEST OF THE BOW RIDGE FAOLT" (FINAL REPORT).

ACQN/DEVI LOCATION : SNL, JFTA, ONR, GEOMATRIX, \& RSN MTL

YOCCA MOONTAIN SITE CHARACTERIZATION PROJECT SOII TEST DATA FOR RRE-RANIER MESA AND RANIER MESA TO IS IN APPENDIX C, OF SITR94-0001, "SOILS LABORATORY AND IN SITO TEST DATA", ISSUED $10 / 04 / 94$ ).

$09 / 15 / 93-04 / 20 / 94$

THE FOLLOWING STANDARD TESTING METHODS WERE OSED TO PERFORM SOIL CHARACTERIZATION AND STRENGTH TESTS: ASTM C-2216-90, ASTM D-2216-93, AND ASTM C-566-89 (MOISTORE CONTENT); ASTM C-136-84A, ASTM D-422-63, AND ASTM D-422-90 (SIEVE ANALYSIS): ASTM D-1140-54, ASTM D-1140-90, AND ASTM D-1140-92 (PASSING \#200); ASTM D-2434-68 (REAPPROVED 1974) (SOIL PERMEABILITY TO MERCURY TAP WATER); ASTM D-1196-87

(BEARING CAPACITY OF SOII FOR STATIC LOAD) - ASTM D-2922-91 AND ASTM D-3017-88 (NOCLEAR DENSITY): AND ASTM D-1188-89 (BOLK DENSITY OF ROCK); ASTM D-1556-90 (SAND CONE DENSITY); ASTM 1452-90, ASTM 1586-84, AND ASTM 2488-90 (LOG OF BORING-PENETRATION TEST); ASTM D-854-91 AND ASTM C-127/C-128-88 (SRECIFIC GRAVITY) 
SITE CHARACTERIZATION PLAN BASELINE

DATA TRACKING NO.

TITLE/DESCRIPTION

ACQN/DEVI PERTOD

ACON/DEVL METHOD

E D N

*SNE29041993002.031 YOCCA MOONTAIN SITE CHARACTERIZATION PROJECT ROCK MASS MECHANICAI PROPERTIES ESTIMATES FOR BOREHOLES OE25 NRG-1, NRG-2, NRG-2A, NRG-3, NRG-4, NRG-5; USW NRG-2, NRG-2A, NRG-3, NRG-4, NRG-5; USW
NRG-6, AND NRG-7/7A (REVISION 2). THIS IDENTIFIED BY DTN: SNE29041993002.012. PTN THERMOMECHANICAI ONITS HAVE BEEN SOPERSEDED BY DTN ID: SNE29041993002.049. THIS DATA HAS BEEN SUPERSEDED BY TWO SEPARATE TDIFS ON 6/5/95, DTN: SNF29041993002.062

(QOALIFIED DATA, THERMOMECHANICAI ONITS: DO TUFE, TCW, TSW1, TSW2) AND SNE29041993002.064 (ONQUALIFIED DATA THERMOMECHANICAI ONITS: TSW1 AND TSW2)

ACQN/DEVI LOCATION : J.F.T. AGAPITO

**SNE29041993002.045 SEISMIC RESEARCH FOR EXILE HILI, NYE COONTY, NEVADA.

A COMMON DEPTH POINT SEISMIC SURVEY WAS CONDUCTED USING A SLEDGE HAMMER SOURCE. THE PROCEDORE FOR THIS IS OUTLINED IN THE SCIENTIFIC NOTEBOOK.

ACQN/DEVI LOCATION : WEST SIDE OF EXILE HILI, NYE COUNTY, NV

**SNF29041993002.046 ESF NORTH RAMP YUCCA MOUNTAIN SITE CHARACTERIZATION PROJECT CROSS SECTION CHARACTERTZATION PROJECT CROSS SE

INTERPRETATION OF EXILE HILI GEOLOGY DRAWING NO: SITREXS2, VERSION: 0 , $12 / 10 / 93$

$12 / 02 / 93-12 / 10 / 93$

MODIFICATION OF EXISTING GEOLOGIC INTERPRETATION BASED ON SEISMIC REFLECTION DATA OF GREGORY J. ELBRING (1994).

ACQN/DEVI IOCATION : J.F.T. AGAPITO 


\section{DATA TRACKING NO.}

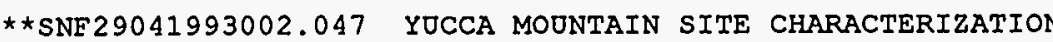
PROJECT ESTIMATED ROCK MASS QUALITY INDICES BASED ON REVISION 2 FOR CORE LOG DATA HOLES OE25 NRG-1, -2A, -3 , AND -5 ; AND REVISION 3 FOR OE25 NRG-2, $-2 B,-4$ AND OSW NRG-6 AND 7/7A. (THIS DATA SOPERSEDES DATA PREVIOUSLY IDENTIFIED BY DTN'S: SNE29041993002.011 SNF 29041993002.017 , AND SNE29041993002.019)

ACQN/DEVL LOCATION : J.F.T. AGAPITO

**SNF29041993002.048 YUCCA MOUNTAIN SITE CHARACTERIZATION PROJECT CORE HOLE ROCK STROCTORAL DATA SUMMARIES FOR BOREHOLES OE25 NRG-1, -2, $-2 \mathrm{~A},-2 \mathrm{~B},-3,-4,-5$; AND DSW NRG-6 \& $7 / 7 A$, REVISION 1 ;. (THIS DATA SOPERSEDES DATA PREVIOUSLY IDENTIFIED BY DTN: SNE29041993002.009, SNE29041993002.016 AND SNE29041993002.018, WITH THE EXCEPTION OF THE DATA FOR BOREHOLE RE \#8, WHICH WAS OSED FOR CORROBORATING PORPOSES ONLY)

ACQN/DEVL LOCATION : J.E.T. AGAPITO

**SNE29041993002.049 YOCCA MOUNTAIN SITE CHARACTERIZATION PROJECT ROCK MASS MECHANICAI PROPERTIES ESTIMATES FOR BOREHOLES OE25 NRG-1, -2, $-2 A,-3,-4,-5$, DSW NRG- 6 , $7 / 7$ A REVISION 3 . (THIS DATA SUPERSEDES THE VALOES FOR THE PTN THERMOMECHANICAL ONITS ONLY IN THE DATA PREVIOOSLY ONITS ONLY IN THE DATA PRE 1903002.031 IDENTIFIED BY DTN: SNF 29041993002.031. ALL OTHER THERMOMECHANICAL ONIT VALUES IN THE PREVIOOS DATA REMAIN THE SAME.) THIS DATA HAS BEEN SOPERSEDED
SNF29041993002.063 ON $6 / 5 / 95$.
ACON/DEVI PERIOD

ACQN/DEVL METHOD

E D N

11/01/93-02/13/95 THE \& AND RMR WERE ESTIMATED OSING ROCK STROCTORAI DATA SUMMARIES DEVELORED FROM STROCTORAI LOGGING OF CORE, OBSERVATIONS OF ROCK CONDITIONS IN THE NORTH RAMP STARTER TUNNEL AND LABORATORY TEST DATA ON CORE.

$11 / 01 / 93-02 / 04 / 95$ GEOTECHNICAI CORE LOGGING OF UE25 NRG-1, $-2,-2 \mathrm{~A},-2 \mathrm{~B},-3,-4,-5$; USW NRG-6 $7 / 7 A$. PREPARED IN ACCORDANCE WITH SCIENTIEIC NOTEBOOK FOR GEOTECHNICAL LOGGING OF CORE BY EXAMINATION OF CORE AND VIDEO RECORDS FROM NRG HOLES, AND INSTRUCTIONS FOR ESTABITSHING OA RECORDS BASED URON T\&MSS ROCK STRUCTURE LOGS.

11/01/93-02/10/95 BASED ON ROCK MASS QOALITY INDICES FOR NRG D Y C HOLES, AND ROCK MECHANICS LABORATORY TEST RESOLTS. 
DATA TRACKING NO.

TITLE/DESCRIPTION

ACQN/DEVI PERIOD

ACON/DEVL METHOD

ACQN/DEVL LOCATION : J.F.T. AGAPITO

**SNF29041993002.050 YOCCA MOONTAIN SITE CHARACTERIZATION PROJECT RANK-ORDERED ROCK MASS OUAIITY INDICES FOR PTN ONITS, REVISION 1. (THIS DATA SOPERSEDES THE VALDES FOR THE PTN THERMOMECHANICAI DNTTS ONLY IN THE DATA RREVIOOSLY IDENTIFIED BY DTN: SNE2 29041993002.032 . ATT OTHER THERMOMECHANICAL ONIT VALOES REMAIN THE SAME)

ACON/DEVL LOCATION : J.F.T. AGAPITO

**SNE29041993002.051 YUCCA MOONTAIN SITE CHARACTERIZATION PROJECT GEOLOGY AND ROCK STRUCTORE LOG FOR HOLE OSW SD-9, 700-850 FT, REV.0

$11 / 01 / 94-02 / 22 / 95$

GEOTECHNICAL CORE LOGGING OF OSW SD-9 PREPARED IN ACCORDANCE WITH SCIENTIFIC NOTEBOOK FOR GEOTECHNICAI LOGGING OF CORE BY EXAMINATION OF CORE AND VIDEO RECORDS FROM SD-9 HOLE, INSTRDCTIONS FOR ESTABLISHING OA RECORDS BASED OPON M\&O ROCK STRUCTORE IOGS.

ACON/DEVL LOCATION : J.F.T AGAPITO AND YMP SAMPIE MANAGEMENT FACIITTY

**SNE29041993002.052 YUCCA MOONTAIN SITE CHARACTERIZATION PROJECT CORE HOLE ROCK STRUCTORAL DATA SUMMARY FOR HOLE OSW SD -9 , REV. 0

ACQN/DEVI LOCATION : J.F.T AGAPITO 01/01/95-02/22/95 GEOTECHNICAI CORE LOGGING OF OSW SD-9.
PREPARED IN ACCORDANCE WITH SCIENTIFIC NOTEBOOK FOR GEOTECHNICAL LOGGING OF CORE NYTEBOOK FOR GEOTECHNICAI LOGGING RE CORE FROM SD -9 HOI OE INSTROCTIONS FOR ESTABISHING OA RECORDS BASED UPON M\&O ESTABLISHING QA RECORD
ROCK STROCTORE LOGS. 
* SNF 29041993002.053 YUCCA MOUNTAIN SITE CHARACTERIZATION PROJECT ESTIMATED ROCK MASS QUALITY INDICES BASED ON CORE LOG DATA FOR HOLE USW SD-9, MIDDLE NONLITHOPHYSAL ZONE, REV. 0

ACQN/DEVI LOCATION : J.E.T. AGAPITO

* *SNF 29041993002.054 YOCCA MOUNTAIN SITE CHARACTERIZATION PROJECT GEOLOGY AND ROCK STROCTURE LOG FOR DRILLHOIE OSW SD-12, 650-800 FT, REV. 0 .

$11 / 01 / 94-02 / 22 / 95$

GEOTECHNICAL CORE LOGGING OF OSW SD-12. PREPARED IN ACCORDANCE WITH SCIENTIFIC NOTEBOOK FOR GEOTECHNICAI LOGGING OF CORE BY EXAMINATION OF CORE AND VIDEO RECORDS FROM SD-12 HOLE. INSTROCTIONS FOR ESTABIISHING QA RECORDS BASED UPON M\&O ROCK STROCTORE LOGS.

ACON/DEVI LOCATION : J.F.T. AGAPITO AND YMP SAMPLE MANAGEMENT FACIIITY

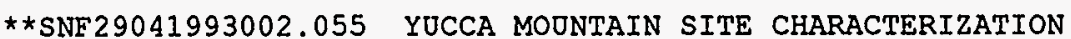
RROJECT CORE HOLE ROCK STRUCTORAI DATA SUMMARY FOR HOLE OSW SD-12, REV. 0

ACON/DEVL LOCATION : J.F.T AGAPITO
$01 / 01 / 95-02 / 22 / 95$

GEOTECHNTCAI CORE LOGGING OF OSW SD-12. PREPARED IN ACCORDANCE WITH SCIENTIFIC NOTEBOOKS FOR GEOTECHNICAL LOGGING OF CORE BY EXAMINATION OF CORE AND VIDEO RECORDS FROM SD-12 HOLE. INSTRUCTIONS FOR ESTABLISHING QA RECORDS BASED UPON MEO ROCK STROCTURE LOGS. 
DATA TRACKING NO.

**SNF29041993002.056 YUCCA MOUNTAIN SITE CHARACTERIZATION PROJECT ESTIMATED ROCK MASS OUALITY INDICES BASED ON CORE LOG DATA FOR HOLE OSW SD-12, MIDDLE NONLITHOPHYSAL ZONE, REV 0 .

ACQN/DEVI IOCATION : J.F.T. AGAPITO

* *SNE 29041993002.057 YUCCA MOUNTAIN SITE CHARACTERIZATION PROJECT ROCK MASS MECHANICAI PROPERTIES ESTIMATES FOR TOPORAH SPRING, MIDDLE NONLITHOPHYSAI ZONE (BASED ON ESTIMATES FOR OSW NRG-6\&7/7A, SD-9 \& SD-12), REV 0 .

ACQN/DEVL LOCATION : J.F.T. AGAPITO

* $\star$ SNE 29041993002.058 YOCCA MOONTAIN SITE CHARACTERIZATION PROJECT RANK-ORDERED ROCK MASS OOAIITY INDICES $Q$ AND ROD FOR BOREHOIES NRG-6, NRG-7/7A, SD-9 AND SD-12, REV. 0 .

ACQN/DEVL LOCATION : J.E.T. AGAPITO

*SNE29041993002.059 YUCCA MOONTAIN SITE CHARACTERIZATION PROJECT COMPARISON OF DOWNHOLE VIDEO DATA WITH CORE DATA FOR HOL

ACQN/DEVI LOCATION : J.F.T. AGAPITO

-5 , OSW NRG-6, -7/7A, REV 0
ACQN/DEVI PERIOD

ACQN/DEVI METHOD

$01 / 01 / 95-02 / 22 / 95$

Q AND RMR ESTIMATED OSING ROCK STRDCTORAI DATA SUMMARY DEVELORED FROM STRUCTURAI

IOGGING OF CORE USW SD-12 DRILLHOLE.

OBSERVATIONS OF ROCK CONDITIONS IN THE

NORTH RAMP STARTER TUNNEL AND ILABORATORY TEST DATA ON CORE.

$02 / 01 / 95-02 / 28 / 95$

BASED ON ROCK MASS QUALITY INDICES FOR NRG-6, NRG-7/7A, SD-9 \& SD-12, AND ROCK MECHANICS IAABORATORY TEST RESULTS.

02/01/95-02/28/95 THE O AND ROD WERE CALCULATED USING ROCK STROCTURAI DATA SUMMARIES DEVELOPED FROM STRUCTORAI LOGGING OF CORE FROM OSW NRG-6 NRG-7/7A, SD-9 AND SD-12 DRILLHOLES: OBSERVATION OF ROCK CONDITIONS IN ; NORTH RAMP STARTER TUNNEL; AND LABORATORY TEST DATA ON CORE.

08/01/94-11/01/94 VISUAI ESTIMATES OF BOREHOLE WALI PARAMETERS (ITTHOPHYSAE CONTENT, SIZE SHAPE AND BOREHOIE SHAPE) FROM DOWNHOI VIDEO IOGS ARE COMPARED WITH ROCK STROCTURAI DATA (ROD, COST CORE, RUBBLE AND $\%$ IITHOPHAYSAE) 
SITE CHARACTERIZATION PLAN BASELINE

DATA TRACKING NO.

02/09/95-03/29/95 ASTM D-1194 (87) "STANDARD TEST METHOD FOR A Y P BEARING CAPACITY OF SOII FOR STATIC LOAD AND SPREAD FOOTINGS", ASTM D-1586 (92) "PENETRATION TESTS AND SPIIT BARREI SAMPLING OF SOILS".

ACON/DEVL LOCATION : RAYTHEON SERVICES NEVADA \& SNL

* SNE2 29041993002.061 PREIIMINARY SOII SUCTION TEST DATA INCLUDED IN SLTR94-0001: "YOCCA INCLUDED IN SLTR94-0001: "YOCCA
MOUNTAIN SITE CHARACTERIZATION PROJECT MEONTAIN SITE CHARACTERIZAIION OF GEOENGINEERING CHARACO THE NORTH RAMP WEST OF THE BOW RIDGE FAULT" (PAGES 5-19 THROUGH 5-21, AND IN APPENDIX A, SECTION A.1.3)

ACQN/DEVL LOCATION : ONIVERSITY OF NEVADA, RENO

*SNF29041993002.062 ROCK MASS MECHANICAL PRORERTIES ESTIMATES FOR BOREHOLES OE 25 NRG $-1,-2$ $-2 A,-3,-4,-5 ;$ OSW NRG-6, -7/7A. '(THIS TATOS PRTVTOUSIY DATA SUPERSEDES THE VAT BY DTN: SNF29041993002.031)

ACQN/DEVL LOCATION : J.F.T. AGAPITO

*SNF29041993002.063 ROCK MASS MECHANICAL RROPERTIES ESTIMATES FOR OE25 NRG-4 AND USW NRG -6, $-7 / 7$ A. THIS DATA SUPERSEDES DATA PREVIODSIY IDENTIFIED BY DTN : SNE29041993002.049.

ACQN/DEVL LOCATION : J.F.T. AGAPITO
05/01/94-06/15/94 THE SOIL SOCTION DATA WAS DEVELOPED IN ACCORDANCE WITH ASTM D5298-92: "STANDARD ACCORDANCE WITH ASTM DS298-92: "STAMD POTENTIAI (SOCTION) OSING FILTER PAPER".
11/01/93-05/31/95 BASED ON ROCK MASS QOAIITY INDICES FOR NRG D Y $P$ HOLES AND ROCK MECHANICS LABORATORY TEST RESULTS
$11 / 01 / 93-05 / 31 / 95$

BASED ON ROCK MASS QUALITY INDICES FOR NRG D Y P HOLES AND ROCK MECHANICS LABORATORY TEST RESOLTS 
DATA TRACKING NO

11/01/93-05/31/95 BASED ON ROCK MASS QOALITY INDICES FOR NRG D N P HOLES AND ROCK MECHANICS LABORATORY TEST

ROCK MASS MECHANICAL PROPERTIES

ESTIMATES FOR BOREHOLES OE25 NRG $-1,-2$

$-2 A,-3,-4,-5 ;$ OSW NRG $-6,-7 / 7 A$.

THIS DATA SOPERSEDES DATA PREVIOUSLY

IDENTIFIED BY DTN: SNE29041993002.031. RESOLTS.

ACQN/DEVI LOCATION : J.F.T. AGAPITO

Activity - 8.3.1.15.1.1.1

**SNL04050593001.001 WHOLE ROCK CHEMICAL ANALYSES -

"LABORATORY PETROIOGIC DETERMINATION OF

10/01/93-10/31/94 WHOLE ROCK CHEMICAL ANALYSES SAMPLES FROM NRG-6"

ACQN/DEVL LOCATION : SANDIA NATIONAL LABORATORIES, ALBOQUERQOE, NM O.N.M., ALBOQOERQUE, NM

Activity - 8.3.1.15.1.2.1

*SNL01B05059301.004 THERMAI EXPANSION CURVES FOR OSW NRG-6 SAMPLES.

04/06/95-05/08/95 SINGLE-ROD DILATOMETER

ACQN/DEVL LOCATION : HOLOMETRIX, BEDFORD, MA 
SITE CHARACTERIZATION PLAN BASELINE

DATA TRACKING NO.

TITLE/DESCRIPTION

ACQN/DEVL PERIOD

ACON/DEVL METHOD

$8 / 23 / 94-01 / 25 / 95$

MECHANICAI PROPERTIES DATA /OLTRASONIC VELOCITIES, STATIC ELASTIC RROPERTIES TRIAXIAL STRENGTH, DRY BOLK DENSITY POROSITY) FOR DRILLHOLE OSW NRG SAMPI

FT.

ACQN/DEVL LOCATION : NER, INC., WHITE RIVER JUNCTION, VERMONT

* *SNL02030193001.022 MECHANICAI PROPERTIES DATA (ULTRASONIC VELOCITIES, STATIC ELASTIC PROPERTIES TRIAXIAL STRENGTH, DRY BOLK DENSITY \& POROSITY) FOR DRILI HOLE USW NRG-6 SAMPLES FROM DEPTH $5.7 \mathrm{FT}$. TO $1092.3 \mathrm{FT}$.

$08 / 23 / 94-02 / 23 / 95$

ASTM STM D2845-90: "LABORATORY

DETERMINATION OF POLSE VELOCITIES AND OLTRASONIC ELASTIC CONSTANTS OF ROCK, ISRM "SOGGESTED METHODS FOR DETERMINING THE STRENGTH OF ROCK IN TRIAXIAI COMPRESSION: REVISED VERSION 1983," AND ASTM STM "TEST METHOD FOR SPECIFIC GRAVITY OF SOILS."

Activity - 8.3.1.15.1.3.1

ASTM STM D2845-90: "LABORATORY OITRASONIC ELASTIC CONSTANIS OF ROCK," ISM "SUGGESTED METHODS FOR DETERMINING COMPRESSION: REVISED VERSION 1983 " "AND ASTM STM D854-92: "TEST METHOD FOR

SPECIFIC GRAVITY OF SOILS."

ACQN/DEVL LOCATION : NER, INC., WHITE RIVER JUNCTION, VERMONT 
Activity - 8.3.1.15.1.3.2

**SNL02030193001.021 MECHANICAL PROPERTIES DATA (OLTRASONIC VELOCITIES, STATIC ELASTIC PROPERTIES, TRIAXIAL STRENGTH, DRY BOLK DENSITY \& POROSITY) FOR DRILLHOLE DSW NRG-7/7A SAMPLES FROM DEPTH 345.0 FT. TO 1408.6 FT.

$08 / 23 / 94-01 / 25 / 95$ ASTM STM D2845-90: "LABORATORY DETERMINATION OF POLSE VELOCITIES AND ISRM "SOGGESTED METHODS FOR DETERMINING THE STRENGTH OF ROCK MATERIALS IN TRIAXIAI COMPRESSION: REVISED VERSION 1983, "AND ASTM STM D854-92: "TEST METHOD FOR SPECIFIC GRAVITY OF SOILS."

ACQN/DEVL LOCATION : NER, INC., WHITE RIVER JUNCTION, VERMONT

**SNL02030193001.022 MECHANICAL PROPERTIES DATA (OLTRASONIC VELOCITIES, STATIC ELASTIC PROPERTIES TRIAXIAL STRENGIH, DRY BULK DENSITY \& POROSITY) FOR DRILL HOLE OSW NRG-6 SAMPLES FROM DEPTH 5.7 FT. TO 1092.3 FT.

$08 / 23 / 94-02 / 23 / 95$

DETERMINATION OF PULSE VELOCITIES AND OLTRASONIC EIAATIC CONSTANTS OF ROCK," ISRM "SUGGESTED METHODS FOR DETERMINING THE STRENGTH OF ROCK IN TRIAXIAI COMPRESSION: REVISED VERSION 1983," AND ASTM STM "TEST METHOD FOR SPECIFIC GRAVITY OF SOILS."

ACQN/DEVI LOCATION : NER, INC., WHITE RIVER JUNCTION, VERMONT 
SITE CHARACTERIZATION PLAN BASEIINE

DATA TRACKING NO. TITLE/DESCRIRTION

Activity - 8.3.1.15.1.4.2

**SNL02112293001.002 RESULTS FROM SHEAR STRESS EXPERIMENTS ON

NATURAI FRACTORES FROM NRG-7.

08/01/94-03/03/95 TESTS.

ACQN/DEVL METHOD ACQN/DEVL LOCATION : SANDIA NATIONAI LABORATORIES, ALBOQOERQOE, NM

**SNL02112293001.003 RESULTS FROM SHEAR STRESS EXPERIMENTS ON NATURAL FRACTURES FROM NRG-4 \& NRG-6.

08/11/94-02/01/95 SCIENTIFIC NOTEBOOK FOR NRG FRACTURE TESTS.

ACQN/DEVL IOCATION : SANDIA NATIONAI LABORATORIES, ALBOQDERQDE, NM

Activity - 8.3.1.15.1.8

*SNF 32120393001.001 ROCK MASS QUAIITY DATA FOR THE NRT

01/25/95-03/20/95 VISUAL INSPECTION OF TUNNEI WALIS. STATIONS 60 TO 475 METERS. COLLECTION AND REDUCTION OF DATA BY

ACQN/DEVL LOCATION : NORTH RAMP TUNNEL STATIONS 60-475 METERS

*SNF 32120393001.002 ROCK MASS QOALITY DATA FOR THE NRT STATIONS 475 TO 530 METERS

$03 / 20 / 95-03 / 29 / 95$

VISUAL INSPECTION OF TONNEI WALLS COLLECTION AND REDDCTION OF DATA BY TECHNICAI INSTRUCTION TI 019.A02.

ACQN/DEVI LOCATION : NORTH RAMP TUNNEL STATIONS 475 TO 530 METERS

*SNF 32120393001.003 ROCK MASS QOALITY DATA FOR THE NRT STATIONS 530 TO 600 METERS
$03 / 29 / 95-04 / 29 / 95$

VISOAL INSPECTION OF TUNNEL WALLS COLLECTION AND REDUCTION OF DATA BY TECHNICAI INSTRUCTION TI $019 . A 02$ 
ROCK MASS QOALITY DATA FOR THE NRT STATIONS 600 TO 655 METERS
05/01/95-05/05/95 VISUAL INSPECTION OF TONNEL WALLS.

COLIECTION AND REDUCTION OF DATA BY TECHNICAI INSTRUCTION TI019.A02.

ACQN/DEVL LOCATION : NORTH RAMP TONNEL STATIONS 600 TO 655 METERS

*SNE 32120393001.005 ROCK MASS OOAITTY DATA FOR THE NRT ROCK MASS QUALITY DATA FOR
STATIONS 655 TO 705 METERS

05/08/95-05/12/95

ACQN/DEVL LOCATION : NRT STATIONS 655 TO 705 METERS

*SNE 32120393001.006 ROCK MASS QUALITY DATA FOR THE NRT

STATIONS 702 TO 767 METERS

$05 / 08 / 95-05 / 12 / 95$

ACQN/DEVL LOCATION : NRT STATIONS 702 TO 767 METERS

Activity - 8.3.1.15.1.8.4

*SNE34011895001.001 DIESEL EXHAOST CONSTITUENT DATA IN THE ESE NORTH RAMP.

ACQN/DEVI LOCATION : YOCCA MOUNTAIN ESF NORTH RAMP RORTAI
04/29/95-04/29/95 ENERAC DATA: PLOTS: ENERGY EFEICIENT

SYSTEMS MODEL 3000 ENGINE ANALYZER; DATA; PLOTS-SNL-CAMPBELL CR-10 DATA LOGGER, TECO MODEI 42 NO \& NO2 ANALYZER, TECO MODEI 48 CO ANALYZER, TECO MODEL 43A SO2 ANALYZER, NOVA CO2 ANALYZER, AIR FIOW RATE MEASUREMENTS: TEMP-VAISAIAA FM1-31, R.H. VAISALA MODEL HM1-31, BAROMETRIC PRESSORE AIR MODEI AIR-HB-1A. 
Activity - 8.3.1.15.2.2.1

**GS950108314212.001 MAJOR RESOLTS OF REGIONAL GEOPHYSICAL INVESTIGATIONS AT YOCCA MOUNTAIN AND VICINITY, NEVADA, H.W. OLIVER, D.A. PONCE, AND W.C. HONTER, EDITORS

ACQN/DEVI IOCATION : USGS, MENLO PARK, CA

*GS950483115221.001 TEMPERATURE LOG DATA OBTAINED IN WELL OSW G-2, FEBROARY, 1995.

$02 / 01 / 95-02 / 01 / 95$ ACQN/DEVL LOCATION : USW G-2

Activity - 8.3.1.16.1.1.1

**GS920183116111.001 UNNAMED TRIBUTARY FROM PINE NOT MTS. TO CARSON RIVER AT FREMONT DRIVE. PEAK FLOW ESTIMATES DATA INCLUDE STREAM-CHAMTEI DISCRART DISCIARGE ESTIMATES. RECORD INCLUDES 1989) SITE IOCATION MAP, AND PHOTOGRAPH(S) OF DATA COLLECTION SITE.

$08 / 01 / 87-12 / 30 / 94$ GRAVITY, MAGNETIC, MAGNETOTELLORIC TEIESEISMIC STODIES. THE GEOIOGIC AND AND REGIONAI THERMAI SETTINGS AS WELI AS STRESS MEASOREMENTS ARE INCLUDED.

\section{$08 / 07 / 91-08 / 07 / 91$}

ACQN/DEVL LOCATION : $3901^{\prime} 32^{\prime \prime N} 11942^{\prime} 31^{\prime \prime W}$

**GS920183116111.004 JUMBO CREEK AT NEW WASHOE CITY, NV. PEAK FLOW ESTIMATES. DATA INCLODE

$08 / 05 / 91-08 / 05 / 91$ STREAM-CHANNEI MEASOREMTNTS AND DISCHARGE ESTIMATES, RECORD INCLODES SLOPE CONVEYANCE FIELD FORM (NV-300-03, SLORE CONVEYANCE FIELD FORM PHOTOGRAPH (S) OF DATA COLLECTION SITE. ACQN/DEVL LOCATION : $3916^{\prime} 58^{\prime \prime N} 11944^{\prime} 50^{\prime \prime} \mathrm{W}$ INDIRECT METHOD FOR DETERMINING PEAK DISCHARGE OF A STREAM. THIS METHOD USES STREAM CHANNEI MEASUREMENTS AND ESTIMATED FIOW VELOCITY TO COMPUTE THE PEAK DISCHARGE OF A STREAM AFTER THE STREAMFIOH

DETAIL IN HP-114, RO, SECTION 4.2.2.

$\mathrm{GPP}-20, \mathrm{R3}-\mathrm{MI}$ DISCHARGE OF A STREAM. THIS METHOD OSES STREAM CHANNEL MEASUREMENTS AND ESTIMATED FLOW VELOCITY TO COMPOTE THE PEAK DISCHARGE OF A STREAM AFTER THE STREAMFLOW DIAS RECEDED. DETAII IN HP- 114, RO, SECTION 4.2 .2 . 
DATA TRACKING NO.

**GS920183116111.005 ONNAMED WASH JOST SOOTH OF HOT SPRINGS MOUNTAIN, CARSON VAIIEY, NV, PEAK FION ESTIMATES. DATA INCLODE STREAM-CHANNEI

$08 / 07 / 91-08 / 07 / 91$

INDIRECT METHOD FOR DETERMINING PEAK DISCHARGE OF A STREAM. THIS METHOD USES STREAM CHANNEI MEASUREMENTS AND ESTIMATED FLOW VELOCITY TO COMPOTE THE PEAK MEASUREMENTS AND DISCHARGE ESTIMATES. RECORD INCLODES SLOPE CONVEYANCE FIELD FORM (NV-300-03, 1989), SITE IOCATION MAP.

ACQN/DEVI LOCATION : $3902^{\prime} 46^{\prime \prime N} 11942^{\prime} 51 " \mathrm{~W}$

**GS920183116111.006 JNNAMED TRIBOTARY TO WASHOE I.AKE FROM VIRGINIA RANGE NEAR NEW WASHOE CITY, NV. PEAR FIOW ESTIMATES. DATA INCLODE' STREAM-CHANNEL MEASUREMENTS AND

DISCHARGE ESTIMATES. RECORD INCLODES DISCHARGE ESTIMATES . RECORD INCIODES
SLORE CONVEYANCE FIEID FORM (NV-300-03,

1989), SITE LOCATION MAP, AND
PHOTOGRAPH(S) OF DATA COLLECTION SITE.

ACQN/DEVL LOCATION : $3917^{\prime} 35^{\prime \prime N} 11946^{\prime} 06^{\prime \prime} \mathrm{W}$

Activity - 8.3.1.17.3.1.1

*GS950583117311.001 QUATERNARY FAOLTS AS RELEVANT EARTHQUAKE SOORCES IN THE YOCCA MOONTAIN REGION, BY SILVIO PEZZORANE.

ACQN/DEVL LOCATION : OSGS, DENVER, CO

08/05/91-08/05/91 INDIRECT METHOD FOR DETERMINING PEAK DISCHARGE OF A STREAM. THIS METHOD USES STREAM CHANNEI MEASOREMENTS AND ESTIMATED FIOW VELOCTTY TO COMPOTE THE PEAR

DISCHARGE OF A STREAM AFTER THE STREAMFION HAS RECEDED. THIS METHOD IS DESCRIBED IN DETAIL IN HP-114, R0, SECTION 4.2.2.

AS RECEDED. DETAII IN HP-114, RO, SECTION 4.2.2

\section{A Y C}


**GS910183117412.009 EARTHQOAKE DATA - DECEMBER 7-11, 15-19 AND 25-29, 1990, AND DECEMBER 31, 1990 JANOARY 22, 1991. DEVELOCORDER FILM.

ACON/DEVL LOCATION : SOOTHERN GREAT BASIN SEISMIC NETWORK

**GS910283117412.006 EARTHQUAKE DEVELOCORDER FILMS. DECEMBER 11-DECEMBER 15, 1990, DECEMBER

19-DECEMBER 25, 1990 DECEMBER

29-DECEMBER 31, 1990, JANOARY 22-JANDARY

28, 1991, FEBROARY 1-FEBROARY 3, 1991

AND FEBROARY 5 - FEBROARY 13, 1991.

$12 / 07 / 90-12 / 11 / 90$ $12 / 15 / 90-12 / 19 / 90$ $12 / 25 / 90-12 / 29 / 90$ $12 / 31 / 90-01 / 22 / 91$

SP-11, R2, OPERATION AND CALIBRATION OF REMOTE TELEMETERED SEISMIC ARRAY

$12 / 11 / 90-12 / 15 / 90$ $12 / 19 / 90-12 / 25 / 90$ $12 / 29 / 90-12 / 31 / 90$ $01 / 22 / 91-01 / 28 / 91$ $02 / 01 / 91-02 / 03 / 91$ $02 / 05 / 91-02 / 13 / 91$

ACQN/DEVL LOCATION : SOUTHERN GREAT BASIN SEISMIC NETWORK

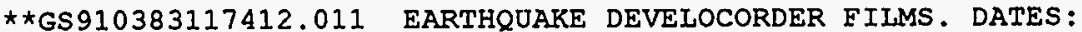
JANDARY 28 - FEBROARY 1 FEBRDARY 3 - 5,

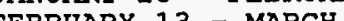

$01 / 28 / 91-02 / 01 / 91$ $02 / 03 / 91-02 / 05 / 91$ $02 / 13 / 91-03 / 07 / 91$

SR-11, R2, OPERATION AND CAIIBRATION OF REMOTE TELEMETERED SEISMIC ARRAY

SP-11,R2, OPERATION AND CAIIBRATION OF REMOTE TELEMETERED SEISMIC ARRAY

ACQN/DEVL LOCATION : SOUTHERN GREAT BASIN SEISMIC NETWORK

* *S910383117412.012 DEVELOCODER FILMS, 27 BOXES, MARCH 7 TO MARCH 25, 1991 - EARTHQUAKE DEVELOCODER

$03 / 07 / 91-03 / 25 / 91$ SOUTHERN GREAT BASIN SEISMIC NETWORK.
A $X$ C ILM.

ACON/DEVL LOCATION : SOUTHERN GREAT BASIN 
DATA TRACKING NO.

TITLE/DESCRIPTION

ACQN/DEVI PERIOD

ACQN/DEVL METHOD

03/29/91-04/26/91 SP-11,R2, OPERATION AND CALIBRATION OF REMOTE TELEMETERED SEISMIC ARRAY $03 / 29 / 91-04 / 26 / 91$

ACQN/DEVI LOCATION : SOUTHERN GREAT BASIN SEISMIC NETWORK

**GS910583117412.016 20 SOUTHERN GREAT BASIN LOCAL EARTHQUAKE ARCHIVE TAPES NOMBERED: L033-L041, L043, I044, L045, L091, L095, L460, L461,

I480, I490, I091, I095, TA60, I $161,10 / 83$

TO $12 / 28 / 84$.

ACQN/DEVI LOCATION : SOUTHERN GREAT BASIN

**GS910583117412.017 31 SOUTHERN GREAT BASIN LOCAL EARTHQUAKE ARCHIVE TAPES NOMBERED: L501-L504, L506-L532. DATES: $1 / 1 / 85-1 / 1 / 86$.

ACQN/DEVL LOCATION : SOUTHERN GREAT BASIN

**GS910583117412.018 40 SOUTHERN GREAT BASIN LOCAL EARTHQOAKE ARCHIVE TAPES NUMBERED: L600-I639. DATES : $1 / 2 / 86-12 / 31 / 86$.

ACQN/DEVL LOCATION : SOUTHERN GREAT BASIN

**GS910583117412.036 EARTHQOAKE DEVEIOCORDER FIIMS. DATES: MAY 2, 1991 - MAY 14, 1991 (18 BOXES).

ACQN/DEVL LOCATION : SOUTHERN GREAT BASIN SEISMIC NETWORK
01/02/86-12/31/86 SOUTHERN GREAT BASIN SEISMIC NETWORK.

$05 / 02 / 91-05 / 14 / 91$

01/10/83-12/28/84 SODTHERN GREAT BASIN SEISMIC NETWORK.

$01 / 01 / 85-01 / 01 / 86$ SOUTHERN GREAT BASIN SEISMIC NETWORK. REMOTE TELEMETERED SEISMIC ARRAY 
**GS910583117412.044 34 SOUTHERN GREAT BASIN LOCAI EARTHQUAKE ARCHIVE TAPES NOMBERED: L001-I032, L054 AND L059. DATES: $9 / 16 / 81-12 / 30 / 82$.

ACQN/DEVL LOCATION : SOUTHERN GREAT BASIN

$\star \star G S 910683117412.038$ EARTHQUAKE DEVELOCORDER. DATES: MAY 16, 1991 - MAY 30, 1991, JONE 1, 1991-JUNE $11,1991$.

ACQN/DEVL LOCATION : SOUTHERN GREAT BASIN

**GS910783117412.041 EARTHQDAKE DEVELOCORDER FILMS. DATES: JUNE 13, 1991 - JONE 27, 1991, AND JUNE

$06 / 13 / 91-06 / 27 / 91$ $06 / 29 / 91-07 / 01 / 91$

SP-11,R2, ORERATION AND CALIBRATION OF REMOTE TELEMETERED SEISMIC ARRAY 29,1991 - JULY 1, 1991

ACON/DEVL LOCATION : SOUTHERN GREAT BASIN SEISMIC NETWORK

$* \star$ GS 910883117412.042 EARTHQUAKE DEVELOCORDER FILMS 60 BOXES
DATES: JOIY 3, 1991 - ADGOST i2, 1991.

ACQN/DEVL LOCATION : SOUTHERN GREAT BASIN

**GS910983117412.046 EARTHQUAKE DEVELOCORDER FILMS. 27 BOXES. DATES: AOGOST 12-AUGOST 30, 1991.

08/12/91-08/30/91 SOOTHERN GREAT BASIN SEISMIC NETWORK.

A N C

ACQN/DEVL LOCATION : SOUTHERN GREAT BASIN 
SITE CHARACTERIZATION PLAN BASEIINE

DATA TRACKING NO. TITLE/DESCRIPTION

ACQN/DEVL PERIOD

ACQN/DEVI, METHOD

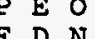

**GS910983117412.049 EARTHQOAKE DEVELOCORDER FILMS FOR DATES ADGOST 30, 1991 TO SERTEMBER 9, 1991.

ACQN/DEVL LOCATION : SOUTHERN GREAT BASIN

**GS910983117412.050 EARTHQUAKE DEVELOCORDER FIIMS FOR DATES SEPTEMBER 9, 1991 TO SEPTEMBER 27, 1991.

ACQN/DEVL LOCATION : SOUTHERN GREAT BASIN.

**GS911083117412.051 EARTHQDAKE DEVEIOCORDER FILMS OF THE SOUTHERN GREAT BASIN FOR DATES SEPTEMBER SOUTHERN GREAT BASIN FOR DATES SEPTEMBER
27 THRODGH OCTOBER 11, 1991 .

ACQN/DEVL LOCATION : SOUTHERN GREAT BASIN

**GS911083117412.052 EARTHQUAKE DEVELOCORDER EILMS OF THE SOOTHERN GREAT BASIN FOR DATES OCTOBER 11 THROOGH OCTOBER 25, 1991.

ACQN/DEVL IOCATION : SOUTHERN GREAT BASIN

**GS911183117412.054 EARTHQUAKE DEVEIOCORDER EILM OF THE SOOTHERN GREAT BASIN FOR THE DATES OCTOBER 25 THROOGH NOVEMBER $16,1991$.

ACQN/DEVL LOCATION : SOUTHERN GREAT BASIN
08/30/91-09/09/91 SODTHERN GREAT BASIN SEISMIC NETWORK

09/09/91-09/27/91 SOUTHERN GREAT BASIN SEISMIC NETWORK.

A Y C

09/27/91-10/11/91 SOOTHERN GREAT BASIN SEISMIC NETWORK 


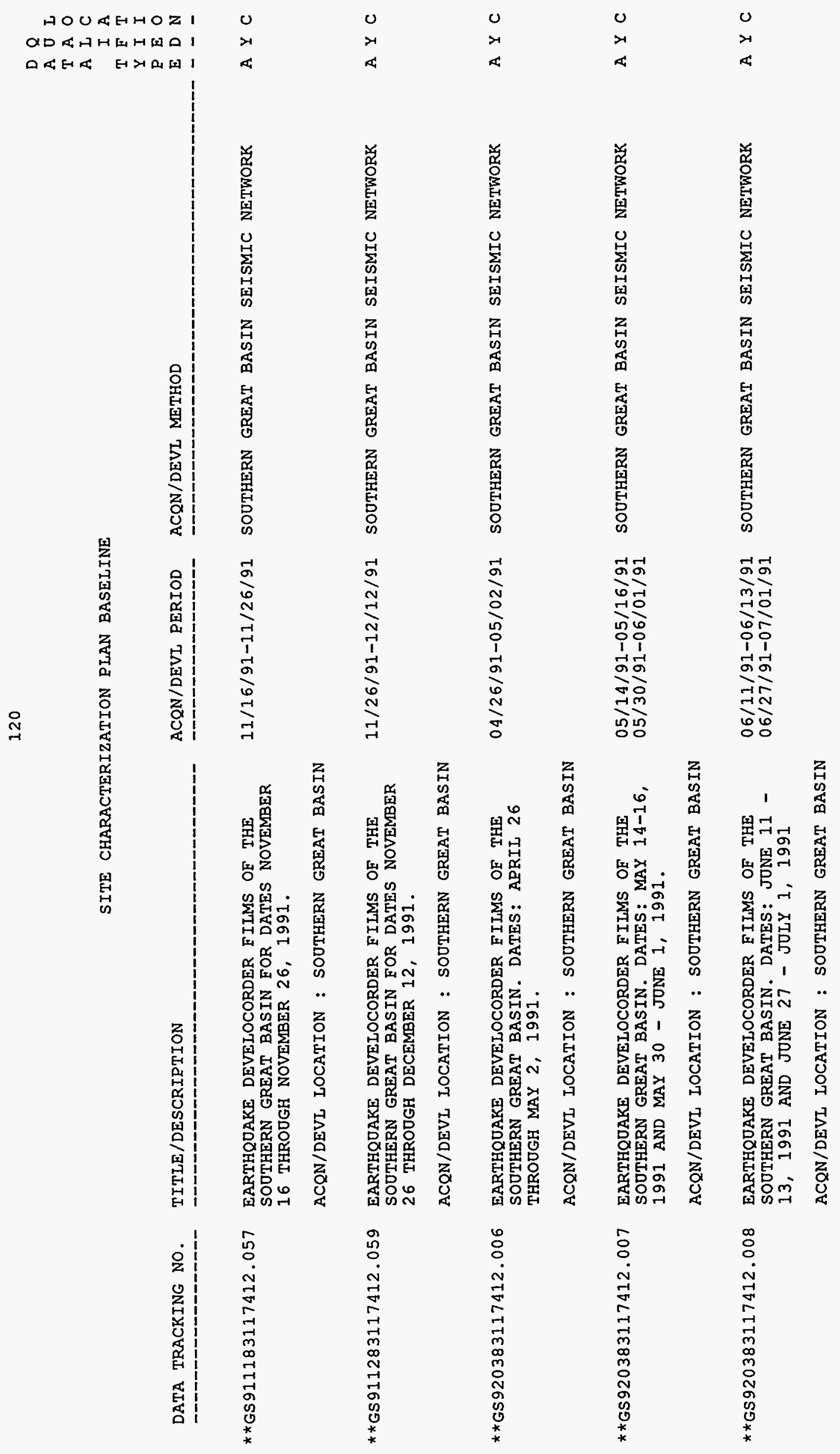


DATA TRACKING NO.

TITLE/DESCRIPTION

ACQN/DEVL, PERIOD

ACON/DEVL METHOD

07/01/91-07/03/91 SOUTHERN GREAT BASIN SEISMIC NETWORK

A Y C

EARTHQOAKE DEVEIOCORDER FIIMS OF THE SOOTHERN GREAT BASIN. DATES: JOLY $1-3$ 1991.

ACQN/DEVL IOCATION : SOUTHERN GREAT BASIN

**GS920883117412.027 SEISMIC AFTERSHOCK RECORDINGS OF THE IITTLE SKOLL MOONTAIN EARTHQOAKE OF JUNE 29, 1992: JNRSL SEGMENT 1, JONE 30, 1992 - JULY 14, 1992.

ACON/DEVL LOCATION : $36.7229 \mathrm{~N} 116.1288 \mathrm{~W}$ $36.6646 \mathrm{~N} 116.2041 \mathrm{~W}$ $36.6646 \mathrm{~N} 116.2041 \mathrm{~W}$ $36.6206 \mathrm{~N}$
$36.716 .2117 \mathrm{~N}$
$116.2223 \mathrm{~W}$ $\begin{array}{ll}36.7285 \mathrm{~N} & 116.2223 \mathrm{~W} \\ 36.7779 \mathrm{~N} & 116.2868 \mathrm{~W}\end{array}$ $36.7379 \mathrm{~N} 116.2868 \mathrm{~W}$ $36.7764 \mathrm{~N} 116.3747 \mathrm{~W}$ $36.8531 \mathrm{~N} 116.4237 \mathrm{~W}$ $36.8557 \mathrm{~N} 116.4430 \mathrm{~W}$ $36.8371 \mathrm{~N} 116.4683 \mathrm{~W}$ $36.8286 \mathrm{~N} 116.6326 \mathrm{~W}$ $36.8539 \mathrm{~N} 116.6442 \mathrm{~W}$

**GS920983117412.029 SEISMIC AFTERSHOCK RECORDINGS OF THE IITTLE SKOLI MOONTAIN EARTHOOAKE OF JUNE LITTLE SKOLI MOONTAIN EARTHQOAKE OF JO $29,1992:$
1992 - MAYY $15,1993$.

ACON/DEVI LOCATION : $36.7229 \mathrm{~N} 116.1288 \mathrm{~W}$ $36.6646 \mathrm{~N} 116.2041 \mathrm{~W}$ $36.6206 \mathrm{~N} 116.2117 \mathrm{~W}$ $36.7285 \mathrm{~N}$
$36.716 .2223 \mathrm{~W}$ $36.7779 \mathrm{~N} 116.2868 \mathrm{~W}$ $36.7339 \mathrm{~N} 116.3161 \mathrm{~W}$ $36.7261 \mathrm{~N} 116.3275 \mathrm{~W}$ $36.8531 \mathrm{~N} 116.4237 \mathrm{~W}$ $36.8557 \mathrm{~N} 116.4430 \mathrm{~W}$ $36.8543 \mathrm{~N} 116.4520 \mathrm{~W}$ $36.8371 \mathrm{~N} 116.4$ $36.8371 \mathrm{~N} 116.4683 \mathrm{~W}$ $36.8310 \mathrm{~N} 116.4688 \mathrm{~W}$
06/30/92-07/14/92 DEPLOYMENT OF PORTABLE SEISMOGRAPHS IN ACCORDANCE WITH SN-0007.
07/15/92-05/15/93 DEPIOYMENT OF PORTABLE SEISMOGRAPHS IN ACCORDANCE WITH SN-0007, TWO-DIMENSIONAI ACCORDANCE WITH SN-0007, TWO-DIMENSIOI MEISMIC 


\section{$36.6865 \mathrm{~N} 116.5363 \mathrm{~W}$ \\ $36.8286 \mathrm{~N} 116.6326 \mathrm{~W}$ \\ $36.8539 \mathrm{~N} 116.6442 \mathrm{~W}$ \\ ONIVERSITY OE NEVADA-RENO SEISMOLOGY LABS} MECHANISMS FOR THE SOUTHERN GREAT BASIN OF NTVADA AND CATTFORNTA: JANOARY 1992

$05 / 01 / 93-10 / 13 / 93$ THRODGH SEPTEMBER 1992, BY S.C. HARMSEN

ACQN/DEVL LOCATION : USGS BELH, GOLDEN, CO

$\star \star$ GS 940683117412.005 NPE/RYAN REVERSED REFRACTION PROFILE DATA

ACQN/DEVL LOCATION : $36.31 \mathrm{~N} 116.88 \mathrm{~W}: 37.35 \mathrm{~N} 116.21 \mathrm{~W}$
1994 PORTABLE SEISMIC INSTROMENT DEPLOYMENTS: SEISMIC EVENT TAVEFORMS FOR TWO PORTABLE SEISMIC STATIONS IN THE ROCK VALLEY AREA

ACQN/DEVI LOCATION : $36 \quad 39^{\prime} 52.0 " \mathrm{~N} 11612^{\prime} 19.0 " \mathrm{~W}$ $3641,03.5^{\prime \prime N} 11612,57.9$ "W ONIVERSITY OF NEVADA-RENO SEISMOLOGICAL IABORATORY, RENO, NEVADA
01/01/94-12/31/94 DATA WAS COLLECTED BY TWO PORTABLE SEISMIC A Y C DATA WAS COLLECTED BY TWO PORTABLE SEI STATIONS WITH DIGITAL DATA ACQUISITION
SYSTEMS IN ACCORDANCE WITH SN-0047, ROCK SYSTEMS IN ACCORDANCE WITH SN-0O4 VALLEY EARTHQOAKES. DEPLOYMENT INFORMATION PERTINENT TO THE DATA THE SCIENTIFIC NOTEBOOK
WHICH OSED DIGITAL ACQOISITION HARDWARE

REFTEK AND EDA TO RECORD SEISMIC DATA.

SN-0051 RAINER MESA FIELD BOOK FOR NPE -

RYAN - REVERSED REFRACTION EXPERIMENT AND

SN-0052, JACKASS FLATS FIELD BOOK FOR NP
- RYAN - REVERSED REFRACTION EXPERIMENT 
SITE CHARACTERIZATION PLAN BASEIINE

DATA TRACKING NO.

*GS950383117412.005 YOCCA MODNTAIN AND CRATER FLAT REFRACTED ARRIVAIS FROM IITTIE SKOLL MOONTAIN AFTERSHOCKS: DATA PACKAGE AND FIEID DEPLOYMENT HISTORY

ACON/DEVL IOCATION : $36.8750 N 116.6740 \mathrm{~N}$ $36.8949 \mathrm{~N} 116.7350 \mathrm{~W}$ $36.8975 \mathrm{~N} 116.8102 \mathrm{~W}$ $36.9250 \mathrm{~N} 116.8650 \mathrm{~W}$ BEATTY, NV

SEISMIC AFTERSHOCK RECORDINGS OF THE IITTLE SKULI MOUNTAIN EARTHQOAKE OF JUN 29, 1992: UNRSL SEGMENT 3, MARCH 3 AOGUST 20, 1993 .

ACQN/DEVL LOCATION : $36.8750 \mathrm{~N} 116.6740 \mathrm{~W}$ $36.8949 \mathrm{~N} 116.7350 \mathrm{~N}$ 36.8975 N 116.8102 . 36.9250 N $116.8650 \mathrm{~W}$
$03 / 04 / 93-09 / 08 / 93$ THIS SEISMIC DATA WAS COILECTED BY EDA OR REFTEK DATA ACQUISITION SYSTEMS CONNECTED TO GORAIP OR GEOTECH SEISMIC SENSORS IN ACCORDANCE WITH SCIENTIFIC NOTEBOOK SN-0007, 2 DIMENSIONAI SETSMIC ARRAY MEASOREMENTS AT YOCCA MOUNTAIN.

$03 / 03 / 93-08 / 20 / 93$

DEPLOYMENT OF PORTABLE SEISMOGRAPHS IN ACCORDANCE WITH SN-0007, TWO-DIMENSIONAI SEISMIC ARRAY MEASOREMENTS AT YOCCA MOUNTAIN 


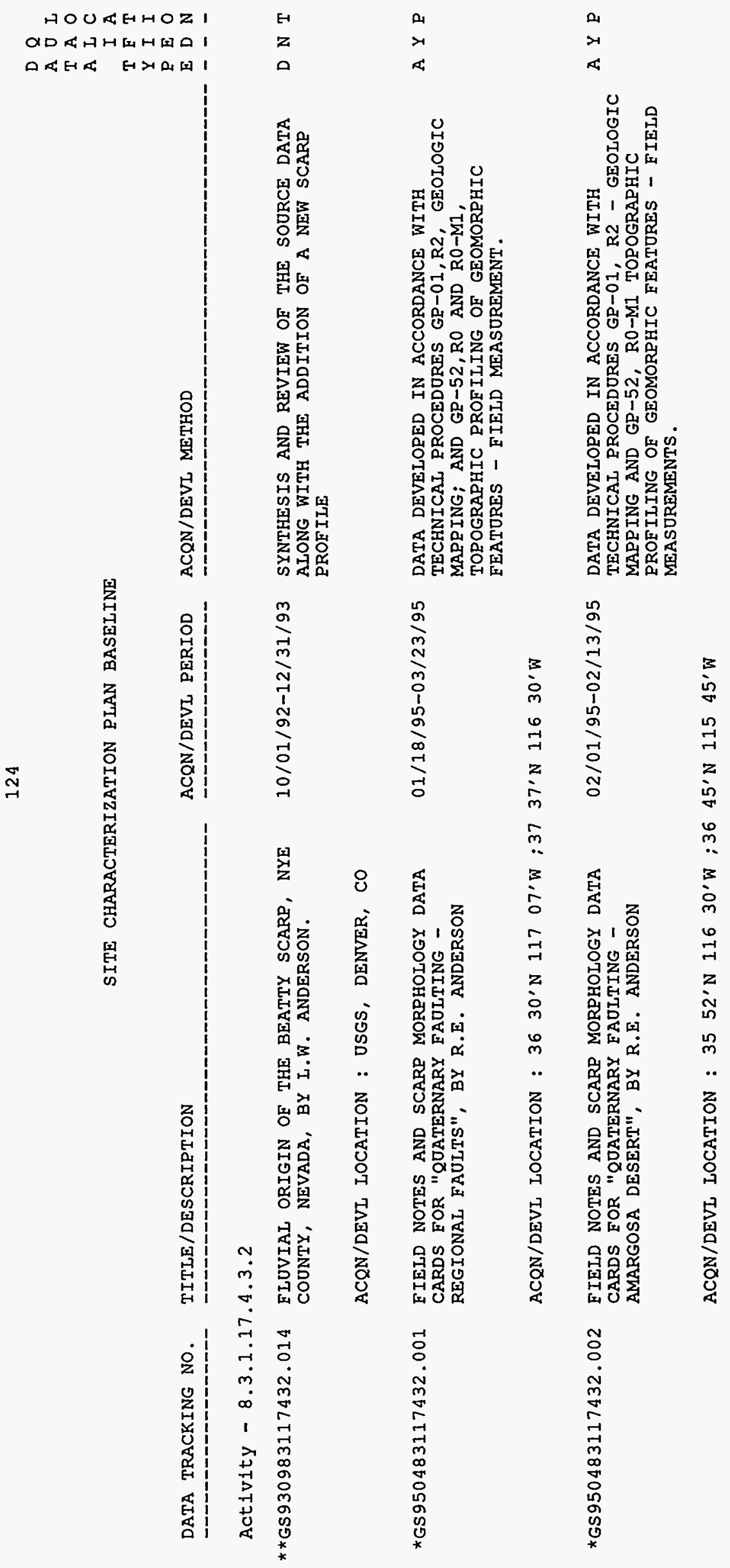


DATA TRACKING NO.

Activity - 8.3.1.17.4.5.2

*GS950483117452.001 FISSION-TRACK DATA ON SAMPLES FROM BARE MOUNTAIN AND BOLIEROG HIILS, NEVADA,

$10 / 06 / 94-03 / 04 / 95$

SAMPLES WERE ANAIYZED IN ACCORDANCE WITH

A Y P SAMPLES: FOSSIL-TRACK DENSITY \& COONTS,

INDUCED TRACK DENSITY \& COONTS, STANDARD

DENSITY AND CODNTS, ZETA AND AGE.

ACQN/DEVI LOCATION : USGS, DENVER, CO

Activity - 8.3.1.17.4.6.2

*GS950183117462.001 PALEOSEISMIC INVESTIGATIONS OF STAGECOACH ROAD FAULT, SOOTHEASTERN YOCCA MMOUNTAIN, NYE COONTY, NEVADA, BY MENGES, OSWAID, COE, IONDSTROM, PACES, MAHAN, AND WIDMAN

ACQN/DEVI LOCATION : USGS, LAS VEGAS, NV

*GS950583117462.002 BOREHOLE SAMPLE DESCRIPTIONS OF STAGECOACH ROAD BOREHOIES OE-25 SR\#1. SR\#2, AND SR\#3, BY C. MENGES AND $J$. OSWALD.

ACQN/DEVI LOCATION : SAMPLE MANAGEMENT FACIIITY, NTS, NV

*GS950683117462.003 PRELIMINARY TRENCH LOGS, JNIT \& SOIL DESCRIPTIONS AND TEXT FOR BDSTED BUTTE WAITS 12 AND 4 ON THE PATNTBROSH CANYON FAULT, BY $J$. COE, C. MENGES, AND J. WHITNEY

ACQN/DEVL, LOCATION : BBW1

BBW2
BBW3
09/12/94-09/16/94 ACCORDANCE WITH SCIENTIFIC NOTEBOOK
SN-0001D, IITHOLOGIC IOGGING METHODOLOGY.

$03 / 16 / 92-06 / 15 / 95$

03/01/94-12/15/94 METHOD INCLODES THE COMPILATION OF IOGS AND FIEID DESCRIPTIONS OF UNITS AND SOILS. THESE DAIA WERE INIERPREIED WITH RESPECI TO FAOLTING. THIS REPORT WAS PREPARED WITH LOGS PRESENTING THESE INTERPRETATIONS.

DATA WERE COLIECTED OSING TECHNICAL PROCEDORE GP-07,R1, CONVENTIONAL GEOLOGIC MAPPING OF TRENCH WALLS; AND GP-39, RO, GEOPHOTOGRAMMETRIC MAPPING OF TRENCH WALLS - FIELD WORK. 
Activity - 8.3.1.17.4.7.1

**GS950108314212.001 MAJOR RESULTS OF REGIONAL GEOPHYSICAL INVESTIGATIONS AT YOCCA MOUNTAIN AND VICINTTY NEVADA, YOCCA MOUNTAIN AND PONCE, AND W.C. HONTER, EDITORS

ACQN/DEVL LOCATION : USGS, MENLO PARK, CA Activity -8.3 .1 .17 .4 .7 .2$

**GS950108314212.001 MAJOR RESULTS OF REGIONAL GEOPHYSICAI INVESTIGATIONS AT YOCCA MOUNTAIN AND VICINITY, NEVADA, H.W. OIIVER, D.A. PONCE, AND W.C. HONTER, EDITORS

ACON/DEVL IOCATION : USGS, MENLO PARK, CA Activity - 8.3.1.17.4.7.3

**GS950108314212.001 MAJOR RESOLTS OF REGIONAL GEOPHYSICAL INVESTIGATIONS AT YUCCA MOONTAIN AND VICINITY, NEVADA, H.W! OLIVER, D.A. PONCE, AND W.C. HUNTER, EDITORS

$08 / 01 / 87-12 / 30 / 94$ DESCRIPTION OF INVESTIGATIONS FOCUSING ON GRAVITY, MAGNETIC, MAGNETOTELLURIC, SEISMIC REFRACTION, SEISMIC REFLECTION AND TELESEISMIC STODIES. THE GEOLOGIC AND REGIONAL THERMAI SETTINGS AS WELI AS STRESS MEASUREMENTS ARE INCLUDED.

ACQN/DEVI LOCATION : OSGS, MENLO PARK, CA 
SITE CHARACTERIZATION PLAN BASELINE

DATA TRACKING NO.

TITLE/DESCRIPTION

ACQN/DEVL PERIOD

ACQN/DEVI METHOD

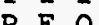

E D N

Activity - 8.3.1.17.4.8.1

**GS950108314212.001 MAJOR RESULTS OF REGIONAI GEOPHYSICAI INVESTIGATIONS AT YOCCA MOONTAIN AND VICINITY, NEVADA, H.W. OLIVER, D.A. PONCE, AND W.C. HUNTER, EDITORS

ACQN/DEVL LOCATION : USGS, MENLO RARK, CA

Activity - 8.3.1.17.4.10.1

**GS930731174101.004 GEODETIC LEVELING AND QDADRILATERAI SORVEYS (GPS OBSERVATIONS) 1990-1991: FINAI DATA ACQUISITION REPORT, BOOK 1 GARY C. PERASSO, P.I. - I.I. NEIFERT, LEVEL OBSERVER

ACQN/DEVL LOCATION : USGS, DENVER, CO

**GS950131174101.001 1994 YOCCA MOUNTAIN QOADRILATERAI MEASOREMENTS

ACQN/DEVL LOCATION : FRAN RIDGE NE
FRAN RIDGE NW
FRAN RIDGE SE
FRAN RIDGE SW
SOLITARIO NE
SOIITARIO NW
SOIITARIO SE
SOIITARIO SW
STAGE NE
STAGE NW
STAGE SE
STAGE SW
TRENCH $1 \mathrm{NE}$
TRENCH $1 \mathrm{NW}$
TRENCH $1 \mathrm{SE}$
TRENCH $1 \mathrm{SW}$
TRENCH $14 \mathrm{NE}$
TRENCH $14 \mathrm{NW}$
TRENCH $14 \mathrm{SE}$

08/01/87-12/30/94 DESCRIPTION OF INVESTIGATIONS FOCOSING ON D N P GRAVITY, MAGNETIC, MAGNETOTEILURIC, SEISMIC REERACTION, SEISMIC REFLECTION AND TELESEISMIC STODIES. THE GEOLOGIC AND REGIONAI THERMAL SETTINGS AS WELI AS STRESS MEASOREMENTS ARE INCLODED.

$11 / 30 / 90-07 / 31 / 93$

COMPILATION OF HEIGHT DATA, DESCRIPTIONS, NGS ELEVATIONS, AND QOADRILATERAIS; ALONG WITH SUMMARY AND STATOS REPORT BY P.I. AND PROJECT REPORT BY LEVEL OBSERVER

05/25/94-05/26/94 TECHNICAL PROCEDURE GP-06, R4, GEODETIC A $\Psi T$ 
SITE CHARACTERIZATION PLAN BASELINE

DATA TRACKING NO.

TITLE/DESCRIPTION

ACQN/DEVI PERIOD

ACQN/DEVL METHOD

12/14/94-04/19/95 TECHNICAL PROCEDURE GP-06,R4, GEODETIC LEVEIING AND QOADRILATERAI SORVEYS

\section{TRENCH $14 \mathrm{SW}$ RIDGE NE $\begin{array}{ll}\text { RIDGE } & S E \\ \text { RDGE } & S W\end{array}$}

1994 - 1995 YOCCA MOUNTAIN GEODETIC MEASUREMENTS.

ACQN/DEVL LOCATION : 1 BIS HN

$$
\begin{aligned}
& 1 \text { JD } \\
& 1 \text { PDI } \\
& 10 \text { TJS } \\
& 10 \text { TJS } \\
& 11 \mathrm{ANN} \\
& 11 \text { TJS } \\
& 12 \mathrm{~A} \mathrm{HN} \\
& 12 \text { TJS } \\
& 13 \mathrm{~A} \mathrm{HN} \\
& 13 \text { TJS } \\
& 14 \mathrm{~A} \text { HN } \\
& 14 \text { TJS } \\
& 15 \mathrm{~A} \mathrm{HN} \\
& 15 \text { TJS } \\
& 16 \text { A HN } \\
& 16 \text { TJS } \\
& 17 \mathrm{~A} \text { HN } \\
& 17 \text { TJS } \\
& 18 \mathrm{~A} \mathrm{HN} \\
& 18 \text { TJS } \\
& 19 \mathrm{~A} H N \\
& 19 \text { TJS } \\
& 2 \text { PDI } \\
& 2 \text { TJS } \\
& 20 \mathrm{~A} \text { HiN } \\
& 20 \text { TJS } \\
& 21 \text { A HN } \\
& 22 \mathrm{~A} H \\
& 22 \text { TJS } \\
& 23 \mathrm{~A} \mathrm{HN}
\end{aligned}
$$


SITE CHARACTERIZATION PIAN BASELINE

D 8

A O I

T A 0

A I C

I A

T F T

$Y$ I I

P

DATA TRACKING NO. TITLE/DESCRIPTION

23 TJS

24 TJS

25 TJS

26 TJS

26 TJS

27 TJS

28 TJS

29 TJS

2JD

$3 \mathrm{JD}$

3 PDI

3 TJS

30 TJS

31 TJS

32 TJS

33 TJS

34 TJS

35 TJS

36 TJS

37 TJS

38 TJS

38 TJS

39 TUS

4 PDI

40 TJS

40 TJS

42 TJS

43 TJS

44 TJS

45 TJS

46 TJS

47 TJS

49 TJS

49 TJS

5 PDI

50 TJS

50 TJS

51 TUS

52 TJS

53 TJS

54 TJS

55 TJS

56 TJS

57 TUS 


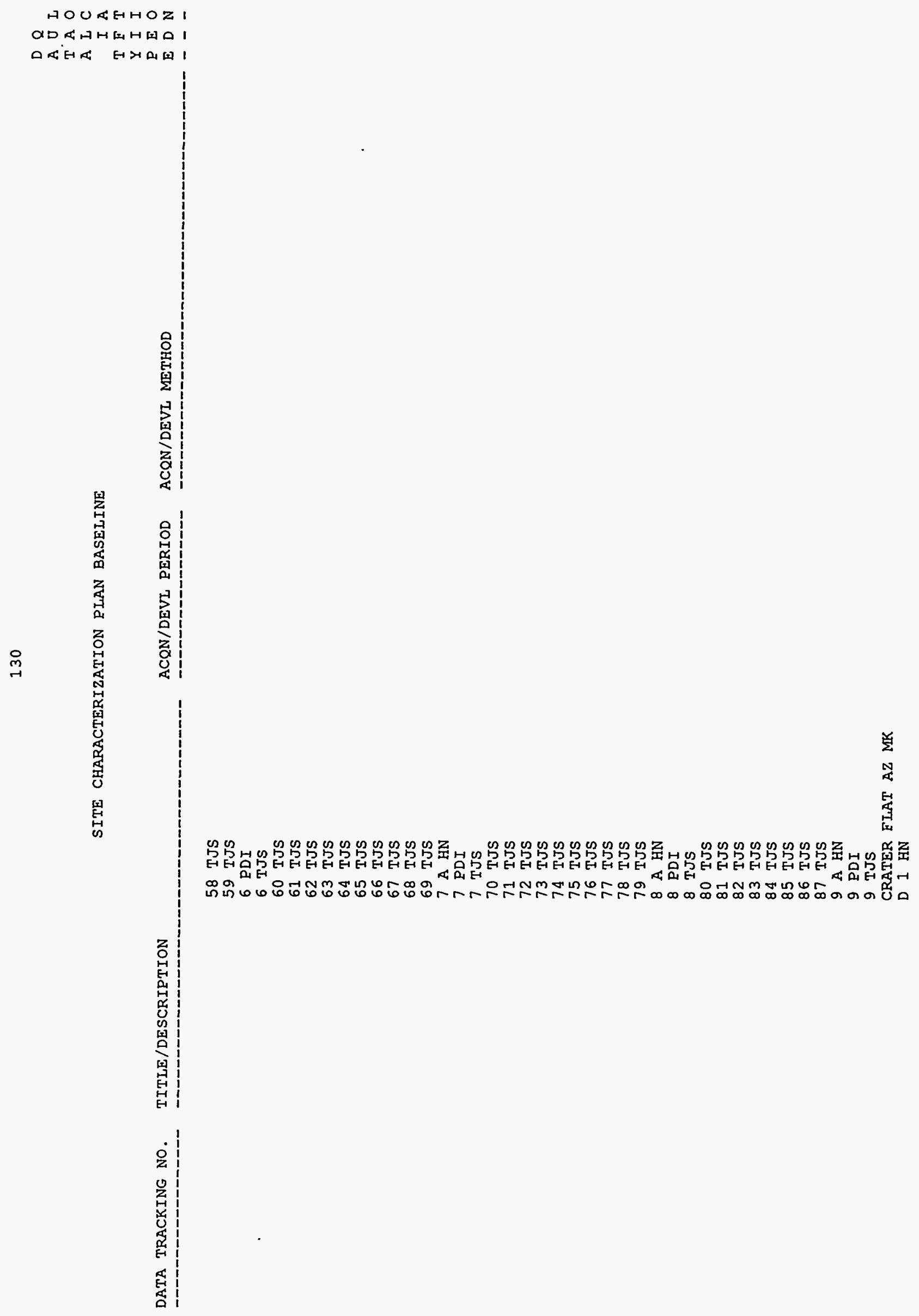


SITE CHARACTERIZATION PLAN BASELINE

\section{DATA TRACKING NO. TITLE/DESCRIPTION}
$\begin{array}{lll}D & 10 & \mathrm{HN} \\ \mathrm{D} & 11 & \mathrm{HN}\end{array}$
D 2 HN
D $3 \mathrm{HN}$
$\begin{array}{lll}D & 4 & \mathrm{HN} \\ \mathrm{D} & 5 & \mathrm{HN}\end{array}$
$\begin{array}{lll}D & 5 & \mathrm{HN} \\ \mathrm{D} & 6 & \mathrm{HN}\end{array}$
D $7 \mathrm{HN}$
D 8 HN
D 9 HN
DA HN
G 408
H 408
MILE
P 333
$\begin{array}{ll}\text { P } & 333 \\ \text { R } 333\end{array}$
S 16 RESET

Activity - 8.3.1.17.4.10.2

**GS950331174102.001 GLOBAI POSITIONING SYSTEM PROFILE: YOCCA MOUNTAIN TO SIERRA NEVADA, J.C. SAVAGE

$11 / 01 / 94-11 / 30 / 94$ ECTED IN A Y T RO, GEODETIC TRILATERATION AND GLOBAI POSITIONING SYSTEM (GPS) SURVEYS.

\begin{tabular}{|c|c|}
\hline ACQN/DEVI IOCATION & $\begin{array}{l}\text { 13D } 15761948 \\
\text { 1RDI } \\
6813 \text { BB10 } 1905 \\
\text { B80 } 22531907 \\
\text { BM } 251905 \\
\text { BP ARIES } 1977 \\
\text { CERRO GORDO } 1934 \\
\text { CLAIM } 1991 \\
\text { F23 } 1933 \\
\text { FORK OSGS } \\
\text { G } 1651933 \\
\text { GGBV } 5113834 \\
\text { GOO5 } \\
\text { HOLDE } 1949 \\
\text { JOSHOA RIDGE } \\
\text { KENNEDY MEADOWS } 3187 \\
\text { LI66 } 1933 \\
\text { M1377 } 1984 \\
\text { MON } 93 \text { OFFSET } 1899 \quad 1949\end{array}$ \\
\hline
\end{tabular}


SITE CHARACTERIZATION PLAN BASELINE

DATA TRACKING NO. TITLE/DESCRIPTION

ACQN/DEVL PERIOD

ACQN/DEVL METHOD

P16 RESET 1978

P166 54451933

SHOSHONE 19XX

STOVEPIPE WELLS 1949

T19SR40ER41ES36S31S1S6T20 1941

$\times 13721983$

Activity - 8.3.1.17.4.10.3

**GS920931174103.002 GEODETIC LEVELING DATA USED TO DEFINE HISTORICAL HEIGHT CHANGES BETWEEN TONOPAH JONCTION AND LAS VEGAS, NEVADA BY THOMAS D. GILMORE

ACQN/DEVL LOCATION : OSGS, MENLO PARK, CA

Activity - 8.3.1.19.2.1

* LL940909304242.007 GAS PERMEABILITY AS A FUNCTION OF TEMPERATORE. VARIATION OF GAS PERMEABILITY DOE TO STEAM FLOW.

$09 / 27 / 90-06 / 11 / 91$

$$
\begin{aligned}
& \text { DONE ONDER PREVIOUS ILNL-YMP ACTIVITY } \\
& \text { B-20-1. ACTIVITY IS NOW GH-O1.1. } \\
& \text { PREVIOOS WBS WAS } 1.2 .2 .2 \text { OSED STEADY } \\
& \text { STATE FLOW-THROOGH METHOD TO MEASURE }
\end{aligned}
$$
PERMEABILITY.

COMPARISONS OF REPEATED GEODETIC IEVELING

ALONG THE SURVEY ROOTE. STANDARD OSGS

ATONG DOLOGY. COMPOTER RROGRAMS PROCESSED

DIGITAL FIIES FROM THE NATIONAI GEODETI

SURVEY AND HANDWRITTEN SUMMARY BOORS FROM

.S. GEOLOGICAI SURVEY NATIONAL MAPPING

DIVISION ARCHIVES.

ACON/DEVL LOCATION : ILNL
A $\mathrm{C}$ 
SITE CHARACTERIZATION PLAN BASELINE

DATA TRACKING NO.

TITLE/DESCRIPTION

ACON/DEVI PERIOD

ACON/DEVT METHOD

$01 / 10 / 95-04 / 04 / 95$

*LL950404104242.014 FRACTURE HEALING EXPERIMENT DATA

DESCRIBES PERMEABIIITY EXPERIMENTS OF TOPOPAH SPRING TOFF.

ACQN/DEVI LOCATION : IAAWRENCE IIVERMORE NATIONAL LABORATORY

*IL950404504242.011 POROSITY DATA OF TOPOPAH SPRING TOFF.

$07 / 01 / 92-12 / 01 / 94$

DONE ONDER IINL-YMP ACTIVITY PIAN GH-01.1. D N P TWELVE SAMPLES WERE SOBCORED AND COT INTO DISKS. AVERAGE POROSITY WAS DETERMINED BY SUBTRACTING THE DRY DENSITY FROM THE SATORATED DENSITY AND DIVIDING BY THE WATER DENSITY.

ACQN/DEVL LOCATION : LAWRENCE LIVERMORE NATIONAL IABORATORY

*LL950406104242.016 PERMEABILITY OF FRACTURED TUFF AS A FONCTION OF TEMPERATURE AND CONFINING PRESSURE.

$08 / 01 / 92-10 / 01 / 94$

DONE UNDER LLNL-YMP ACTIVITY PLAN GH-01.1. D N P SAMPLE WAS PLACED IN A PRESSURE VESSEL HEATED EXTERNALIY. CONEINING PRESSURE WAS MAINTAINED. SAMPLE WAS KEPT SATURATED AT ALL TIMES.

ACQN/DEVL IOCATION : IAAWRENCE IIVERMORE NATIONAL IABORATORY

*LL950406204242.015 EFFECT OF ROCK-WATER INTERACTION ON

$03 / 22 / 94-04 / 04 / 95$ PERMEABILITY

ACQN/DEVL LOCATION : LAWRENCE LIVERMORE NATIONAI LABORATORY
DONE DNDER ILNL-YMP ACTIVITY PIAN GH-01.1 A N P THE FRACTORED TOPOPAH SPRING TOFF IS SATORATED WITH J-13 WATER.
DONE UNDER ILNL-YMP ACTIVITY GH-01.1. A

CYLINDRICAL SAMPIE OF TORORAH

WAS MACHINED FROM CORE SECTIONS.

ORIGINAL CORE CONTAINED AN INTACT

LONGITODINAI NATORAI FRACTORE WHICH WAS PULLED OREN WHEN THE SAMPIE WAS MACHINED. PERMEABILITY WAS MEASURED AS FUNCTIONS O TAMPIR WAS SATORATE 
Activity - 8.3.1.19.2.2

*IL950404404242.010 SPREAD SHEETS OF ELECTRICAL PROPERTIES OF TOPOPAH SPRING TUFF AS A FUNCTION OF FREQUENCY, SATURATION AND TEMPERATORE.

ACQN/DEVL IOCATION : LAWRENCE IIVERMORE NATIONAL LABORATORY

\section{*LI950404604242.012 PERMEABILITY AS A FONCTION OF} TEMPERATURE; MATRIC POTENTIAL AS A

$07 / 01 / 92-12 / 01 / 94$ FUNCTION OF TEMPERATURE AND SATURATION AND CHEMICAL ANALYSIS OF TOPORAH SPRING

$07 / 01 / 92-12 / 01 / 94$

DONE UNDER LLNL-YMP ACTIVITY PLAN MEASOREMENTS WERE MADE AT VARIOUS TEMPERATORES AND SATURATION. ELECTRICAI RESISTIVITY AND DIELECTRIC PERMITTIVITY WERE MEASURED AS A FONCTION OF FREQOENCY. WATER FROM J-13 WELL WAS ADDED IN SMALL AMOONTS TO A DRY SAMPIE AND AILOWED TO DISTRIBOTE THROUGHOOT THE SAMPLE.

ACQN/DEVI LOCATION : LAWRENCE LIVERMORE NATIONAL LABORATORY

Activity - 8.3.1.19.4.1

**LL950103004244.004 A PROGRESS REPORT FOR THE LARGE BLOCK

$12 / 01 / 93-07 / 30 / 94$

THERMAL-MECHANICAL-HYDROLOGICAL-CHEMICAI PROCESSES

ACON/DEVL LOCATION : FRAN RIDGE LARGE BLOCK TEST

DONE ONDER LINL-YMP ACTIVITY PLAN GH-01.1. D N P A SAMPLE CONTAINING A SINGLE OPEN FRACTUR WAS OBTAINED, SUBCORED, AND MACHINED. NO ADDITIONAI VISIBLE FRACTORES WERE CREATED

THIS REPORT CONTAINS POROSITY MEASURED BY A MERCORY POROSIMETER. SATURATION AND DRY METHODS WERE OSED. MEASURING OF MOISTURE CONTENT OSED NEUTRON LOGGING.

PERMEABILITY MEASURES OSED THE AIR INJECTION STEADY-STATE FLOW METHOD. 
DATA TRACKING NO.

* LL940804051021.000 THE INTRINSIC DISSOLOTION KINETICS OF OO2 WERE STODIED ONDER A WIDE RANGE OF CONTROLLED ALKALINE CONDITIONS BETWEEN 25 AND 75 DEGREES, DSING THE SINGLE-PASS FLOW-THRODGH METHOD

ACQN/DEVL IOCATION : ILNL, IIVERMORE, CA

\section{**IL941015651021.002 INFORMATION CONTAINS EXPERIMENTALLY} DETERMINED DISSOIOTION RATE OF SOLID SINGIE CRYSTAL DO2 AS A FONCTION OF THE PARTIAI PRESSORE OF OXYGEN IN THE VAPOR PHASE ABOVE THE BOFFER SOLUTION AT ROOM TEMPERATORE.

ACQN/DEVL LOCATION : ILNL
$11 / 21 / 91-04 / 08 / 94$ SIP-WF-01. TO TEST FOR NONLINEAR EFEECTS OF FOUR VARIABLES ON THE DISSOLOTION RATE VARIABLES, A STATISTICAI EXPERIMENTAL DESIGN APPROACH WAS USED TO SELECT THE EXPERIMENTS TO BE PERFORMED AND TO REDUCE THE NOMBER OF REQOIRED EXPERIMENTS. A SET OF EXPERTMENTS WERE SEIECTED TO EXAMINE SYSTEMATICAILY THE EEFECTS OF TEMPERATURE DISSOLVED OXYGEN AND CARBONA CONCENTRATIONS ON 002 DISSOLOTION.

\section{$04 / 21 / 93-02 / 09 / 94$}

DONE ONDER LLNL-YMP ACTIVITY D-20-49.1, ACTIVITY D-20-53A, AND SIP-WE-01. TO TEST FOR NONLINEAR EFFECTS OF FOUR VARIABIES ON THE DISSOLOTION RATE AND ANY INTERACTION EEFECTS BETWEEN THE VARIABIES, A STATISTICAI EXPERIMENTAL DESIGN APPROACH WAS USED TO SELECT THE EXPERTMENTS TO BE PERFORMED AND TO REDUCE THE NUMBER OF REOOIRED EXPERIMENTS, EXPERIMENTS WERE SELECTED TO EXAMINE SYSTEMATICALIY THE EFFECTS OF DISSOLVED OXYGEN CONCENTRATION ON SINGLE-CRYSTAL 002 DISSOLOTION RATES. AND ANY INTERACTION EFFECTS BETWEEN THE 
SITE CHARACTERIZATION PLAN BASELINE

DATA TRACKING NO.

TITLE/DESCRIPTION

*IL950404251021.008 DATA DOCUMENT EXPERIMENTS AND

INFORMATION FOR TEST PLAN \#2 ON OO
DISSOLUTION STUDIES (O308 AND UO3-H20).

ACQN/DEVL LOCATION : LAWRENCE IIVERMORE NATIONAI LABORATORY

*LL950404351021.009 INEORMATION CONTAINS EXPERIMENTALLY DETERMINED DISSOLOTION RATE OE SOIID SINGLE CRYSTAL UO2 AS A FUNCTION OF THE PARTIAI PRESSURE OF OXYGEN IN THE VAPOR PHASE ABOVE THE BUFFER SOLOTION AT ROOM TEMPERATORE.

$03 / 01 / 94-03 / 01 / 95$ DONE UNDER LLNL-YMP ACTIVITY D-20-49.1, ACTIVITY D-20-53A, AND SIP-WE-01. TO TEST EOR NONLINEAR EFFECTS OF FOOR VARIABLES ON THE DISSOLOTION RATE AND ANY INTERACTION EFFECTS BETWEEN THE VARIABLES, A

STATISTICAI EXPERIMENTAL DESIGN APPROACH WAS OSED TO SEIECT THE EXPERIMENTS TO BE PERFORMED AND TO REDOCE THE NUMBER OF REODIRED EXPERTMENTS REQUIRED EXPERIMENIS EFFECTS OF DISSOLVED OXYGEN CONCENTRATIO ON SINGLE-CRYSTAL DO2 DISSOLUTION RATES.

ACQN/DEVL LOCATION : LAWRENCE IIVERMORE NATIONAL IABORATORY
$10 / 01 / 90-09 / 30 / 91$ RATE OF GRAIN VOIUME FRONT PROPAGATION DO(2) TO $\sigma(4) O(9)$ AND ACTIVATION ENERGY FOR THIS RATE.

ACQN/DEVL LOCATION : PNL 


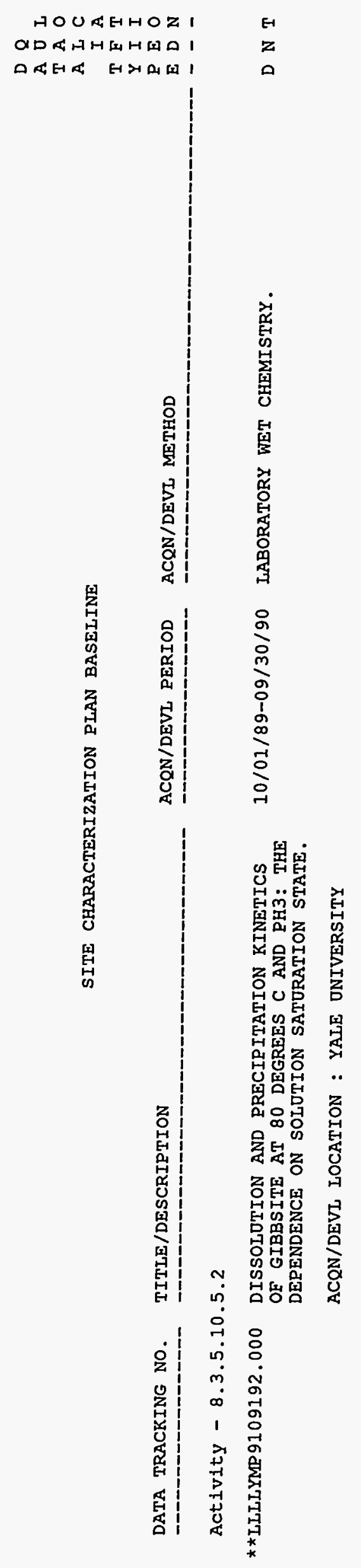


SOCIOECONOMIC RIAN

DATA TRACKING NO.

TITLE/DESCRIPTION

**TM00121361T1EC.001 YOCCA MOUNTAIN SITE CHARACTERIZATION PROJECT SOCIOECONOMIC MONITORING PROGRAM QDARTERLY EMPLOYMENT DATA REPORT, OCTOBER 1994 THROUGH DECEMBER 1994
ACQN/DEVL LOCATION : M\&O/SAIC

$* * 1900121361911$
ACON/DEVI PERIOD

ACQN/DEVL METHOD

10/01/94-12/31/94 MONITORING OF YUCCA MOUNTAIN SITE CHARACTERIZATION PROJECT CHARACTERISTICS AS DECSRIBED IN REVISION $O$ OF THE SOCIOECONOMIC PLAN

D $Q$

A U I

T A O

A I C

A $Y T$ 
DATA TRACKING NO. TITLE/DESCRIPTION

**M09212RIB00017.003 RIB ITEM\#17/REV3: SOIL AND ROCK CHARACTERISTICS: ROCK CHARACTERISTICS CHARACIERISTICS: ROCK CHARACTERISTICS: ROCK THERMAT

ACQN/DEVI LOCATION : SNL

\section{ACQN/DEVL PERIOD}

ACON/DEVT METHOD

ACQN/DEVL PERIOD ACQN/DEVL METHOD E D N

12/14/92-12/14/92 THERMAI CONDUCTIVITY WAS MEASURED I

SAMPIES FROM SEVERA DRTITHOITS AND

THERMAT/MECHANTCAI STRATIGRAPHIC ONITS AT

YOCCA MODNTAIN THE TRANS IENT-IINE-SOURCE

TECHNIQOE WAS OSED FOR THESE MEASUREMENTS

AN EIECTRIC CORRENT WAS APRLIED TO AN

AXIAL HEATER WITHIN A THICK-WALLED

CYLINDRICAL SAMPLE, AND THE

TEMPERATORE/TIME RESPONSE WAS MONITORED.

MEASOREMENTS OF THIS TYPE WERE MADE AT

DIFFERENT TEMPERATORES FOR EACH SAMPIE. AN

DIETERTCAT MT

THERMAI CONDUCTIVITY DATA. 


\section{APPENDIX A}

SITE CHARACTERIZATION PROGRAM BASELINE ACTIVITY NUMBERS AND NAMES

8.3.1.2.1.1.1 Precipitation and meteorological monitoring

8.3.1.2.1.2.1 Surface-water runoff monitoring

8.3.1.2.1.2.2 Transport of debris by severe runoff

8.3.1.2.1.3.1 Assessment of the regional hydrogeologic data needs in the saturated zones

8.3.1.2.1.3.2 Regional potentiometric-level distribution and hydrogeologic framework studies

8.3.1.2.1.3.3 Fortymile wash recharge study

8.3.1.2.1.3.4 Evapotranspiration studies

8.3.1.2.1.4.1 Conceptualization of regional hydrologic flow models

8.3.1.2.1.4.2 Subregional two-dimensional area hydrologic modeling

8.3.1.2.1.4.4 Regional three-dimensional areal hydrologic modeling

8.3.1.2.2.1 Characterization of unsaturated-zone infiltration

8.3.1.2.2.1.1 Characterization of hydrological properties of surficial materials

8.3.1.2.2.1.2 Evaluation of natural infiltration

8.3.1.2.2.1.3 Evaluation of artificial infiltration

8.3.1.2.2.2.1 Chloride and chlorine-36 measurements of percolation at Yucca Mountain

8.3.1.2.2.3.1 Matrix hydrologic properties testing

8.3.1.2.2.3.2 Site vertical borehole studies

8.3.1.2.2.4.2 Percolation tests in the Exploratory studies Facility 
8.3.1.2.2.4.4 Radial borehole tests in the Exploratory studies Facility

8.3.1.2.2.4.7 Perched-water test in the Exploratory studies Facility

8.3.1.2.2.4.8 Hydrochemistry tests in the Exploratory studies Facility

8.3.1.2.2.4.9 Multipurpose-borehole testing

8.3.1.2.2.6.1 Gaseous-phase circulation study

8.3.1.2.2.7.1 Gaseous - phase chemical investigations

8.3.1.2.2.7.2 Aqueous-phase chemical investigations

8.3.1.2.2.8.1 Development of conceptual and numerical models of fluid flow in unsaturated, fractured rock

8.3.1.2.2.9.1 Conceptualization of the unsaturated-zone hydrogeologic system

8.3.1.2.2.9.3 Simulation of the natural hydrogeologic system

8.3.1.2.3.1.2 Site potentiometric-level evaluation

8.3.1.2.3.1.3 Analysis of single- and multiple-well hydraulic-stress tests

8.3.1.2.3.1.4 Multiple-well interference testing

8.3.1.2.3.1.6 well testing with conservative tracers throughout the site

8.3.1.2.3.1.7 Testing of the C-hole sites with conservative tracers

8.3.1.2.3.2.1 Assessment of saturated-zone hydrochemical data availability and needs

8.3.1.2.3.2.2 Hydrochemical characterization of water in the upper part of the saturated zone

8.3.1.2.3.2.3 Regional hydrochemical tests and analyses 
8.3.1.2.3.3.1 Conceptualization of saturated-zone flow models within the boundaries of the accessible environment

8.3.1.2.3.3.2 Development of fracture network model

8.3.1.2.3.3.3 Calculation of flow paths, fluxes, and velocities within the saturated-zone to the accessible environment

8.3.1.3.1.1 Ground-water chemistry model

8.3.1.3.2.1 Mineralogy, petrology, and chemistry of transport pathways

8.3.1.3.2.1.1 Petrologic stratigraphy of the Topopah spring Member

8.3.1.3.2.1.2 Mineral distributions between the host rock and the accessible environment

8.3.1.3.2.1.3 Fracture mineralogy

8.3.1.3.2.2.1 History of mineralogic and geochemical alteration of Yucca Mountain

8.3.1.3.2.2.2 Smectite, zeolite, manganese minerals, glass dehydration, and transformation

8.3.1.3.4.1 Batch sorption studies

8.3.1.3.4.1.1 Batch sorption measurements as a function of solid phase composition

8.3.1.3.4.1.2 Sorption as a function of sorbing element concentrations (isotherms)

8.3.1.3.4.1.3 Sorption as a function of ground-water composition

8.3.1.3.4.2 Biological sorption and transport

8.3.1.3.5.1.1 Solubility measurements

8.3.1.3.5.1.2 speciation measurements

8.3.1.3.6.1.1 Crushed tuff column experiments

8.3.1.3.6.1.2 Mass transfer kinetics 

8.3.1.3.6.2.1 Uptake of radionuclides on rock beakers in a saturated system
$8 \cdot 3 \cdot 1 \cdot 3 \cdot 6 \cdot 2 \cdot 2$
Diffusion through a saturated tuff slab
$8 \cdot 3 \cdot 1 \cdot 4 \cdot 1 \cdot 2$
Integration of geophysical activities
$8 \cdot 3 \cdot 1 \cdot 4 \cdot 2 \cdot 1$
Characterization of the vertical and lateral
distribution of stratigraphic units within the site area
$8 \cdot 3 \cdot 1 \cdot 4 \cdot 2 \cdot 1 \cdot 1$
Surface and subsurface stratigraphic studies of
the host rock and surrounding units
8.3.1.4.2.1.2 Surface-based geophysical surveys
8.3.1.4.2.1.3 Borehole geophysical surveys
8.3.1.4.2.1.4 Petrophysical properties testing
8.3.1.4.2.1.5 Magnetic properties and stratigraphic correlations
8.3.1.4.2.1.6 Integration of geophysical activities
8.3.1.4.2.2 Characterization of the structural features within the site area
8.3.1.4.2.2.1 Geologic mapping of zonal features in the Paintbrush Tuff
8.3.1.4.2.2.2 Surface-fracture network studies
8.3.1.4.2.2.3 Borehole evaluation of faults and fractures
8.3.1.4.2.2.4 Geologic mapping of the Exploratory studies Facility
8.3.1.4.2.2.5 Seismic tomography/vertical seismic profiling
8.3.1.4.2.3.1 Development of a three-dimensional geologic model of the site area 8.3.1.4.3.1 $\begin{aligned} & \text { Systematic acquisition of site-specific subsurface } \\ & \text { information }\end{aligned}$
8.3.1.4.3.1.1 Systematic drilling program
8.3.1.5.1.1.1 Synoptic characterization of regional climate 


\subsection{1 Paleontologic analyses}

8.3.1.5.1.2.2 Analysis of the stratigraphy-sedimentology of marsh lacustrine, and playa deposits

8.3.1.5.1.3.1 Analysis of pack rat middens

8.3.1.5.1.3.3 Determination of vegetation-climate relationships

8.3.1.5.1.4.1 Modeling of soil properties in the Yucca Mountain region

8.3.1.5.1.4.2 Surficial deposits mapping of the Yucca Mountain area

8.3.1.5.1.4.3 Eolian history of the Yucca Mountain region

8.3.1.5.1.5.1 Paleoclimate-paleoenvironmental synthesis

8.3.1.5.2.1.1 Regional paleoflood evaluation

8.3.1.5.2.1.2 Quaternary unsaturated zone hydrochemical analysis

8.3.1.5.2.1.3 Evaluation of past discharge areas

8.3.1.5.2.1.4 Analog recharge studies

8.3.1.5.2.1.5 Studies of calcite and opaline silica vein deposits

8.3.1.6.1.1 Distribution and characteristics of present and past erosion

8.3.1.6.1.1.1 Development of a geomorphic map of Yucca Mountain

8.3.1.6.1.1.2 Analysis of the downcutting history of Fortymile Wash and its tributaries

8.3.1.6.1.1.3 An analysis of hillslope erosion at Yucca Mountain

8.3.1.6.2.1.1 Synthesis and data evaluation of impact of future climatic conditions on locations and rates of erosion

8.3.1.6.3.1.1 Synthesis and data evaluation of the impact of future uplift or subsidence and faulting on erosion at Yucca Mountain and vicinity 
8.3.1.8.1.1.2 Evaluation of the structural controls of basaltic volcanic events

8.3.1.8.1.1.3 Presence of magma bodies in the vicinity of the site

8.3.1.8.1.1.4 Probability calculations and assessment

8.3.1.8.1.2.1 Eruptive effects

8.3.1.8.2.1.1 Analysis of waste package rupture due to tectonic processes and events

8.3.1.8.3.2.2 Assessment of the effects of igneous intrusions on water-table elevations

8.3.1.8.3.2.5 Effects of faulting on water-table elevation

8.3.1.8.5.1.2 Geochronology studies

8.3.1.8.5.1.3 Field geologic studies

8.3.1.8.5.1.4 Geochemistry of scoria sequences

8.3.1.8.5.1.5 Geochemical cycles of basaltic volcanic fields

8.3.1.8.5.2 Characterization of igneous intrusive features

8.3.1.8.5.2.1 Evaluation of depth of curie temperature isotherm

8.3.1.8.5.2.3 Heat flow at Yucca Mountain and evaluation of regional ambient heat flow and local heat flow anomalies

8.3.1.8.5.2 Characterization of igneous intrusive features

8.3.1.8.5.2.1 Evaluation of depth of curie temperature isotherm

8.3.1.8.5.2.3 Heat flow at Yucca Mountain and evaluation of regional ambient heat flow and local heat flow anomalies

8.3.1.9.2.1 Natural resource assessment of Yucca Mountain, Nye County, Nevada

8.3.1.9.2.1.1 Geochemical assessment of Yucca Mountain in relation to the potential for mineralization

$$
\text { A-6 }
$$


8.1.3.9.2.1.3 Assessment of the potential for geothermal energy at Yucca Mountain, Nevada

8.3.1.9.2.1.4 Assessment of hydrocarbon resources at and near the site

8.3.1.9.2.2.1 Projected trends in local and regional groundwater development, and estimated withdrawal rates in southern Nevada, proximal to Yucca Mountain

8.3.1.12.2.1.1 Site meteorological monitoring program

8.3.1.14.2.1.1 Site reconnaissance

8.3.1.14.2.1.2 Preliminary and detailed exploration

8.3.1.14.2.1.3 Detailed exploration

8.3.1.14.2.2 Laboratory tests and material property measurements

8.3.1.14.2.2.1 Physical property and index laboratory tests

8.3.1.14.2.2.2 Mechanical and dynamic laboratory property tests

8.3.1.14.2.3 Field tests and characterization measurements

8.3.1.14.2.3.1 Physical property field tests and characterization measurements

8.3.1.14.2.3.2 Mechanical property field tests

8.3.1.14.2.3.3 Geophysical field measurements

8.3.1.15.1.1 Laboratory thermal properties

8.3.1.15.1.1.1 Density and porosity characterization

8.3.1.15.1.1.2 Volumetric heat capacity characterization

8.3.1.15.1.1.3 Thermal conductivity characterization

8.3.1.15.1.2.1 Thermal expansion characterization

8.3.1.15.1.3 Laboratory determination of mechanical properties of intact rock 
8.3.1.15.1.3.1 Compressive mechanical properties of intact rock at baseline experiment conditions

8.3.1.15.1.3.2 Effects of variable environmental conditions on mechanical properties

8.3.1.15.1.4 Laboratory determination of the mechanical properties of fractures

8.3.1.15.1.4.1 Mechanical properties of fractures at baseline experiment conditions

8.3.1.15.1.4.2 Effects of variable environmental conditions on mechanical properties of fractures

8.3.1.15.1.7.1 Plate loading tests

8.3.1.15.1.8.1 Evaluation of mining methods

8.3.1.15.1.8.2 Monitoring of ground-support systems

8.3.1.15.2.1.2 Overcore stress experiments in the exploratory studies facility

8.3.1.15.2.2.1 Surface-based evaluation of ambient thermal conditions

8.3.1.16.1.1.1 Site flood and debris hazards studies

8.3.1.16.2.1.4 Identification and evaluation of potential effects of repository related withdrawals on the local

flow system at Yucca Mountain, Nevada

8.3.1.17.2.1.2 Assess the potential for displacement on faults that intersect underground facilities

8.3.1.17.3.1 Relevant earthquake sources

8.3.1.17.3.1.1 Identify relevant earthquake sources

8.3.1.17.3.1.2 Characterize 10,000-yr cumulative slip earthquakes for relevant seismogenic sources

8.3.1.17.3.3 Ground motion from regional earthquake and underground nuclear explosions

8.3.1.17.3.3.2 select or develop empirical models for ground motion from underground nuclear explosions 
8.3.1.17.3.4.1 Determine site effects from ground-motion recordings

8.3.1.17.3.5 Ground motion at the site from controlling seismic events

8.3.1.17.3.5.1 Identify controlling seismic events

8.3.1.17.3.5.2 Characterize ground motion from the controlling seismic events

8.3.1.17.3.6 Probabilistic seismic hazards analyses

8.3.1.17.3.6.2 Evaluate ground motion probabilities

8.3.1.17.4.1 Historical and current seismicity

8.3.1.17.4.1.1 Compile historical earthquake record

8.3.1.17.4.1.2 Monitor current seismicity

8.3.1.17.4.1.3 Evaluate potential for induced seismicity at the site

8.3.1.17.4.2 Location and recency of faulting near prospective surface facilities

8.3.1.17.4.2.1 Identify appropriate trench locations in Midway Valley

8.3.1.17.4.2.2 Conduct exploratory trenching in Midway valley

8.3.1.17.4.3 Quaternary faulting within $100 \mathrm{~km}$ of Yucca

Mountain, including the walker Lane

8.3.1.17.4.3.1 Conduct and evaluate deep geophysical surveys in an east-west transect crossing the Furnace Creek fault zone, Yucca Mountain, and the Walker Lane

8.3.1.17.4.3.2 Evaluate Quaternary faults within $100 \mathrm{~km}$ of Yucca Mountain

8.3.1.17.4.3.4 Evaluate the Bare Mountain fault zone

8.3.1.17.4.3.5 Evaluate structural domains and characterize the Yucca Mountain region with respect to regional patterns of faults and fractures 
8.3.1.17.4.4 Quaternary faulting proximal to the site within northeast-trending fault zones

8.3.1.17.4.4.1 Evaluate the Rock Valley fault system

8.3.1.17.4.5.1 Evaluate the significance of the Miocene-Paleozoic contact in the Calico Hills area to detachment faulting within the site area

8.3.1.17.4.5.2 Evaluate postulated detachment faults in the Beatty-Bare Mountain area

8.3.1.17.4.6 Quaternary faulting within the site area

8.3.1.17.4.6.1 Evaluate Quaternary geology and potential Quaternary faults at Yucca Mountain

8.3.1.17.4.6.2 Evaluate age and recurrence of movement on suspected and known Quaternary faults

8.3.1.17.4.7 Subsurface geometry and concealed extensions of Quaternary faults at Yucca Mountain

8.3.1.17.4.7.1 Evaluate intermediate depth $(2$ to $3 \mathrm{~km}$ ) reflection and refraction methods and plan potential

application of these methods within the site area

8.3.1.17.4.7.2 Detailed gravity survey of the site area

8.3.1.17.4.7.3 Detailed aeromagnetic survey of the site area

8.3.1.17.4.7.4 Detailed ground magnetic survey of specific features within the site area

8.3.1.17.4.7.5 Evaluate surface geoelectric methods and plan potential application of these methods within the site area

8.3.1.17.4.7.8 Evaluate shallow seismic reflection (mini-sosie) methods and, if appropriate, conduct surveys of selected structures at and proximal to the site area

8.3.1.17.4.8. Stress field within and proximal to the site area 8.3.1.17.4.8.1 Evaluate present stress field within site area 
8.3.1.17.4.8.2 Evaluate and test shallow borehole hydrofrac and triaxial strain recovery methods for the determination of in situ stress and, if appropriate, plan potential application of these methods within and proximal to the site

8.3.1.17.4.9 Tectonic geomorphology of the Yucca Mountain region

8.3.1.17.4.9.1 Evaluate age and extent of tectonically stable areas at and near Yucca Mountain

8.3.1.17.4.10.1 Relevel base-station network, Yucca Mountain and vicinity

8.3.1.17.4.10.2 Survey selected base stations, Yucca Mountain and vicinity, using global positioning satellite.

8.3.1.17.4.10.3 Analyze existing releveling data, Yucca Mountain and vicinity

8.3.1.17.4.11 Characterization of regional lateral crustal movement

8.3.1.17.4.12 Tectonic models and synthesis

8.3.1.17.4.12.1 Evaluate tectonic processes and tectonic stability at the site

8.3.1.19.1.1 Rock-water interactions at elevated temperatures

8.3.1.19.1.4 Dissolution of phases in the waste package environment

8.3.1.19.2.1 Single-phase fluid system properties

8.3.1.19.2.2 Two-phase fluid system properties

8.3.1.19.4.1 Repository horizon near-field hydrologic properties

8.3.1.19.5.1 Effect of grout, concrete, and other repository materials on water composition

8.3.2.4.1.1 Design activity to verify access and drift usability

8.3.3.2.2.3 In situ testing of seal components 
8.3.5.4.1.1 Refinement of site data parameters required for Issue 2.2

8.3.5.9.2.4 Degration modes affecting ceramic-metal, bimetallic/single metal, or coatings and filler systems

8.3.5.9.1.2 Integrate design and materials information (alternate barriers investigation)

8.3.5.10.2.1 Characterization of the spent fuel waste form

8.3.5.10.2.2 Characterization of the glass waste form

8.3.5.10.3.2 Develop geochemical speciation and reaction model

8.3.5.10.5.1 Determine radionuclide transport parameters

8.3.5.10.5.2 Radionuclide transport modeling in the near-field waste package environment

8.3.5.12.1.1 Application of results

8.3.5.12.2.1 Model development

8.3.5.12.2.1.1 Development of a theoretical framework for calculational models

8.3.5.12.2.2 Verification and validation 


\section{APPENDIX B}

\section{GENISES ADDITIONS: 3rd QUARTER, FY 1995}

DATA TRACKING NO, DATA ITEM DESCRIPTION

GS910508315213.001

GS910808312212.001

GS911008314213.009

GS911108312313.009

GS911108315213.004

GS911208315213.005
PHYSICAL PROPERTY DATA FROM PLAYA SOIL SAMPLES COLLECTED 1/4/91 TO 1/10/91 AT JORNADA, FLAT, OLD COE, DRY (ON FT. BLISS RANGE), ISAACK, PLAYAS AND GRONTON LAKES, AND WHITE SANDS IN NM; BROADWELL, DANBY, DRY (NEAR PANAMINT SPRING), DRY (ON 29 PALMS BASE), FORD DRY, FORD, HARPER, HAYFIELD, AND MIRROR LAKES, AND BADWATER IN CA; PETERS PLAYA AND STEWART VALLEY IN NV; 1/24/91 TO $1 / 26 / 91$

GEOHYDROLOGIC DATA COLLECTED FROM SHALLOW NEUTRON-ACCESS BOREHOLES AND RESULTANT PRELIMINARY GEOHYDROLOGIC EVALUATIONS, YUCCA MOUNTAIN AREA, NYE COUNTY, NEVADA

RESULTS OF ROCK PROPERTY MEASUREMENTS MADE ON CORE SAMPLES FROM YUCCA MOUNTAIN BOREHOLES, NTS, NEVADA. PART 1 . BOREHOLES UE25A-4, -5, -6, AND -7. PART 2. BOREHOLE UE25P\#1

GEOHYDROLOGY OF ROCKS PENETRATED BY TEST WELL USW H-6, YUCCA MOUNTAIN, NYE COUNTY, NEVADA

LAB ANALYSIS RESULTS AND PHYSICAL PROPERTY CHARACTERISTICS FROM PLAYA SOIL SAMPLES TAKEN FROM VARIOUS PLAYAS IN CALIFORNIA AND NEVADA, 10/17/91 TO 10/26/91. NEVADA LOCATIONS: BIG SMOKEY VALLEY, BONNIE CLAIR, COAL VALLEY, STEWART VALLEY, PAHRUMP VALLEY, PETER'S AND LIDA JUNCTION SOUTH PLAYAS, ALKALI FLAT, FRENCH LAKE, MUD LAKE, AMARGOSA FLAT, RALSTON VALLEY, SAND SPRING

LAB ANALYSIS RESULTS AND PHYSICAL PROPERTY CHARACTERISTICS OF SURFICIAL SOIL SAMPLES TAKEN FROM WILCOX DRY PLAYA, AZ, AND SOUTH ALKALI FLAT, NM, 11/12/91 - 11/14/91 
GS920708312111.005

GS920931174103.002

GS921008312312.021

GS921108312331.001

GS930108315213.004

GS930208315213.008

GS930308315213.013

GS930983117432.014

GS931008312261.002

GS931008312261.003

GS931208314221.012
PRECIPITATION DEPTH, IN INCHES, COLLECTED USING A NETWORK OF NON-AUTOMATED, COLLECTORTYPE PLASTIC GAUGES. MEASUREMENTS WERE TAKEN AFTER EACH MAJOR PRECIPITATION EVENT AND TOTALLED FOR EACH MONTH. DATA COLLECTED FROM 01/01/90 TO 09/30/91.

GEODETIC LEVELING DATA USED TO DEFINE HISTORICAL HEIGHT CHANGES BETWEEN TONOPAH JUNCTION AND LAS VEGAS, NEVADA

WATER LEVELS IN CONTINUOUSLY MONITORED WELLS IN THE YUCCA MOUNTAIN AREA, NEVADA, 1989

REVISED POTENTIOMETRIC SURFACE MAP OF YUCCA MOUNTAIN AND VICINITY, NEVADA

URANIUM ISOTOPIC ANALYSES OF GROUNDWATERS FROM SW NEVADA - SE CALIFORNIA

VEGETATION TRANSECT DATA FOR AMARGOSA VALLEY INCLUDING VEGETATION SPECIES NAMES, COVERAGES, LENGTH, HEIGHT, AND WIDTH.

PHYSICAL SOIL PROPERTY DATA AND SOIL CHEMISTRIES OF SAMPLES FROM RED LAKE, AZ, JEAN LAKE AND ROACH LAKE, NV, AND MESQUITE LAKE, CA, 3/21/92-3/24/92

FLUVIAL ORIGIN OF THE BEATTY SCARP, NYE COUNTY, NEVADA

CARBON DIOXIDE, METHANE, CARBON-14, CARBON 13/12, AND OXYGEN 18/16 GAS RESULTS FROM USW UZ-6, USW UZ-6S, USW UZ-N71, USW UZ-N72, USW UZ-N73, USW UZ-N74, USW UZ-N75, USW UZ-N76, USW UZ-N93, USW UZ-N94, AND USW UZ-N95 FOR MARCH 1993

1. TEMPERATURE DATA, DOWNHOLE, WELL USW UZ-6S FROM JANUARY 22, 1993 TO FEBRUARY 17, 1993; 2. BOREHOLE FLOW, DIRECTION, TEMPERATURE AND RELATIVE HUMIDITY DATA FROM WELL USW UZ-6S FROM MAY 25， 1993 TO OCTOBER 18, 1993

FAULT ATTITUDE DATA OF THE PAINTBRUSH CANYON FAULT SYSTEM 
GS940308314211.011 TABLE OF CONTACTS FOR THE TIVA CANYON TUFF IN BOREHOLE USW UZ-N38

GS940308314211.016 TABLE OF CONTACTS FOR THE TIVA CANYON TUFF IN BOREHOLE USW UZN-64, VERSION(S) 1.(N)

GS940308314211.017 TABLE OF CONTACTS FOR THE TIVA CANYON TUFF IN BOREHOLE UE-25 UZN\#63

GS940308314211.018 TABLE OF CONTACTS FOR THE TIVA CANYON TUFF IN BOREHOLE USW UZ-N36, VERSION(S) 1.(N)

GS940308314211.019 TABLE OF CONTACTS FOR THE TIVA CANYON TUFF IN BOREHOLES USW UZ-N15, USW UZ-N16, AND USW UZN17, VERSION(S) 1. (N)

GS940308314222.001 FRACTURE DATA FOR PAVEMENT ARP-1, 12/17$22 / 93,2 / 8-12 / 94$, AND 3/1/94

GS940608314211.022 LITHOSTRATIGRAPHIC DATA FOR THE PROW PASS TUFF IN USW G-1, G-2, GU-3, AND G-4, UE-25 C\#1, C\#2, AND C\#3, AND FIELD OBSERVATIONS FROM RAVEN CANYON AND PROS PASS

GS940608314211.024 LITHOSTRATIGRAPHIC DATA FOR THE PROW PASS TUFF IN USW UZ-14

GS940608314211.025 LITHOSTRATIGRAPHIC DATA FOR THE CALICO HILLS FORMATION IN USW G-1, G-2, GU-3, AND G-4, UE25 A\#1, UE-25 C\#1, C\#2, AND FIELD OBSERVATIONS FROM BUSTED BUTTE AND PROW PASS

GS940608314211.026 LITHOSTRATIGRAPHIC DATA FOR THE CALICO HILLS INFORMATION IN UE-25 UZ\#16. THESE DATA SUPERSEDE A PORTION OE THE DATA PREVIOUSLY IDENTIFIED BY DTN GS931208314211.047.

GS940608314211.027 IITHOSTRATIGRAPHIC DATA FOR THE CALICO HILLS FORMATION IN THE USW UZ-14

GS940608314222.002 CHARACTERIZING FRACTURED ROCK FOR FLUID-FLOW, GEOMECHANICAL, AND PALEOSTRESS MODELING: METHODS AND PRELIMINARY RESULTS FROM YUCCA MOUNTAIN, NEVADA 
GS940707312261.004

GS940708312212.010

GS940708312212.011

GS940708312261.005

GS940708312261.006

GS940708314211.034

GS940808314212.003

GS940908314211.043

GS940908314211.044
SHUT-IN PRESSURE TEST DATA FROM DECEMBER 1992 TO FEBRUARY 1994 FROM SELECT WELLS AND BOREHOLES AT YUCCA MOUNTAIN, NEVADA

VOLUMETRIC WATER CONTENT FROM NEUTRON MOISTURE METER COUNTS FOR 74 BOREHOLES FROM THE TIME THEY WERE DRILLED UNTIL 5/2/89

VOLIMETRIC WATER CONTENT FROM NEUTRON MOISTURE METER COUNTS FOR 99 BOREHOLES FROM 5/3/89 OR FROM THE TIME THEY WERE DRILLED UNTIL 12/31/93. THESE DATA SUPERSEDE DATA PREVIOUSLY IDENTIFIED BY DTN: GS930108313212.004; GS940108312212.005; AND GS940108312212.006.

CARBON DIOXIDE, METHANE, CARBON 13/12, AND OXYGEN 18/16 RESULTS FROM USW UZ-6, USW UZ6S, USW UZ-N27, USW UZ-N62, USW UZ-N64, USW UZ-N75, USW UZ-N93, USW UZ-N94, USW UZ-N95, UE-25 NRG\#2B，UE-25 NRG\#4, UE-25 NRG\#5, AND USW NRG-6. THESE DATA WERE COLLECTED IN JANUARY 1994 AND MARCH 1994.

BOREHOLE FLOW, DIRECTION, TEMPERATURE, AND RELATIVE HUMIDITY DATA FROM WELL USW UZ-6S FROM OCTOBER 22, 1993 TO MARCH 7, 1994

MISCELLANEOUS LITHOSTRATIGRAPHIC CONTACTS IN NON-QUALIFIED BOREHOLES (USW G-2 AND G-4, UE-25 A\#1), VERSION (S) 1. (N)

GHOST DANCE FAULT GRAVITY AND MAGNETIC DATA, SEPTEMBER 1993

TABLE OF LITHOLOGIC CONTACTS FROM THE BASE OF THE TONOPAH SPRING TUFF TO TOTAL DEPTH IN BOREHOLE USW UZ-14, VERSION(S) 1. (N) . THE CONTACT ALTITUDES FOR THE PROW PASS TUFF SUPERSEDE THOSE FOUND IN THE DATA SEGMENT PREVIOUSLY IDENTIFIED BY DTN GS940608314211.024.

TABLE OF LITHOLOGIC CONTACTS FOR THE PAINTBRUSH GROUP IN BOREHOLE USW SD-I2, $\operatorname{VERSION~(S)~1.~(N)~}$ 
GS940908315213.002

TH ISOTOPIC DATA AND U-SERIES

DISEQUILIBRIUM DATING OF SPRING DISCHARGE DEPOSITS NEAR THE SOUTHERN END OF CRATER FLAT. DATA INCLUDE SAMPLE PREPARATION DESCRIPTIONS, ALPHA SPECTROMETRIC RESULTS, MASS SPECTROMETRIC RESULTS, A SUMMARY OF ISOTOPIC DATA INCLUDING THE PERTINENT RATIOS, ERRORS AND ERROR CORRELATIONS OF THE ISOTOPES OF INTEREST (238U, 236U, 234U, 232TH, 23OTH)

GS940908315213.003 RADIOCARBON DATE BY ACCELERATOR MASS SPECTROMETRY OF INORGANIC CARBON FROM A CALCIFIED RHIZOLITH: PALEOSPRING DEPOSITS, SOUTHERN END OF CRATER FLAT

GS941008312212.013

NEUTRON COUNTS FOR 97 BOREHOLES AT YUCCA MOUNTAIN FROM JANUARY 1, 1994 TO OCTOBER 1, 1994

GS941008314211.050

TABLE OF LITHOLOGIC CONTACTS IN BOREHOLE USW SD-9 FROM THE BASE OF THE PAINTBRUSH GROUP TO TOTAL DEPTH, VERSION(S) I(N)

GS941108312132.003 HEAT-PULSE FLOWMETER SURVEY DATA FROM WELL USW G-2

GS941108319211.002

LEAD ISOTOPE RATIOS AND ISOTOPE DILUTION DATA FOR URANIUM, THORIUM, AND LEAD, APRIL TO JULY 1994

GS941108319211.003

OXYGEN ISOTOPE DATA ON TIVA CANYON TUFF FROM ANTLER RIDGE

GS941208312212.017

SUBSURFACE WATER CONTENT AT YUCCA MOUNTAIN NEVADA - NEUTRON LOGGING DATA FOR 1/1/94 THROUGH FY94

GS941208312261.008

CARBON DIOXIDE, METHANE, CARBON 14, AND CARBON 13/12 DATA USW NRG-6 AND USW NRG-7 FOR MAY AND JUNE 1994; AND CARBON 14 DATA FROM USW WELLS NRG\#5, UZ-6S, UZ-N27, UZ-N62, UZN64, UZ-N93, UZ-N94, AND UZ-N95 FROM MARCH 1994

GS941208315213.010

PHYSICAL SOIL PROPERTY DATA FROM PLAYA SAMPLES COLLECTED ON 5/21/91 AT FRANKLIN LAKE PLAYA 


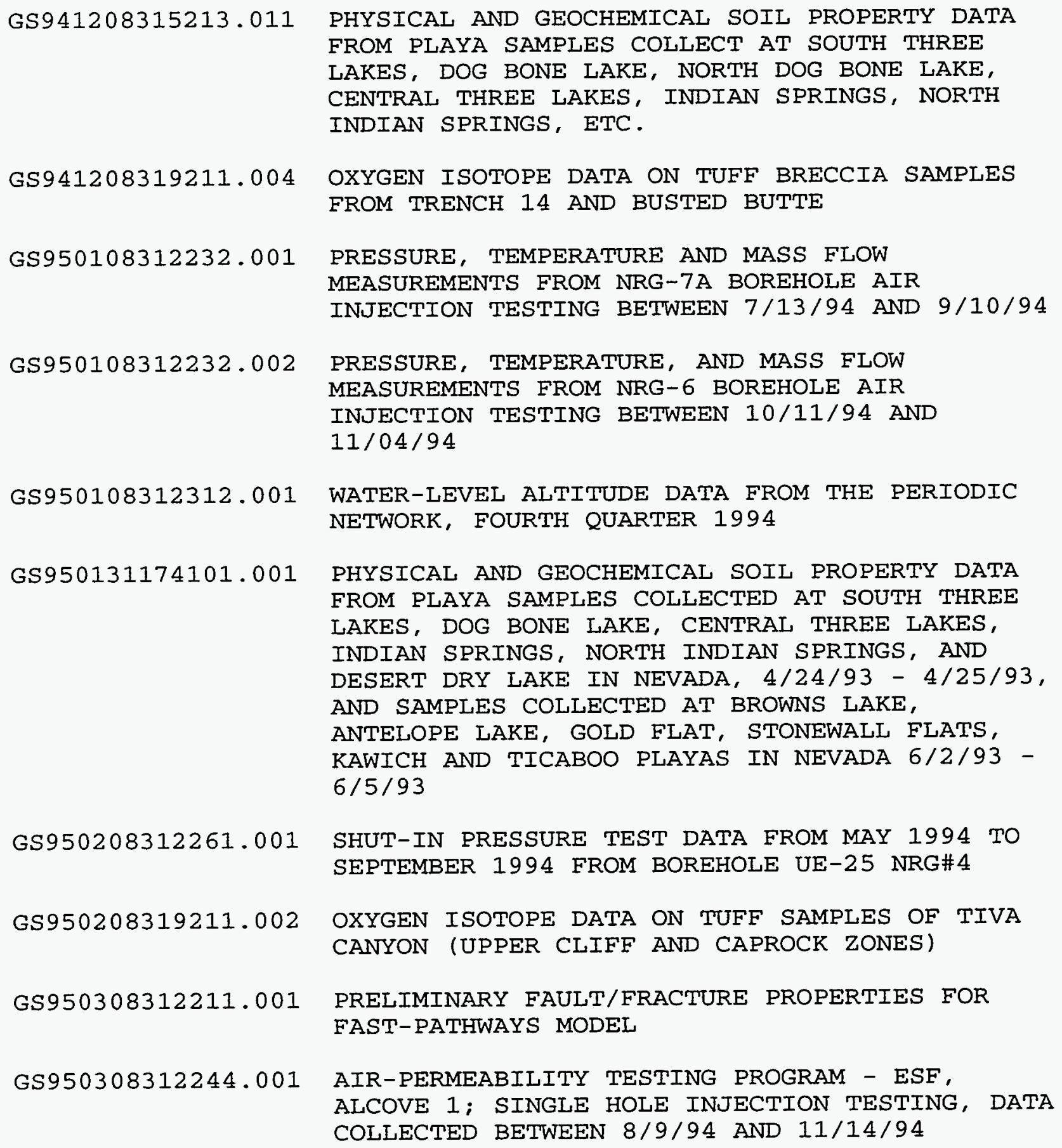


GS950308314211.015 ASSESSING THE NATURAL PERFORMANCE OF FELSIC TUFFS USING THE RB-SR AND SM-ND SYSTEMS - A STUDY OF THE ALTERED ZONE IN THE TOPOPAH SPRING MEMBER, PAINTBRUSH TUFF, YUCCA MOUNTAIN. THESE DATA SUPERSEDE DATA PREVIOUSLY IDENTIFIED BY DTN GS931108315215.032 AND GS910708314211.011

GS950308319211.007 ACTIVATION LABORATORIES INAA ELEMENTAL ANALYSES OF DRILL CORE SAMPLES FROM USW G-2

GS950308319213.001

PREVIOUSLY UNPUBLISHED DOWNHOLE TEMPERATURE DATA FOR WELLS NEAR OR AT YUCCA MOUNTAIN, NV - LOGGED FROM MAY 179 TO DEC. '81. DATA ARE THE LOGGED TEMPERATURES, MINIMUM AND MAXIMUM, OF THE BOREHOLE

GS950308319213.002

PREVIOUSLY UNPUBLISHED DOWNHOLE TEMPERATURE DATA FOR WELLS NEAR OR AT YUCCA MOUNTAIN, NV - LOGGED FROM JAN. ' 82 TO SEPT. ' 85 . DATA ARE THE LOGGED TEMPERATURES, MINIMUM AND MAXIMUM, OF THE BOREHOILE

GS950331174102.001

GLOBAL POSITIONING SYSTEM PROFILE: YUCCA MOUNTAIN TO SIERRA NEVADA

GS950408318523.001

TEMPERATURE AND THERMAI CONDUCTIVITY IN WELLS NEAR YUCCA MOUNTAIN, NEVADA; SOME TECTONIC AND HYDROLOGIC IMPLICATIONS

GS950508312333.002 BOREHOLE DATA FOR HYDROGEOLOGIC FRAMEWORK MODEL CONSTRUCTION. THE FIRST TOP ENCOUNTERED FOR EACH HYDROGEOLOGIC UNIT IS REPRESENTED.

LA000000000033.002

MEASURED SOLUBILITIES AND SPECIATIONS FROM OVERSATURATION EXPERIMENTS OF NEPTUNIUM, PLUTONIUM, AND AMERICIUM IN UE25P\#1 WELL WATER FROM THE YUCCA MOUNTAIN PROJECT

LLLLYMP9110169.000 RATE OF GRAIN VOLUME FRONT PROPAGATION UO(2) TO U(4)O(9) AND ACTIVATION ENERGY FOR THIS RATE

LLLLYMP9109192 . 000

DISSOLUTION AND PRECIPITATION KINETICS OF GIBBSITE AT 80 DEGREES C AND PH3: THE DEPENDENCE ON SOLUTION SATURATION STATE 
LL950103004244.004

SNF2 9041993002.053

SNF2 9041993002.056

SNF29041993002.059

TM000000000001.062

TM0000000SD9RS.001

TM0000000SD9RS.002

TM0000000SD9RS.003

TM000000SD12RP.001
A PROGRESS REPORT FOR THE LARGE BLOCK TEST OF THE COUPLED THERMAL-MECHANICAL-HYDROLOGICALCHEMICAL PROCESSES

YUCCA MOUNTAIN SITE CHARACTERIZATION PROJECT ESTIMATED ROCK MASS QUALITY INDICES BASED ON CORE LOG DATA FOR HOLE USW SD-9, MIDDLE NONLITHOPHYSAI ZONE, REV. 0

YUCCA MOUNTAIN SITE CHARACTERIZATION PROJECT ROCK MASS QUALITY INDICES BASED ON CORE LOG DATA FOR HOLE USW SD-12, MIDDLE NONLITHOPHYSAL ZONE, REV. 0

YUCCA MOUNTAIN SITE CHARACTERIZATION PROJECT COMPARISON OF DOWNHOLE VIDEO DATA WITH CORE DATA FOR HOLE UE25 NRG-4, -5, USW NRG-6, 7/7A, REV . 0

ORIGINAL SOURCE DATA AND HARDCOPY BACKUP DATA FOR: ATMOSPHERIC PRESSURE, PRECIPITATION, RELATIVE HUMIDITY, TEMPERATURE, WIND DIRECTION, AND WIND SPEED

SHIFT DRILLING SUMMARIES FOR USW SD-9 (YMP012) FROM 7.4' TO 1489.2'; STRUCTURAL LOGS (YMP-001) FROM 53.6' TO 1488.0'; AND LITHOLOGIC LOGS (YMP-009) FROM 0.0' TO $1450.0^{\prime}$

USW SD-9 SHIFT DRILLING SUMMARIES, STRUCTURAL LOGS, AND LITHOLOGIC LOGS FROM APPROXIMATELY $145.0^{\prime}$ 'TO $1690.6^{\prime}$

USW SD-9 SHIFT DRILLING SUMMARIES, STRUCTURAL LOGS, AND LITHOLOGIC LOGS FROM APPROXIMATELY 1665' TO $2030.6^{\prime}$

USW SD-12 BOREHOLE SAMPLE COLLECTING AND PROCESSING INFORMATION: SHIFT DRILLING SUMMARIES (YMP-012-R2); STRUCTURAL LOGS (YMP011-R4); LITHOLOGIC LOGS (YMP-009-R4) 
TM000000SD12RP.002

TM000000SD12RP.003

TM000000SD12RP.004

TM0 00000 SD12RP.005

TM000000SD12RS.008

TM00121362T1DA.001
USW SD-12 BOREHOLE SAMPLE COLLECTING AND PROCESSING INFORMATION FOR THIS RECORDS/DATA SEGMENT IS FROM 540.7 TO 600.7 FEET AND IS RECORDED ON THE FOLLOWING DOCUMENTS: SHIFT DRILLING SUMMARIES (YMP-012-R2); STRUCTURAL LOGS (YMP-011-R4); LITHOLOGIC LOGS (YMP-009R4)

USW SD-12 BOREHOLE SAMPLE COLLECTING AND PROCESSING INFORMATION FOR THIS RECORDS/DATA SEGMENT IS FROM 600.7 FEET TO 660.7 FEET AND IS RECORDED ON THE FOLLOWING DOCUMENTS: SHIFT DRILLING SUMMARIES (YMP-012-R2); STRUCTURAL LOGS (YMP-001-R4); LITHOLOGIC LOGS (YMP-009)

USW SD-12 BOREHOLE SAMPLE COLLECTING AND PROCESSING INFORMATION FOR THIS RECORDS/DATA SEGMENT IS RECORDED ON THE FOLLOWING DOCUMENTS: SHIFT DRILLING SUMMARIES (YMP012-R2)，600.7' TO 700.8'; STRUCTURAL LOGS (YMP-001-R4)，667.9, TO 699.7'; AND LITHOLOGIC LOG (YMP-009-R4), 650.0' TO 675.0'

USW SD-12 BOREHOLE SAMPLE COLLECTING AND PROCESSING INFORMATION FOR THIS RECORDS/DATA SEGMENT IS RECORDED ON THE FOLLOWING DOCUMENTS: SHIFT DRILLING SUMMARIES (YMP012-R2)，700.8-703.9; - STRUCTURAL LOGS (YMP001-R4), 699.5-714.9; AND - LITHOLOGIC LOGS (YMP-009-R4), 675.0 TO 725.0

TM000000SD12RS.006 SHIFT DRILLING SUMMARIES FOR USW SD-12 (YMP012) FROM 0.0-300.8; STRUCTURAL LOGS (YMP001) FROM 53.0-295.8; AND LITHOLOGIC LOGS (YMP-009) FROM 0.0-278.3

USW SD-12 SHIFT DRILLING SUMMARIES, LITHOLOGIC LOGS, AND STRUCTURAL LOGS

YUCCA MOUNTAIN SITE CHARACTERIZATION PROJECT SUMMARY OF THE SOCIOECONOMIC DATA ANALYSES CONDUCTED IN SUPPORT OF THE RADIOLOGICAL MONITORING PROGRAM DURING CALENDAR YEAR 1992 (MAY 1993) 
DATA TRACKING NO. TM00012562T1BA. 001

TM00012562T1BA. 003

TM00012562T1BA.004

TM00012562TIBA.006

TM00121362T1EA.001

TM00121361T1EC.001

TMBH-VARIOUS95.001
DATA ITEM DESCRIPTION

YUCCA MOUNTAIN SITE CHARACTERIZATION PROJECT SUMMARY OF SOCIOECONOMIC DATA ANALYSES CONDUCTED IN SUPPORT OF THE RADIOLOGICAL MONITORING PROGRAM DURING FY 1989

YUCCA MOUNTAIN SITE CHARACTERIZATION PROJECT SUMMARY OF THE SOCIOECONOMIC DATA ANALYSES CONDUCTED IN SUPPORT OF THE RADIOLOGICAL MONITORING PROGRAM DURING FY 1990

YUCCA MOUNTAIN SITE CHARACTERIZATION PROJECT SUMMARY OF THE SOCIOECONOMIC DATA ANALYSES CONDUCTED IN SUPPORT OF THE RADIOLOGICAL MONITORING PROGRAM DURING CALENDAR YEAR 1990

YUCCA MOUNTAIN SITE CHARACTERIZATION PROJECT SUMMARY OF THE SOCIOECONOMIC DATA ANALYSES CONDUCTED IN SUPPORT OF THE RADIOLOGICAL MONITORING PROGRAM DURING CALENDAR YEAR 1991

YUCCA MOUNTAIN SITE CHARACTERIZATION PROJECT SUMMARY OF SOCIOECONOMIC DATA ANALYSES CONDUCTED IN SUPPORT OF THE RADIOLOGICAL MONITORING PROGRAM DURING CALENDAR YEAR 1993 (JUNE 1994)

YUCCA MOUNTAIN SITE CHARACTERIZATION PROJECT SOCIOECONOMIC MONITORING PROGRAM QUARTERLY EMPLOYMENT DATA REPORT, OCTOBER 1994 THROUGH DECEMBER 1994

DIRECTIONAL/DEVIATION GYRO SURVEYS OF THE FOLLOWING BOREHOLES: UE-25 NRG-2, UE-25 NRG$2 A$ ，UE-25 NRG-2B，UE-25 NRG-2D，UE-25 NRG-3, UE-25 NRG-4, UE-25 NRG-5, USW NRG-6, USW NRG7/7A, USW WT-2, UE-25, UE-16, AND USW UZ-1 
APPENDIX C

SUPERSEDING DATA ITEMS

DTN

GS940708312212.011

GS930708314211.031

GS940608314211.026

GS950108314211.007

GS950108314211.008
SOPERSEDED DTN

GS940108312212.005

GS930108312212.004 GS940108312212.006

GS900908312232.001

GS931208314211.047

GS930208314211.008 GS900908314213.002

GS940208314211.005 GS941008314211.049 GS931208314211.047 GS940608314211.023 GS931108314211.041 GS940208314211.003

\section{CHANGE DESCRIPTION}

Updates equation for calculating volumetric water content

Converts data measurements to metric in Lithologic Log, Table 3

corrects contact altitude calculation

Changes to some lithologic contacts, descriptions, and stratigraphic nomenclature

Changes to some lithologic contacts, descriptions, and stratigraphic nomenclature

* Indicates superseding data items added during the current quarter. 
GS950108314211.010

GS950108314211.011

GS950108314211.009

\section{SUPERSEDED DTN}

GS931108314211.042 GS941108314211.055 GS940108314211.001 GS940308314211.014 GS940408314211.020 GS931208314211.048 GS940208314211.005 GS941008314211.051 GS941008314211.049 GS931208314211.047 GS940208314211.003 GS941208314211.060 GS940308314211.009 GS940708314211.032 GS931208314211.049

GS900908314213.002 GS900908314213.010 GS930208314211.008 GS920908314211.003 GS920908314211.002

GS931108314211.041 GS940108314211.001 GS940308314211.014 GS940408314211.020 GS931208314211.048 GS931208314211.047 GS940308314211.010 GS940208314211.006 GS940208314211.003 GS941208314211.060 GS940308314211.009 GS940708314211.032

\section{CHANGE DESCRIPTION}

Changes to some lithologic contacts, descriptions, and stratigraphic nomenclature

Changes to some lithologic contacts, descriptions, and stratigraphic nomenclature

Changes to some lithologic contacts, descriptions, and stratigraphic nomenclature 
${ }^{*}$ GS950508312134.001

*GS950308314211.015

*GS950608314211.024

SNT01122093001.002

SNF29041993002.021

SNL01B05059301.003
GS931208314211.047

GS931208314211.047

GS940608314211.024

GS900908314213.002 GS900908314213.010 GS930208314211.008 GS920908314211.003

GS910408312141.001

GS910708314211.011 GS931108315215.032

GS940908314211.043

SNT01122093001.001

SNF2 9041993002.013

SNL01B05059301.002

\section{CHANGE DESCRIPTION}

Changes to some lithologic contacts, descriptions, and stratigraphic nomenclature

Changes to some lithologic contacts, descriptions, and stratigraphic nomenclature

Changes to some lithologic contacts, descriptions, and stratigraphic nomenclature

Changes to some lithologic contacts; descriptions, and stratigraphic nomenclature

Corrections to wind speed and evapotranspiration data

Deletion of suspect data in Table II of the report

Corrects error in contact between Units 2 and 3 of the Prow Pass Tuff

Includes additional data

Includes additional data

Converts digital data to graphical format 


\section{DTN}

SNL01A05059301.002

SNF29041993002.030

SNF2 9041993002.031

SNF29041993002.032

SNT02052794001.002

SNF29041993002.034

SNF29041993002.035

SNF29041993002.036

SNE29041993002.037

SNF29041993002.038

SNF29041993002.039

SNF29041993002.040

\section{SUPERSEDED DTN}

SNL01A05059301.001

SNF29041993002.011

SNF29041993002.012

SNF29041993002.020

SNT02052794001.001

SNF29041993002.003

SNE29041993002.001

SNF29041993002.004

SNF29041993002.014

SNF2 9041993002.005

SNF2 9041993002.008

SNF29041993002.007

\section{CHANGE DESCRIPTION}

Additional data based on expanded sample size

Includes additional data

Includes additional data

Includes additional data

Includes additional data

Revised to include USGS nomenclature and change in calculation method

Revised to include USGS nomenclature and change in calculation method

Revised to include USGS nomenclature and change in calculation method

Revised to include USGS nomenclature and change in calculation method

Revised to include USGS nomenclature and change in calculation method

Revised to include USGS nomenclature and change in calculation method

Revised to include USGS nomenclature and change in calculation method 
DTN

SNF29041993002.041

SNF29041993002.042

SNF2 9041993002.043

SNF29041993002.044

SNF2 9041993002.047

SNF29041993002.048

SNF2 9041993002.049

SNF29041993002.050

*SNT02052794001.002

TM000019921993.001

*TM0000 SD9 SUPER . 001
SNF29041993002.006

SNF2 9041993002.015

SNF29041993002.025

SNF29041993002.021

SNF2 9041993002.011 SNF29041993002.017 SNF2 9041993002.019

SNF2 9041993002.009 SNF29041993002.016 SNF2 9041993002.018

SNF29041993002.031

SNF29041993002.032

SNT02052794001.001

TM000019911992.001

TM0000000SD9RS.003

\section{CHANGE DESCRIPTION}

Revised to include USGS nomenclature and change in calculation method

Includes additional data, revised survey coordinates and elevations, and change in calculation method

Includes additional data

Includes additional data

Includes change in calculation method and revisions to stratigraphy

Includes change in calculation method, USGA nomenclature, and stratigraphy revisions and additional data

Changes $Q$ values for PTN units

Changes $Q$ values for PTN units

Revised and expanded geologic logs

Additional biota data for 1992 and 1993

Recalculations of values and descriptions on lithologic log (P.71) 
A. B. Brownskin, HQ $(R W-36)$ FORS

R. A. Milner, HQ (RW-30) FORS

C. E. Einberg, HQ (RW-36) FORS

Samuel Rousso, HQ (RW-40) FORS

Antanas Bindokas, $\mathrm{CH}$

Mark Delligatti, NRC, Washington, DC (8)

W. L. Belke, NRC, Las Vegas, NV (2)

W. D. Barnard, NWTRB, Arlington, VA

R. R. Loux, State of Nevada, Carson City, NV (2)

Cyril Schank, Churchill County, Fallon, NV

D. A. Bechtel, Clark County, Las Vegas, NV

J. D. Hoffman, Esmeralda County, Goldfield, NV

Eureka County Board of Commissioners, Eureka, NV

B. R. Mettam, Inyo County, Independence, CA

Lander County Board of Commissioners, Battle Mountain, NV

Jason Pitts, Lincoln County, Pioche, NV

V. E. Poe, Mineral County, Hawthorne, NV

L. W. Bradshaw, Nye County, Tonopah, NV

Florindo Mariani, White Pine County, Ely, NV

P. A. Niedzielski-Eichner, Nye County, Chantilly, VA

William Offutt, Nye County, Tonopah, NV

William Hinze, Purdue University, West Lafayette, IN

J. N. Brune, UNR, Reno, NV

J. A. Epps, UNR, Reno, NV

James Hendrix, UNR, Reno, NV

D. H. Von Seggern, UNR, Reno, NV

Klaus Stetzenbach, UNLV, Las Vegas, NV

D. L. Weide, UNLV, Las Vegas, NV

W. R. Wells, UNLV, Las Vegas, NV

Lloyd Levy, Planning Information Corporation, Denver, CO

F. H. Swan, Geomatrix, San Francisco, CA

Benjamin Ross, DSI, Washington, DC

C. E. Russell, DRI, Las Vegas, NV

P. E. Wigand, DRI, Reno, NV

C. E. Ezra, EG\&G/EM, Las Vegas, NV

D. T. Purvance, IT Corporation, Las Vegas, NV

J. A. Canepa, LANL, Los Alamos, NM

J. T. Fabryka-Martin, LANL, Los Alamos, NM

Carl Gable, LANL, Los Alamos, NM

B. A. Robinson, LANL, LOS Alamos, NM

Sid Weaver, LANL, Los Alamos, NM

M. E. Herrera, LANL, Los Alamos, NM

B. M. Crowe, LANL, Las Vegas, NV

N. Z. Elkins, LANL, Las Vegas, NV

R. D. Oliver, LANL, Las Vegas, NV

D. C. Guerin, LATA, Albuquerque, NM

G. S. Bodvarsson, LBL, Berkeley, CA

T. N. Narasimhan, LBL, Berkeley, CA

Karsten Preuss, LBL, Berkeley, CA

Chin-Fu Tsang, LBL, Berkeley, CA

J. S. Wang, LBL, Berkeley, CA

E. F. Campbell, LLNL, Livermore, CA 
W. L. Clarke, LLNL, Livermore, CA (3)

J. W. Johnson, LLNL, Livermore, CA

M. A. Revelli, LLNL, Livermore, CA

J. A. Blink, LLNL, Las Vegas, NV

P. W. Eslinger, PNL, Richland, WA

W. C. Kopatich, RSN, Las Vegas, NV

G. W. Heitland, SAIC, Golden, CO

T. A. Grant, M\&O/SAIC, Las Vegas, NV

J. A. Hartley, M\&O/SAIC, Las Vegas, NV

D. Y. Hattler, M\&O/SAIC, Las Vegas, NV

L. S. Linden, M\&O/SAIC, Las Vegas, NV

S. K. Majewski, M\&O/SAIC, Las Vegas, NV

C. A. Matthews, M\&O/SAIC, Las Vegas, NV

K. J. Shenk, M\&O/SAIC, Las Vegas, NV

J. K. Statler, M\&O/SAIC, Las Vegas, NV

L. E. Thompson, M\&O/SAIC, Las Vegas, NV

Reference Center, M\&O/SAIC, Las Vegas, NV Gerard Heaney, QATSS, Las Vegas, NV

L. S. Costin, SNL, Albuquerque, NM, M/S 1325

S. A. Edmund, SNL, Albuquerque, NM, M/S 1330

Eloise James, SNL, Albuquerque, NM, M/S 1330

M. L. Jones, SNL, Albuquerque, NM, M/S 1343

R. P. Sandoval, SNL, 6641, Albuquerque, NM, M/S 0726

L. E. Shephard, SNL, Albuquerque, NM, M/S 1333

C. M. Steele, SNL, Albuquerque, NM, M/S 1343

Peggy Warner, SNL, Albuquerque, NM, M/S 1330

D. I. Eley, SNL, Albuquerque, NM, M/S 1343

J. E. Grant, SNL, Mercury, NV, M/S 714

D. S. Kessel, SNL, Las Vegas, NV

H. A. Benton, $M \& O / B \& W$, Las Vegas, NV

T. M. Williamson, M\&O/Duke, Las Vegas, NV

P. A. Pimentel, M\&O/Fluor, Las Vegas, NV

R. W. Andrews, M\&O/INTERA, Vienna, VA

R. W. Nelson, M\&O/INTERA, Las Vegas, NV

D. C. Sassani, M\&O/INTERA, Las Vegas, NV

A. E. Van Luik, M\&O/INTERA, Las Vegas, NV

P. M. Dunn, M\&O/TRW, Vienna, VA

S. J. Bodnar, M\&O/TRW, Las Vegas, NV

I. D. Foust, M\&O/TRW, Las Vegas, NV

N. O. Jones, M\&O/TRW, Las Vegas, NV

R. F. Lewis, M\&O/TRW, Las Vegas, NV

Scott Sinnock, M\&O/TRW, Las Vegas, NV

H. C. Stafford, M\&O/TRW, Las Vegas, NV

R. N. Datta, M\&O/WCC, Las Vegas, NV

S. T. Nelson, M\&O/WCC, Las Vegas, NV

C. T. Statton, M\&O/WCC, Las Vegas, NV

P. W. McKie, $M \& O / M-K$, Las Vegas, NV

K. K. Bhattacharyya, $M \& O / M-K$, Las Vegas, NV

J. L. Naaf, M\&O/M-K, Las Vegas, NV

M. J. Dorsey, REECo, Las Vegas, NV

D. L. Koss, REECO, Las Vegas, NV

J. A. Krulik, USBR, Denver, CO

A. L. Flint, USGS, Mercury, NV, M/S 721

Timothy Libermann, USGS, Carson City, NV 
H. W. Oliver, USGS, Menlo Park, CA

D. H. Appel, USGS, Denver, CO

M. S. Boucher, USGS, Denver, CO

M. P. Chornack, USGS, Denver, CO

R. M. Forester, USGS, Denver, CO

D. C. Gillies, USGS, Denver, CO

P. L. Hennessy, USGS, Denver, CO

K. A. Larsen, USGS, Denver, CO

R. R. Luckey, USGS, Denver, CO

P. W. McKinley, USGS, Denver, CO

T. M. Mendez-Vigo, USGS, Denver, CO

Z. E. Peterman, USGS, Denver, CO

R. W. Spengler, USGS, Denver, CO

J. S. Stuckless, USGS, Denver, CO

James Watson, USGS, Denver, CO

J. W. Whitney, USGS, Denver, CO

J. B. Woolverton, USGS, Denver, CO

D. A. Beck, USGS, Las Vegas, NV

D. C. Buesch, USGS, Las Vegas, NV

R. W. Craig, USGS, Las Vegas, NV

L. R. Hayes, USGS, Las Vegas, NV

D. T. Hoxie, USGS, Las Vegas, NV

D. W. Duncan, AMEM, NV

W. E. Barnes, YMSCO, NV

T. W. Bjerstedt, YMSCO, NV

S. J. Brocoum, YMSCO, NV (2)

R. L. Craun, YMSCO, NV

W. R. Dixon, YMSCO, NV

J. R. Dyer, YMSCO, NV

T. I. Fortner, YMSCO, NV

S. B. Jones, YMSCO, NV

R. E. Spence, YMQAD, NV

D. R. Williams, YMSCO, NV 